

\section{COMMONWEALTH HUMAN RIGHTS INITIATIVE}

The Commonwealth Human Rights Initiative (CHRI) is an independent, non-partisan, international non-governmental organisation, mandated to ensure the practical realisation of human rights in the countries of the Commonwealth. In 1987, several Commonwealth professional associations founded CHRI. They believed that while the Commonwealth provided member countries a shared set of values and legal principles from which to work and provided a forum within which to promote human rights, there was little focus on the issues of human rights within the Commonwealth.

The objectives of CHRI are to promote awareness of and adherence to the Commonwealth Harare Principles, the Universal Declaration of Human Rights and other internationally recognised human rights instruments, as well as domestic instruments supporting human rights in Commonwealth member states.

Through its reports and periodic investigations, CHRI continually draws attention to progress and setbacks to human rights in Commonwealth countries. In advocating for approaches and measures to prevent human rights abuses, CHRI addresses the Commonwealth Secretariat, member governments and civil society associations. Through its public education programmes, policy dialogues, comparative research, advocacy and networking, CHRI's approach throughout is to act as a catalyst around its priority issues.

The nature of CHRI's sponsoring organisations allows for a national presence and an international network. ${ }^{*}$ These professionals can also steer public policy by incorporating human rights norms into their own work and act as a conduit to disseminate human rights information, standards and practices. These groups also bring local knowledge, can access policy makers, highlight issues, and act in concert to promote human rights.

CHRI is based in New Delhi, India, and has offices in London, UK, and Accra, Ghana.

*International Advisory Commission: Sam Okudzeto - Chairperson. Members: Eunice Brookman-Amissah, Murray Burt, Jean Corston, Alison Duxbury, Neville Linton, B.G. Verghese, Zohra Yusuf and Maja Daruwala.

Executive Committee (India): B.G. Verghese-Chairperson. Members: Anu Aga, B.K.Chandrashekar, Bhagwan Das, Nitin Desai, K.S. Dhillon, Harivansh, Sanjoy Hazarika, Poonam Muttreja, Ruma Pal, R.V. Pillai, Mool Chand Sharma and Maja Daruwala-Director

Executive Committee (Ghana): Sam Okudzeto-Chairperson. Members: Anna Bossman, B.G. Verghese and Maja Daruwala - Director

Executive Committee (UK): Neville Linton - Chairperson. Members: Austin Davis, Meenakshi Dhar, Derek Ingram, Claire Martin, Lindsay Ross, Elizabeth Smith.

*Commonwealth Journalists Association, Commonwealth Lawyers Association, Commonwealth Legal Education Association, Commonwealth Parliamentary Association, Commonwealth Press Union and Commonwealth Broadcasting Association.

ISBN: $81-88205-47-8$

(c) Commonwealth Human Rights Initiative, 2007.

Material from this report may be used, duly acknowledging the source.

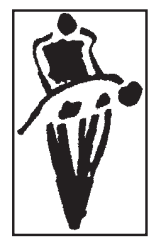

\section{COMMONWEALTH HUMAN RIGHTS INITIATIVE}

CHRI New Delhi Office (Headquarters)

B-117, Second Floor, Sarvodaya Enclave

New Delhi - 110 017, INDIA

Tel: +91-11-2685-0523, 2652-8152, 2686-4678

Fax: +91-11-2686-4688

E-mail: chriall@nda.vsnl.net.in
CHRI London Office

Institute of Commonwealth Studies

28, Russell Square

London WC1B 5DS, UK

Tel: +44-020-7-862-8857

Fax: +44-020-7-862-8820

E-mail: chri@sas.ac.uk
CHRI Africa Office

House No.9,

Samora Machel Street Asylum Down, opposite Beverly Hills Hotel,

Near Trust Towers, Accra, Ghana

Tel/Fax: +00233-21-271170

E-mail: chriafr@africaonline.com.gh

Website: www.humanrightsinitiative.org 


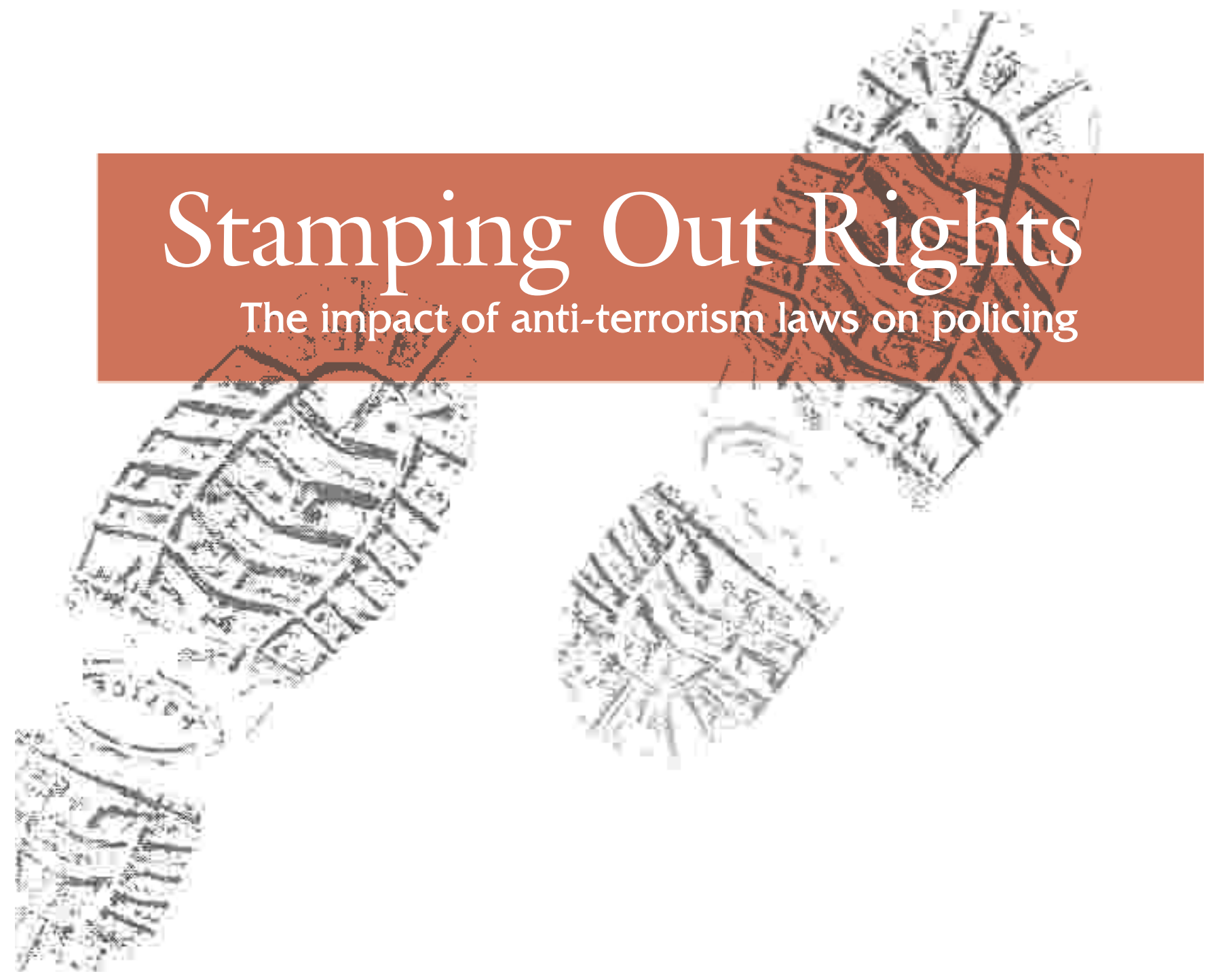

The 2007 report by the International Advisory Commission of the Commonwealth Human Rights Initiative, Chaired by Sam Okudzeto

Edited by Maja Daruwala \& Tessa Boyd-Caine

Project co-ordination and head of research \& writing team: Tessa Boyd-Caine

Research \& writing team: Arnaud Chaltin, Gudrun Dewey, Manjiri Dube, Sophie Earnshaw \& Devika Prasad

Published by

Commonwealth Human Rights Initiative

B-117, First Floor, Sarvodaya Enclave,

New Delhi- 110017, INDIA

Designed and printed by

Multiplexus (India)

C-440, DSIDC, Narela Indl. Park, Narela,

Delhi-110040, INDIA

Cover inspired by URBAN PHUNK, Kenya

Chapter two title image used by permission of Commonwealth Secretariat 


\section{MEMBERS OF THE CHRI INTERNATIONAL ADVISORY COMMISSION}

Sam Okudzeto is Chair of CHRI's International Advisory Commission and a member of the Commonwealth Lawyers Association. He is a member of the Board of International Bar Association and also a member of the Bank of Ghana Board and Chairman of the University of Ghana College of Health Sciences Council. He has also been a member of the Prisons Service Council, General Legal Council and the Judicial Council, Chairman of the Public Accounts and Judicial Sub Committee of the Parliament of Ghana, and President of the Ghana Bar Association.

B.G. Verghese is Chair of CHRI India's Executive Committee and formerly associated with the Commonwealth Journalist Association (CJA). A columnist and author, he is a former Information Advisor to the Prime Minister of India, former editor of Hindustan Times and Indian Express, member of several official commissions and committees on water, security, the media, the Northeast and served on the boards of a number of public sector enterprises.

Dr. Neville Linton is Chair of CHRI United Kingdom's Executive Committee. He is a Consultant in Political Affairs, specialises in Democratisation and Human Rights issues in transition societies. Previously he was an academic (International Relations) at the University of West Indies-St Augustine, before serving as a senior official at the Commonwealth Secretariat. Currently he is a Senior Adviser with Transparency International and Tiri, consulting on corruption issues, particularly in Africa and the Caribbean.

Eunice Brookman-Amissah is a former Minister of Health in Ghana and former Ambassador to the Netherlands. She has been associated with the Commonwealth Medical Association in her capacity as Vice-President of the Ghana Medical Association. She has been active in women's rights for many years and is currently Vice-President of IPAS in Africa.

Murray Burt is the immediate past president of the Commonwealth Journalists Association. He is a former City and National Editor of The Globe and Mail in Toronto, and a former Managing Editor of the Winnipeg Free Press. He is on the Board of Governors of the National Newspaper Awards in Canada and a past president and life member of the Canadian Association of Newspaper Editors.

Jean Corston has been a Member of Parliament in the UK since 1992 and since then has been a member of a number of select committees and Chair of the Joint Committee on Human Rights since 2001. She has been a member of the Executive Committee of the Commonwealth Parliamentary Association (UK Branch) and British-Irish Inter-Parliamentary Body, Chair of the Parliamentary Labour Party and a former Chair to the Commonwealth Women Parliamentarians.

Alison Duxbury is a Senior Lecturer at the Law School of the University of Melbourne where she teaches International Humanitarian Law and Constitutional and Administrative Law. She is a member of the Advisory Board of the Melbourne Journal of International Law; the International Humanitarian Law Advisory Committee, Australian Red Cross (Vic); the Asia Pacific Centre for Military Law; and the Australian and New Zealand Society of International Law.

Zohra Yusuf is a writer and editor on media and human rights issues. She has been a Council Member of the Human Rights Commission of Pakistan since 1990, was Vice-Chairperson (Sindh Chapter) from 1990-1993 and Secretary-General for two terms. She is also a Collective Member of Shirkatgah Women's Resource Center, a founding member of Women's Action Forum and a member of the Steering Committee of Aga Khan Foundation's NGO Resource Centre.

Maja Daruwala is Executive Director of CHRI and is a barrister actively advocating for human rights. She is on the board of Civicus, Open Society Justice Initiative, International Women's Health Coalition, South Asians for Human Rights, Voluntary Action Network of India and Chairperson, Multiple Action Research Group. 


\section{FOREWORD}

Every two years the Commonwealth Human Rights Initiative (CHRI) reports on a particular issue affecting human rights in the Commonwealth. This year's report to the Commonwealth heads of government looks at the impact of anti-terrorism legislation on civilian policing. This continues CHRI's focus on policing in the Commonwealth and particularly highlights the need for police reform and greater police accountability.

Terrorism, in its various forms of organised violence against the state and against the civilian population, has a long history. What has changed is the response to it. Once restricted within national borders, terrorism has now been labelled a global phenomenon and there is tremendous international pressure from powerful states and institutions to respond to it through law, policy and measures on the ground. The sub-text is that it does not matter how it is done provided the menace of terrorism is eliminated. That menace itself is seen only in terms of the violence and havoc that attacks can wreak and not as the insidious ways in which state responses can in fact encourage and abet the cause of terrorists.

By its very nature terrorism is grounded in the notion of lawlessness while the validity of the state is founded on the rule of law, ability to safeguard people against every kind of depredation and ensure justice for all.

CHRI believes that the best and indeed the only way to fight terrorism is to ensure the rule of law, civil liberties, access to justice, people's participation in governance and better governance based on accountability, transparency and the celebration of diversity. CHRI contends that these values and human rights cannot be sacrificed in the name of security. CHRI is concerned that across the Commonwealth political expediency and the need to be seen doing something to fight terrorism - however ineffectual the reality of that course - is increasing disrespect for established international norms of state behaviour and consequently providing aid and succour to the terrorists' cause.

Countering terrorism requires many simultaneous responses to be actioned at different levels. Law enforcement agencies are in the front line of this and none more so than the civilian police force. Effective counter-terrorism policing requires that police combine their traditional role with a whole new set of skills, relationships, operations, and accountability. Yet, too many Commonwealth jurisdictions are content to thoughtlessly pass new laws or provide themselves and their police, paramilitaries and armed forces with broadened powers coupled with diminished accountability. The majority of responses in the Commonwealth have centred around increasing policing powers and reducing traditional human rights safeguards without addressing seminal issues of under performing and abusive policing which already plague a majority of nations in the association. Police reform remains a distant goal even as the most effective deterrent against those who oppose the state and its people is a reformed police that has the confidence of the population at large.

CHRI's present report which complements its 2005 report "Police Accountability: Too Important to Neglect, Too Urgent to Delay" examines anti-terrorism laws that relate specifically to police powers, and how they have effected policing on the ground. From the international framework that stipulates human rights and the rule of law as the central principles upon which counter-terrorism must be based, to the national laws that have re-shaped and re-directed policing efforts in this direction, CHRI examines how police powers have been enhanced without the necessary checks and balances that ensure police act appropriately in the interests of the security of people as well as the state.

CHRI illustrates some concerning abuses that have been committed under anti-terrorism laws. Much more than a litany of abuses, however, this report shows how many of these problems are the combined result of bad law and bad policing, as legislation creates unclear definitions and overly broad application. CHRI provides practical suggestions for how the state, police and communities can work together to improve the security for all in the effort to counter terrorism, and calls on the Commonwealth to provide leadership in this most important area.

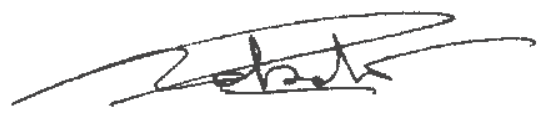

Sam Okudzeto

Chair, CHRI International Advisory Commission 


\section{ACKNOWLEDGMENTS}

"Stamping Out Rights", the 2007 report of CHRI's Advisory Commission to the Commonwealth Heads of Government was produced and made possible thanks to the help and support of so many people. Although it is impossible to refer to them all, we would like to acknowledge some that deserve particular mention.

Special appreciation goes to our indefatigable and determined coordinator Tessa Boyd-Caine who managed the team, guided the research, reviewed and refined the writing, oversaw publication and identified sources and networks throughout the process.

Credit goes to all our busy colleagues at CHRI who made time to answer our queries and read drafts. Peta Fitzgibbon, Venkatesh Nayak and Daniel Woods read a full draft and gave extremely useful advice, and Daniel and Caroline Avanzo kept the report together in its initial stages. Cecelia Burgman, Claire Cronin, Navaz Kotwal, Sumit Kumar, Reshmi Mitra, Madhumita Mitri and Shobha Sharma all read and commented on chapter drafts and Swati Mehta reviewed South Asia country reports and contributed useful insights. Aditi Datta went to great lengths seeking information from all her contacts; and Swayam Mohanty, Chenthil Paramasivam, Ranjan Kumar Singh and CHRI's administrative staff provided ongoing support and assistance. Research assistance was enthusiastically provided by CHOGM Report interns Lucy Adams, Sanmati Verma, and Meredith Wain.

The detailed comments and recommendations of external reviewers Alex Conte, Clare Doube, Alison Duxbury and Mandeep Tiwana were invaluable and the report improved significantly as a result of their feedback.

Many thanks to colleagues who reviewed our country reports and other analysis, often providing additional information and contacts: David Bamford, John Buttle, Tess Newton Cain, Ashley Carver, Colm O'Cinneide, Sinclair Dinnen, Alison Duxbury, Conor Gearty, Annette Hübschle, Martin Innes, Ahilan Kardigarmar, Jude Laing, Jude McCulloch, Cathleen Powell, Kent Roach, David Small, Elrena van der Spuy, Piccolo Willoughby and Katie Woods.

Thanks also to colleagues who provided country-specific and regional information and access to their own networks: Jo Ford and Arvinder Sambei of the Commonwealth Secretariat; Nick Hardwick and John Wadham of the Independent Police Complains Commission (UK); Sayeed Ahmad, Peter Anderson, Kemi Asiwaju, Ken Averre, Marcel Bent, Richard Bourne, Murray Burt, Victor Bwire, Mariya-Ahmed Didi, Sinclair Dinnen, Helen Donovan, Margaret Fenech, Alois Francis, Peter Grabosky, Anthony George Hill, Redson Kapindu, Edith Kibalama, Magnus Killander, Roosevelt King, Jude Laing, Priscilla Nyokabi, Padmaja Padman, Kathelo Pefole, Ejaz Elahi Piracha, Maureen Poole, John Pratt, Kaajal Ramjathan-Keogh, Charmaine Rodrigues, Simphiwe Shabangu, Anne Sitali, Brenda Smith, Philip Stenning, Carole Viljoen, Velma Wano, Richard Wildash and Piccolo Willoughby.

Most of all I would like to thank the CHOGM Report team, Tessa Boyd-Caine, Arnaud Chaltin, Gudrun Dewey, Manjiri Dube, Sophie Earnshaw, and Devika Prasad, who slaved through a hot and uncomfortable summer to produce this report. As always the report is the outcome of their cooperative efforts in research and writing for the main report as well as the supplementary country reports published separately online at www.humanrightsinitiative.org.

CHRI is deeply appreciative of the ongoing support of its institutional donors Ford Foundation and Sir Dorabji Tata Trust. CHRI sincerely acknowledges the help and support of all throughout the writing of this report, and assumes full responsibility for the opinions expressed here.

Maja Daruwala

Director, CHRI 


\section{Contents}

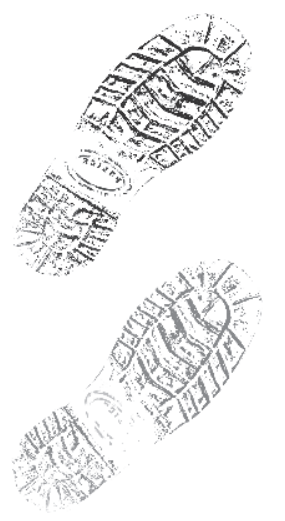

Chapter 1

Security at What Price?

i. “Terrorism”: Widely Spoken of, Poorly Understood..................................... 2

ii. The Changing Face of Policing ................................................................... 4

iii. The Prohibition on Torture: Collateral Damage in Counter-Terrorism........... 6

iv. True Security is Human Rights Protection...................................................... 9

\section{Chapter 2}

Human Rights: The International Security Framework.............................................. 11

i. Defining Terrorism in International Law.................................................. 12

ii. Regional Counter-Terrorism Policing Cooperation......................................... 14

iii. The Overarching Human Rights Framework................................................. 15

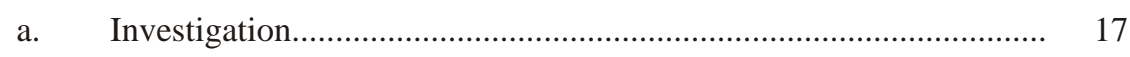

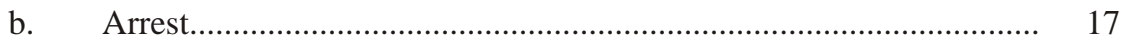

c. Detention..................................................................................... 17

d. The use of force and firearms and the obligation ............................... 17 to protect the right to life

e. Obligations to ensure police accountability........................................... 18

f. Obligations to train counter-terrorism police....................................... 18

\section{Chapter 3}

Trends in National Legislative Responses to Terrorism............................................. 19

i. Trends in National Legislative Responses to Terrorism.................................. 20

ii. The Shaping of Legislative Responses........................................................... 21

iii. The Process of Legislating.............................................................................. 23

iv. Unfettered Discretion: a Problem of Definition............................................. 24

\section{Chapter 4}

On the Ground: Police Powers in Practice.

i. Big Brother Policing: Surveillance, Stop and Search, and Profiling............... 30

a. Surveillance................................................................................... $\quad 30$

b. Stop and Search........................................................................... $\quad 30$

c. Terrorist Profiling............................................................................. 31

ii. Unwarranted Arrest................................................................................... 32

iii. Serving Time: Human Rights Behind Bars.................................................... 33

a. Preventive detention...................................................................... 33

b. Investigative detention.................................................................. 34

iv. Exceeding the Limit: the Unreasonable Use of Force.................................... 35

v. Strange Encounters of the Policing Kind................................................... 36

vi. Ensuring Counter-Terrorism is not Counter-Productive.............................. 37 


\section{Chapter 5}

Policing Terrorism: Is Accountability Getting Lost in the Fray?.................................. 39

i. Accountability: Non-Negotiable in Any Circumstance.................................... 40

ii. The Worst-Case Scenario: Absent Accountability, Flourishing Abuses.......... 41

iii. From Accountability to Impunity................................................................. 42

iv. Active Accountability: Setting a Good Example............................................. 42

v. The Challenges of Making Oversight Effective............................................. 44

vi. Accountability from Other Quarters............................................................. 45

vii. What Accountability is Needed?.................................................................. 47

\section{Chapter 6}

Concluding Recommendations.

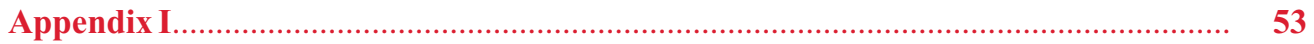

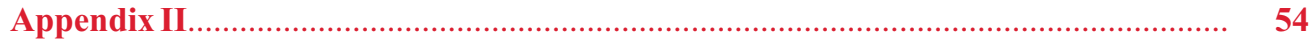

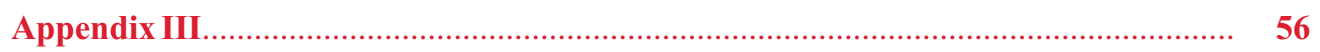

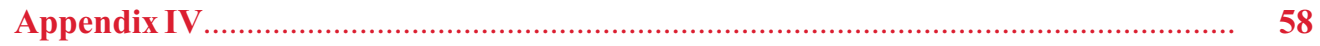

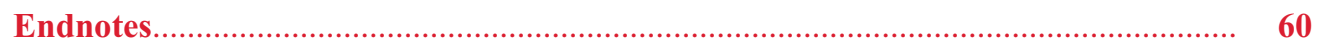

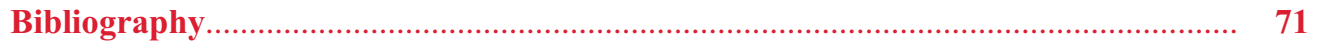

CHRI's Previous Reports to CHOGM................................................................. 82

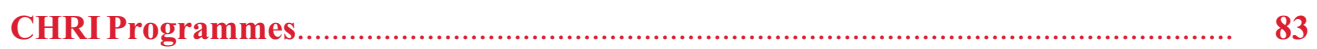




\section{CHRI 200\% REPORT}

S.josping Out Rights

Theimpact of anti-terrorism laws on policing

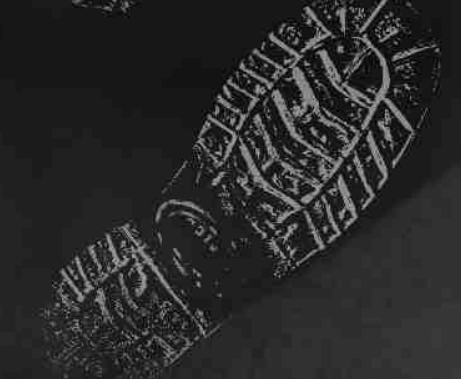




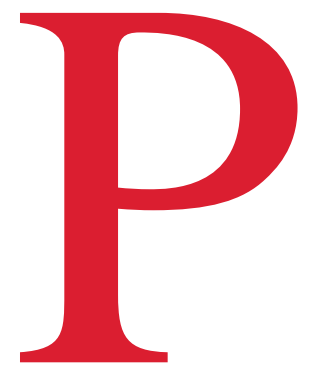

eople across the Commonwealth have the right to live free from fear and states have the responsibility to guarantee their safety and security. As with any other violence, states must effectively prevent terrorism. This is the role of counter-terrorism, and police are amongst the frontline agents in this response.

Even more than terrorism itself, the fear of terrorism is a growing global phenomenon and is often the driver for harsh state reactions that have little justification or legal validity. Tragically, in parts of the Commonwealth, measures to counter terrorism are also creating violence and insecurity. Most disturbingly they are undermining human rights, due process and the rule of law: national and international safeguards established to protect people against the abuse of state power.

\section{Right to Freedom from Fear}

The preamble of the Universal Declaration of Human Rights declares that freedom from fear is the "highest aspiration of the common people." The preambles of the International Covenant on Civil and Political Rights and the International Covenant on Economic, Social and Cultural Rights refer to "the ideal of free human beings enjoying freedom from fear."
In many places police powers have increased and discretion has been extended, whilst the protections of due process and accountability have fallen by the wayside. In the name of countering terrorism, arbitrary arrest and detention, enforced disappearances, torture and extra-judicial killings are too frequently employed with few consequences on the police. Joint operations between police and intelligence, military and paramilitary forces have blurred traditionally distinct roles and standards. Responsibility is declining through poor transparency and weak or absent checks and balances. Where counter-terrorism policing should be ensuring security of person and state, it often undermines the very institutions it is designed to serve, further spreading public fear and in some countries directly threatening the life and liberty of people it is supposed to protect.

\section{"Terrorism": Widely Spoken of, Poorly Understood}

The root causes of many acts of terrorism lie in people's disadvantage, and include poverty and severe and systematic social exclusion. These need to be urgently addressed. But disaffection does not license people to take the law into their own hands or commit terrorism. No means or cause, no matter how legitimate it might be, ever justifies

"Terrorists are terrorists. They have no particular religion or community. Labels are best avoided because if you do that you create a new set of
grievances." Manmohan Singh, Prime Minister of India terrorism. Equally, applying labels to something that is greatly feared but poorly understood does not help to address its underlying causes. The many histories of armed struggle in the Commonwealth including the 1950s Mau Mau resistance in colonial Kenya, the longstanding conflict between the Irish Republican Army and the British in Northern Ireland and the prolonged opposition to apartheid in South Africa have shaped the contemporary political situation in each country. These examples illustrate the intensely complex contexts in which terrorism can occur, and the challenges of meaning that come with its label. In the absence of a clear definition, the term "terrorist"

can be applied readily, and those it is applied to suffer severe consequences under counterterrorism laws. In particular the erosion of the presumption of innocence, and the weight and stigma attached to the terrorist label equate suspects with guilt in the eyes of police and the public. 
Terrorism is not a new phenomenon, but sustained international attention has heightened awareness of it. Anti-terrorism has an equally long and varied history. Nationally, most countries in the Commonwealth have at least some measures to deal with the threat or action of terrorism, and internationally, United Nations counter-terrorism conventions date from the 1960s. As terrorism globally shifts and evolves, bilateral, cross-border and regional instruments increasingly complement the framework of conventions established by the UN.

Yet despite thirteen international counter-terrorism conventions, numerous resolutions, and an attempt by the Security Council to define the term in 2004, the international community has still failed to agree on a legal definition of terrorism. This failure has allowed for the enactment of inconsistent national definitions across the Commonwealth, many of which provide broad catch alls applicable to numerous forms of lawful conduct. The wide scope of these laws has enabled police abuse in applying them to innocent individuals, groups and actions. Legal clarity is essential to define the boundaries of lawful police action and to ensure that extended powers granted by the law are not applied arbitrarily. Equally, legal frameworks ensuring police accountability are necessary to prevent police abuses of their powers.

Established principles of human rights and the rule of law are at risk from counter-terrorism measures that extend police powers and limit rights for suspects through enhancing the latitude given to police in the pre-trial stages of investigation, arrest, interrogation and detention. Beyond the limitations and derogations permitted in international law, there is nothing inherent to counter-terrorism that allows human rights to be undermined. Democratic policing is built upon respect for the rule of law and human rights standards. All policing, including counter-terrorism policing, must work according to these standards. Human rights are more than a set of ideals: they must determine both the way police do their job and the outcome of their actions. For example, the Police and Criminal Evidence Act (PACE) in the United Kingdom sets out safeguards to protect against the abuse of police powers to stop and search, arrest, detain, investigate, identify and interview detainees. ${ }^{3}$ Through PACE, human rights and the rule of law become the tools that provide the structure, process and objectives essential for ensuring security of people and the state. This code for general policing has been recently extended to cover counter-terrorism policing. ${ }^{4}$

The attacks in the USA on 11 September 2001 catapulted terrorism into the international eye by their visibility, severity and symbolism. The impact of this event was not just on public perceptions of terrorism; it also galvanised a powerful actor to drive the global community in new directions in responding to terrorism. The new response emphasised two major legal elements: control of the financing of terrorism through tighter international monetary mechanisms; and security by force, using police and the military as the means to achieve this.

Many Commonwealth states responded through enacting laws to track finances and money-laundering. But responses to terrorism, real or perceived, have also changed policing in the Commonwealth, as members took the opportunity to increase state and police power through amending existing laws and enacting special new legislation.

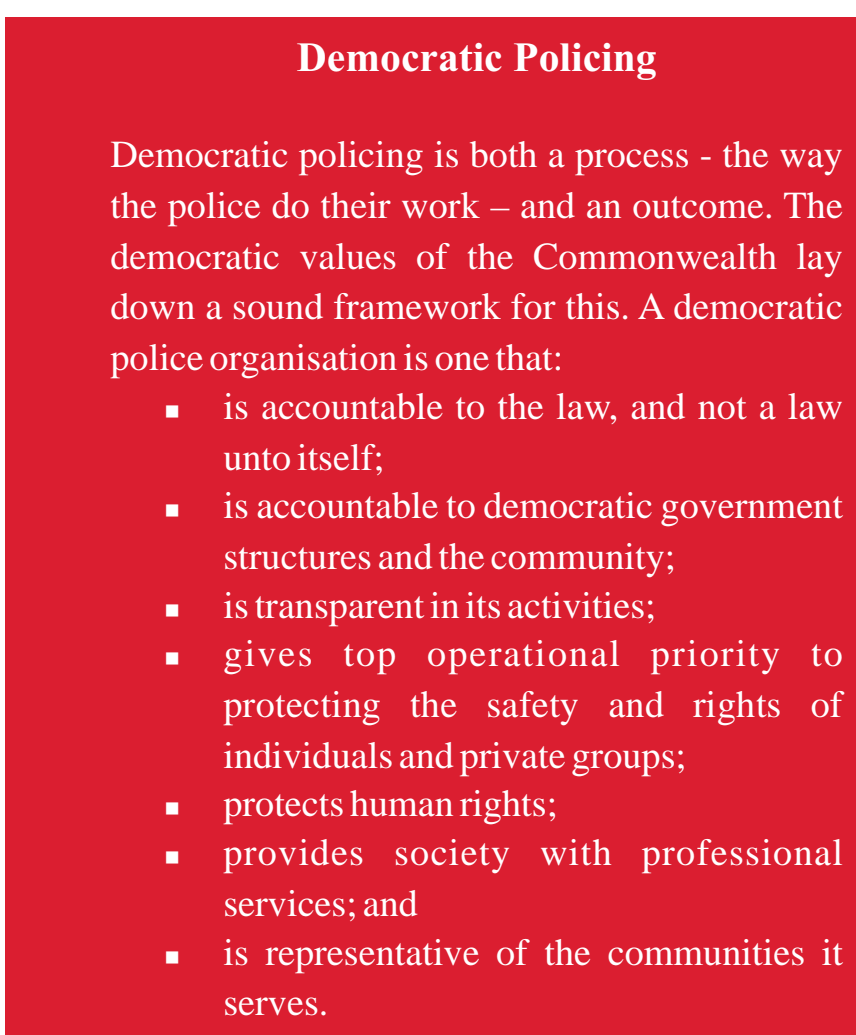




\section{The Rule of Law in the Commonwealth}

The rule of law is a protection against arbitrary governance. It is a fundamental principle requiring state authority to be used only in accordance with the law. The law must fulfil certain formal obligations: it must be written, adopted through democratic process, made public, and not be retroactive. It also implies the separation of powers through the independence of the judiciary, legal certainty, the equality of all before the law, the right of habeas corpus and the presumption of innocence. The content of law is limited as it must respect the provisions of the constitution as well as the state's obligations in international law, whether deriving from treaty or international principles, custom or practice governing the conduct of nations. Therefore implicitly the law must respect human rights. The rule of law is the basis of the Harare Commonwealth Declaration (1991) in which heads of government reaffirmed the core principles and values upheld by the Commonwealth.

\section{The Changing Face of Policing}

The key role of all policing is the preservation of law and order. Yet the emphasis on force in national security responses uses the threat of terrorism to justify excessive actions ranging from torture to arbitrary killing. Additionally police practices have become subject to less questioning and scrutiny. In this context human rights are often seen as oppositional to the objectives of security and as a barrier to counter-terrorism. Irrevocable universal concepts are being selectively discarded as privileges that cannot be afforded in the urgency to counter terrorism, when in fact they are the key to ensuring the safety of all. This changing face of policing increases the potential scope and severity of human rights abuses.

A considerable impact of anti-terrorism has been the merging of civilian police with military and paramilitary units, which has blurred the important boundaries between civilian policing and military function. It has encouraged violent and brutal techniques by police, and made a casualty out of human rights. This phenomenon is particularly evident in Commonwealth countries of South Asia. In the north-east of India the paramilitary Assam Rifles who have military officers serving in roles traditionally reserved for civilian policing have been implicated in numerous abuses including extrajudicial killings. ${ }^{6}$ In Pakistan both civilian police and the military share counter-terrorism responsibilities and powers under the executive authority of President Musharraf who was first brought to power via military coup in 1999, and the AntiTerrorism Act provides a procedure to call in the army to control and prevent terrorism. ${ }^{7}$

Militarised policing is not reserved solely for countering terrorism, as is evidenced by Bangladesh's Rapid Action Batallion (RAB). Formed in 2004 to deal with a break down of law and order, the RAB is often utilised to suppress opposition and political dissent through the use of arbitrary and excessive force, and there have been many reports of extra-judicial killings and torture by its members. However the subsequent extension of its mandate to include terrorism has licensed even further abusive practices. In the first week of the state of emergency in Bangladesh (January 2007), 19 people were reported killed by the RAB either in crossfire or detention. ${ }^{8}$ The RAB's ability to act with impunity derives from the poor degree of public transparency over its chain of command and the conflation of its policing and military elements which prevents oversight by existing police accountability mechanisms.

The militarisation trend of policing has been felt in African countries too. The anti-terrorism unit of the Ugandan government, a squad infamously labeled the Black Mambas, is a heavily armed joint military and police force. They quickly gained a reputation for violent, illegitimate arrests and raids under Presidential orders. ${ }^{10}$ Not only do they operate with extensive powers and an ambiguous chain of command, their accountability is severely undermined by actions such as alternating between military and policing uniform to reduce their detectability. This is a return to old practices in the region where military and police law enforcement was conflated, including in Botswana, Cameroon and Kenya.

CHRI 2007 REPORT: STAMPING OUT RIGHTS 
This shift has produced a situation where the state appears at war with human rights, where its own people are victims of both state practices and terrorism. Persistent conflict situations have reduced the distinction between peacetime policing and wartime militaristic interventions against the enemy. In Sri Lanka and the north-eastern states of India, armed forces mobilised to respond to insurgents have over time extended their dominion into operations usually reserved for civil police, such as the maintenance of law and order, day to day criminal investigations, arrest and prosecution. ${ }^{11}$

In northern Uganda armed conflict between the banned Lords Resistance Army (LRA) and the Museveni Government has been raging for over 21 years. Rather than strengthen law and order, the presence of Ugandan Government armed forces in the region has decimated the authority and capabilities of the civilian police. Even outside conflict zones, the military in the region have extended their control over land and population; and training, equipment and infrastructure have been diverted to the armed forces at the expense of police resources. Additionally, the failure to clearly demarcate law enforcement responsibilities in the region has resulted in absent lines of accountability.

Another disturbing development in the conflation of police and other forces is the direct involvement of foreign agents in national counter-terrorism measures. In Pakistan, there are growing concerns over reports of financial incentives for the capture of terrorism suspects by local police. This "cash for captives" arrangement leads to the arbitrary arrest and detention of people for whom there is no evidential basis to render them suspect. ${ }^{12}$ Authorities in Pakistan have openly stated that over 700 terrorism suspects have been arrested and passed to the USA. ${ }^{13}$ Once handed over, the whereabouts of the suspect often becomes a mystery. Moreover foreign agents are suspected of having known about or been present at interrogations where torture has occurred and have themselves been accused of inhumane treatment and practicing torture. $^{14}$

Police powers have also been granted to a wide range of security, intelligence and border control agencies. This distribution of power already existed in many South East Asian countries. For example, Brunei Darussalam law defines "police officer" to include

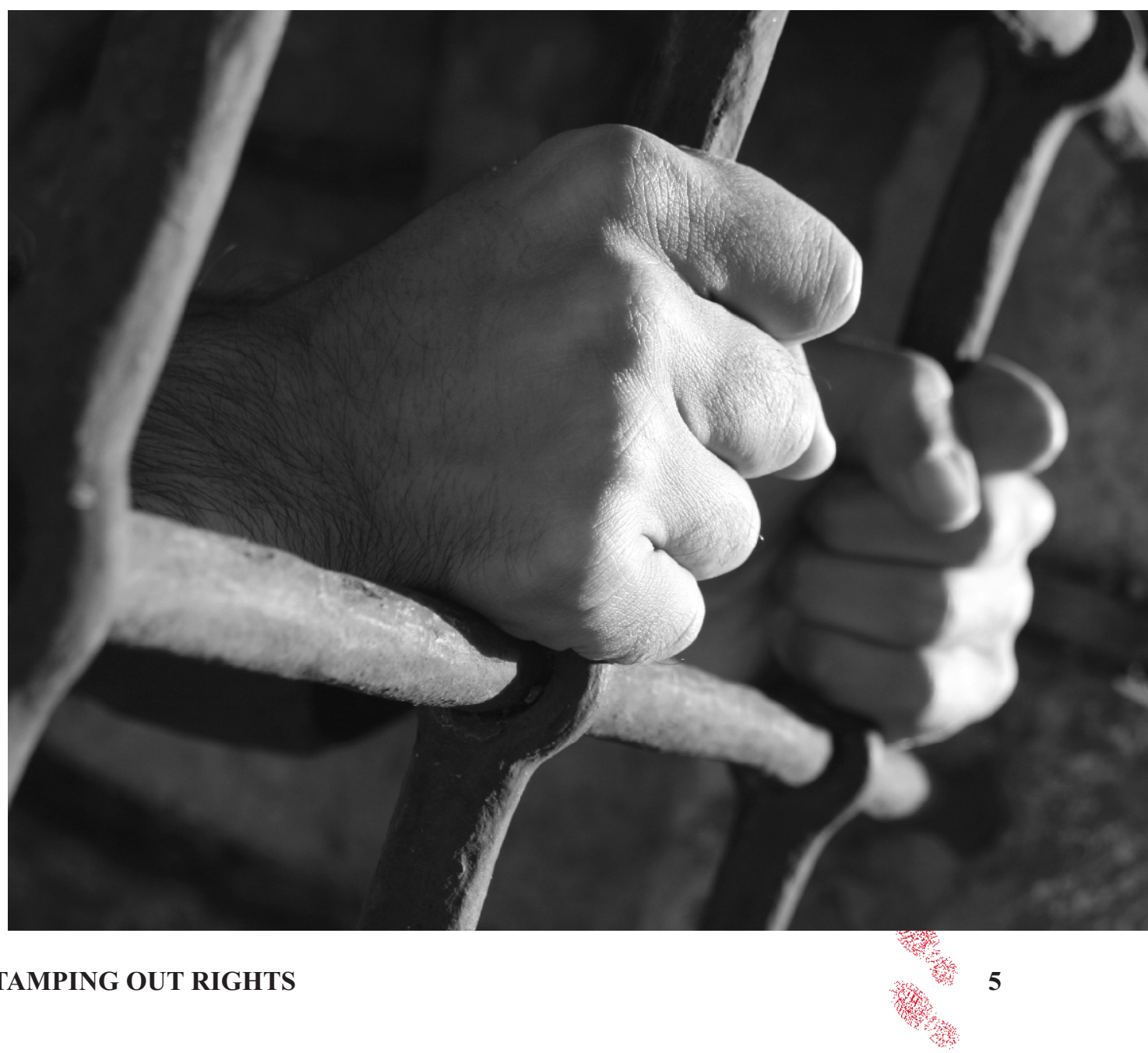


any member of any other security force in addition to the police, including prison officers, guards or watchmen if authorised by the Commissioner of Police. ${ }^{15}$ Some powers can even be extended to "any other individual" so authorised by a district police commander, introducing the potential for vigilantism through formal police powers. ${ }^{16}$ Australia's long-standing security legislation has been amended in the context of terrorism, extending the existing powers of the Australian Security Intelligence Organisation (ASIO) and police officers to forcibly remove, interrogate and strip search suspected terrorists and enabling incommunicado detention. ${ }^{17}$

The impact of the international climate is felt even when counter-terrorism measures rest only with civilian police. Specially trained police units who focus on counter-terrorism are creating problems for external accountability and are rupturing the internal coherence and stability of police organisations. Already under-resourced police forces are suffering from internal disputes over the perception that extra resources and specialist training are being diverted to counter-terrorism units with poor transparency regarding to whom they are answerable and what their role is.

\section{Where legal frameworks and police in the Commonwealth should be reforming to meet the principles of democratic policing, the true face of policing reflects increased powers, enhanced discretion, reduced access to justice and declining accountability in the prevailing atmosphere of anti- terrorism.}

Key indicators of undemocratic policing such as cultures of authoritarianism, and unaccountable and alienated police personnel, are widespread throughout the Commonwealth. In some countries police are functioning as an essential service while in others they function as a force to be reckoned with; a law unto themselves. Yet there are examples where communities have the will, and police welcome the opportunity, to work together strengthening relationships in the effort to counter terrorism. In the UK, Muslim community organisations have called for a united front against terrorism and appealed to all Muslims to work hand in hand with the police. ${ }^{18}$ Far from idealistic notions, these approaches demonstrate the importance of public engagement in the success of counter-terrorism operations.

\begin{abstract}
The responsibility for this environment does not rest upon the shoulders of the police alone. Lawmakers are responsible for the enactment of provisions allowing the creation of mixed forces and the increased militarisation of the police practices. Operational challenges for the police such as gaining intelligence and the ability to act upon it are magnified in such a climate. Lawmakers should provide legal clarity on the intent, scope and application of legislation that is essential to ensure police are accountable in all conduct. Where legal frameworks and police in the Commonwealth should be reforming to meet the principles of democratic policing, the true face of policing reflects increased powers, the abuse of enhanced discretion, reduced access to justice and declining accountability in the prevailing atmosphere of anti-terrorism.
\end{abstract}

\section{The Prohibition on Torture: Collateral Damage in Counter-Terrorism}

Nowhere is the erosion of human rights more visible than in the dilution of the prohibition on torture. Torture is universally prohibited under all circumstances, and no person may be subjected to cruel, inhuman or degrading treatment or punishment. ${ }^{19}$ Until recently torture was condemned 
as a gross violation of human rights. Yet fear of terrorism, and the desire to respond or be seen to be responding to it, is steadily undermining this absolute prohibition.

The "war on terror" has permitted what was impermissible to become a subject of debate. The now infamous Gonzales Memo, written for the White House by then leading counsel Alberto R. Gonzales argued that captured Taliban members were not protected under the Geneva Convention as prisoners of war. ${ }^{20}$ The memo claimed that international law was too strict for detainees of the "war on terror".

In the United Kingdom the House of Lords overruled a decision of lower courts and reaffirmed that torture is a violation of international law and that no court should admit as evidence confessions obtained through its practice. Yet their Lordships also changed the burden of proof so that for evidence to be declared inadmissible it must be established that it was obtained through torture. $^{21}$ The dissenting view indicates the implications:

"This is a test which, in the real world, can never be satisfied. The foreign torturer does not boast of his trade. The security services ... do not wish to imperil their relations with regimes where torture is practiced. The special advocates have no means or resources to investigate. The detainee is in the dark. It is inconsistent with the most rudimentary notions of fairness to blindfold a man and then impose a standard which only the sighted could hope to meet. The result will be that, despite the universal abhorrence expressed for torture and its fruits, evidence procured by torture will be laid ... because its source will not have been 'established'.,22

In a direct blow to the principles of international law, this judgment ignores the responsibility of the UK to refuse to entertain evidence which has been obtained by torture. ${ }^{23}$

This interpretation appears to encourage the so-called outsourcing of torture: the practice of sending a suspect to another state less respectful of its prohibition, for the purpose of interrogation. A state, especially one with strongly developed oversight institutions and public opinion, that does not want to be seen as directly involved in practicing torture, tries to absolve itself of responsibility for that practice if it takes place outside its jurisdiction. Illustratively, the South African government has been criticised for justifying its return of a Pakistani national to his home country on the grounds that it could not be certain that the victim would be tortured there. $^{24}$

The failure to stay true to the inviolable prohibition against torture by major powers has allowed many others to justify the unjustifiable. For example in India a senior police officer openly declared that an accused brought on television to publicly attest to his involvement in a failed attack on Parliament had been tortured and that "torture was the only deterrent to terrorism." 25 This bold assertion produced little public condemnation, nor action from courts or human rights

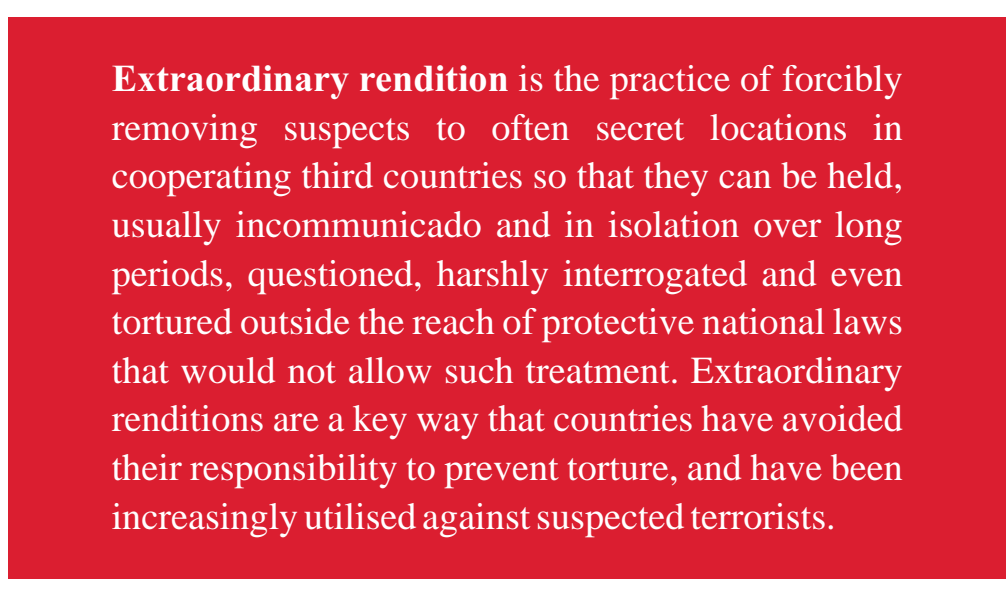
institutions. Elsewhere, concern not to appear "soft" on terrorism has tempered responses to torture. In Australia, despite strong allegations of abuse, it took five years of constant lobbying by family and civil society, and public outcry, before the government was persuaded to seek the discharge into their own custody of Australian terrorism suspect David Hicks from the Guantanamo Bay detention centre, against which allegations of torture, inhuman and degrading treatment had been repeatedly made. 
In many countries existing norms and practices now reinforced by new anti-terrorism laws also create environments that encourage the use of torture, which is already common and indeed endemic within many of the Commonwealth's unreformed police forces where cultures of impunity prevail. Many laws grant the police de facto immunity from prosecution especially when involved in so-called anti-terrorism activities, particularly in South Asia and Africa. ${ }^{26}$ Extendable periods of

\section{“Jihad Jack"}

Australian Jack Thomas, otherwise known as Jihad Jack, stepped into the international limelight in 2006 when he was convicted of receiving funds from

Al Qaeda and carrying a false passport. His conviction was substantially based on a confession obtained by the Australian Federal Police in Pakistan the year before. The Court of Appeal quashed the conviction because it could not be shown to have been made without coercion. ${ }^{28}$ preventive and investigative detention and the admissibility of confessions also increase the risk of torture. Even seemingly beneficial provisions for quick investigation and trial can operate to reduce the rights of suspects. Illustratively, Pakistan's special tribunal laws set strict time limits of no more than seven days each for investigation and prosecution. This leaves very little time for thorough investigation. Since confessions can form the basis of conviction (providing there is other evidence that suggests reasonable probability that the accused committed the offence), the pressure to secure evidence for the conviction might push the investigators to obtain quick confessions. This increases the likelihood of resorting to unlawful means, while the haste of the trial period reduces the protections of due process. ${ }^{27}$

The Commonwealth's position on the issue of torture is clear - at least on paper. The Secretary General has condemned its use as "a violation of human rights, a violation of international law and a violation of everything for which the Commonwealth stands." ${ }^{29}$ Yet 24 out of 53 member states are not party to the Convention Against Torture (CAT), including almost all of the Caribbean and Pacific Island states. ${ }^{30}$ The Optional Protocol provides for an independent, international body to visit and investigate places of detention in the ratifying country. So far only the Maldives, Malta, Mauritius, New Zealand and the UK have ratified the Optional Protocol, while Cyprus, Ghana, Sierra Leone and South Africa have signed but not yet ratified. Even as the Commonwealth continues to encourage states to ratify core human rights treaties, the failure to endorse such a key instrument as the CAT has not attracted any particular condemnation from the Commonwealth Ministerial Action Group, whose mandate includes responding to serious or persistent violations of the Commonwealth's fundamental values as enshrined in the Harare Declaration.

\section{The UN Human Rights Committee} emphasises that, in spite of the difficulties governments may face in fighting terrorism, "no exceptional circumstances whatsoever can be invoked as a justification for torture.",32
The fact remains that torture is illegal. Police cannot set aside its prohibition when it is convenient to do so. The UN Human Rights Committee emphasises that, "no exceptional circumstances whatsoever can be invoked as a justification for torture."

Not only is torture illegal, it is plainly counterproductive. Victims in pain will do anything to put a stop to their torment and information obtained under torture is unreliable. Innocent people are extremely likely to confess to crimes they did not commit or validate information they do not know. Furthermore, practices of torture by police alienate whole communities and breed contempt for the law, creating fear and hatred of law enforcers and 
diminishing their legitimacy. As the experience of policing in Northern Ireland shows, torture in the interrogation of terrorist suspects only "galvanised the nationalist community in opposition to British rule and there was an immediate upsurge in violence against the security forces." ${ }^{, 33}$

Through its own lawlessness the practice of torture supports the very objectives of terrorists. It distances its victims from the objectives of the state, reduces any possibility of garnering intelligence from a cooperative public and defeats the hard work police put in to win their support.

\section{Police practices that violate human rights are not just breaches of international law, they are ineffective, counter-productive methods of policing.}

Any understanding of national security must be guided by the need to protect the physical boundaries, symbols and infrastructure of the state and the ideal of democracy. Democracy requires that national security cannot be achieved unless each and every person in the country feels safe. In other words, national security requires human security. Laws and actions that provide safeguards are necessary for the safety of the state and its people, where they protect life and property as well as liberty and rights.

To be effective the powers provided to police to counter terrorism must be appropriate, proportionate and humane, complying with the standards set out in international law. If not, they undermine the democratic legitimacy of the state. Overzealous powers reduce the legitimacy of the police as representatives of the state; diminish the co-operation of the people in supporting police roles and functions; and encourage criticism of the police and the state.

With the perception of increasing danger from terrorism, extraordinary powers have become a benchmark for everyday

\section{True Security is Human Rights} Protection

I do not believe there is or there can be a trade-off between the effective fight against terrorism and protection of civil liberties. If, as individuals we are asked to give up our freedom, our liberties and human rights, for protection against terrorism, and we do it, do we in the end have protection? I think we need to be careful not to undermine human rights and civil liberties in this fight against terrorism because if we do, we are handing the terrorists a victory they cannot win on their own. ${ }^{34}$

Kofi Annan, UN Secretary General (1996-2006) security. In their shadow, inalienable rights are being negligently cast aside. These include the right to life; the right to freedom from torture; the right to freedom from discrimination; the right to freedom from arbitrary arrest and detention; the right to a fair trial; the right to freedom of expression; the right to freedom of association; and the principle of legal certainty. Justified as necessary to counter terrorism, the violations of these rights and principles are significantly reducing security. The intended end of preventing terrorism is frequently used to justify the means of torturing suspects to obtain information. The fact that this is both a direct violation of a fundamental obligation to uphold human rights, and Violating human rights cannot simultaneously protect human rights. produces unreliable information, does not deter police from such practices. Nor does it produce public outcry in an environment increasingly desensitised to human rights violations through fear of the insecurity created by terrorism. Media representations of popular opinion reflect the extent 
of this fear, but fail to show that this climate is influenced by state actions as well as terrorism, particularly when policing targets communities who are continuously identified with terrorism in the context of declining safeguards to protect them.

Harsh policing coupled with harsh laws only increases the motivation for terrorism. Police responses to terrorism have to be just and fair, not just because of international obligation but because that is a fundamental distinction between legitimate state action and terrorism. The evidence of successful democracy, and thereby making societies more secure, is the only effective response to the anti-democratic arguments of terrorist leaders. True security is human rights protection. 


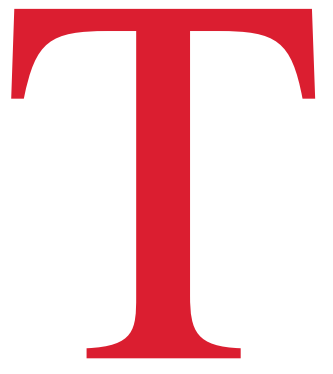

he international dimensions of terrorism have prompted increased attention from the global community to cooperate in its prevention worldwide. Although the first United Nations (UN) counter-terrorism convention dates back to 1963, it was only in 2001 that the UN Security Council ordered states to take specific action by implementing laws to address the threat of terrorism. Within days of the attacks in America, the Security Council called on states to "work together urgently to bring to justice the perpetrators, organisers and sponsors" of the attacks and for the international community to "redouble their efforts to prevent and suppress terrorist acts" by cooperating with and implementing all existing anti-terrorism conventions and resolutions. ${ }^{2}$ This was closely followed by the unprecedented Resolution 1373 which demanded states achieve these aims within months and

"We need to get the message through to every single individual in every single Commonwealth member country that to violate human rights is to violate the core values of the Commonwealth. Human rights are a way of life, not a privilege"

Commonwealth Secretary General Don McKinnon (2005) ${ }^{l}$ established the UN Counter Terrorism Committee to monitor the national implementation of counter-terrorism measures. ${ }^{3}$ However, while all resolutions carry the implicit requirement that they be followed in a manner consistent with states' human rights obligations, 1373 failed to explicitly state this. As a result, in the name of security, many Commonwealth members enacted legislation allowing for police responses in violation of paramount obligations to uphold entrenched human rights and freedoms.

The failure to assert these requirements expressly in Resolution 1373 proved a catastrophic mistake because it seemed to indicate that anti-terrorist measures especially as they relate to policing fall outside the internationally recognised framework of human rights. It was two years too late when the Security Council directly urged states to "ensure that any measure taken to combat terrorism comply with all their obligations under international law [and] in particular [with] international human rights, refugee and humanitarian law." ${ }^{4}$ But by 2003 many Commonwealth governments had already used 1373 to justify the revival of outdated draconian security laws and enact new, repressive antiterrorism legislation undermining the rule of law and

The international position is clear that the highest standards of democratic policing must continue to apply in the implementation of all anti-terrorism measures. allowing for police practices in direct violation of human rights standards. By 2006, the UN released a Global Counter-Terrorism Strategy deploring the occurrence of human rights violations in the fight against terrorism, asserting that all measures must respect human rights, uphold certain rights as nonderogable in any circumstance and ensure lawful derogations are of an exceptional and temporary nature. ${ }^{5}$ The international position now makes clear that the highest standards of democratic policing must continue to apply in the implementation of all anti-terrorism measures.

\section{Defining Terrorism in International Law}

It is universally accepted that for actions to attract criminal sanction they must be clearly defined. However, despite widespread use of the terms terrorism, terrorist and terrorist act, the international community has found itself unable to agree upon a definition. In 2000, a UN Ad Hoc Committee began developing a Comprehensive Terrorism Convention aimed at incorporating the existing conventions on terrorism and establishing a single unified definition. ${ }^{6}$ While the drafting is almost complete there remains disagreement over how a definition should address state actors and national liberation and self-determination movements. 
Until a consensus is reached, Security Council Resolution 1566 (2004) provides a working definition of what constitutes a terrorist act. The conduct must be contained within existing anti-terrorism conventions; committed with the intention of causing death or serious bodily injury or the taking of hostages; and with the purpose of provoking a state of terror, intimidating a population, or compelling a government or an international organisation to do any act. There is no requirement for motive so it is irrelevant whether the act has a religious, ideological or racial motivation.

Significantly, Resolution 1566 limits the proscription of terrorism to the offences set out in the 13 international counterterrorism conventions. Three of these aim to prevent certain terrorist acts.

- The Nuclear Material Convention (1980) prohibits any entity from internationally transporting or storing nuclear material.

- The Plastic Explosives Convention (1991) requires states to prohibit and prevent the production of unmarked explosives, thereby limiting their availability to terrorists.

- The Terrorist Financing Convention (1999) criminalises the funding of terrorism.

The remaining ten classify specific acts as punishable terrorism offences and include four conventions that were developed after a spate of highjackings in the 1960s.

- The Aircraft Convention (1963) requires the state of registration to have legal jurisdiction over any offences committed on the aircraft.

- The Unlawful Seizure Convention (1970) makes it a severely punishable offence to unlawfully intimidate, exercise control over or seize a civilian aircraft by force or threat.

- The Civil Aviation Convention (1971) and the Airport Protocol (1988) cover a series of other offences including acts of violence or damage to an aircraft or any property at an international airport.

- The Diplomatic Agents Convention (1973) covers the murder, kidnapping, deprivation of liberty or any other attacks on heads or representatives of state, their families and international organisations.

- The Hostages Convention (1979) covers the taking of hostages to compel a state, organisation or person to do something conditional on the release of the hostage.

- The Maritime Convention (1988) covers the use of force or intimidation to seize, control or destroy a ship or its cargo.

- The Maritime Protocol (1988) applies to the same acts on fixed platforms on the continental shelf.

- The Terrorist Bombing Convention (1997) covers the use of explosives and other lethal weapons, "particularly where they are intended to provoke a state of terror" (their use by state forces in an armed conflict situation is excluded from the Convention).

- The Nuclear Terrorism Convention (2005) covers the unlawful and intentional possession or making of radioactive material and devices with the intent to cause death, serious bodily harm, or substantial damage to property or the environment. 
Human Rights: The International Security Framework

\section{Regional Counter-Terrorism Policing Cooperation}

The international dimensions of terrorism have led to cooperating police organisations and networks developing in various regions of the Commonwealth. They focus on intelligence and information sharing, training to prevent and respond to cross regional attacks and forming agreements for the extradition

\section{A Working Definition of Terrorism}

"Criminal acts, including against civilians, committed with the intent to cause death or serious bodily injury, or taking of hostages, with the purpose to provoke a state of terror in the general public or in a group of persons or particular persons, intimidate a population or compel a government or an international organisation to do or abstain from doing any act, which constitute offences within the scope of and as defined in the international conventions and protocols relating to terrorist, are under no circumstances justifiable by considerations of a political, philosophical, racial, ethnic, religious or other similar nature."

UN Security Council Resolution 1566 (2004) and prosecution of terrorists. For example, the Council of Europe Convention on the Prevention of Counter Terrorism (2006), the African Union's Convention on the Prevention and Combating of Terrorism (1999) and the Inter-American Convention Against Terrorism (2002) all provide definitions of terrorism and seek to boost state cooperation to counter it within their regions. ${ }^{7}$ Unfortunately, the African convention makes no reference of an obligation for states to respect human rights in counter-terrorism efforts. More positively, Article 15 of the American convention positions human rights as central to counter-terrorism, stipulating that respect for the rule of law and human rights are primary considerations. The Council of Europe convention takes the additional step of explicitly directing parties to ensure that police training measures to prevent terrorism fully respect the ICCPR and other human rights obligations. ${ }^{8}$ While the African convention gives a farreaching definition of terrorism, the European and American instruments limit the definition of terrorist offences to those outlined in the UN Counter-Terrorism Conventions. ${ }^{9}$

Global law enforcement organisations that have existed for many years are also cooperating more closely today in light of the perceived increased threat from terrorism. For example, all Commonwealth states, excluding the Pacific Island countries, are members of Interpol, which was formed in 1923 to develop cross border police cooperation. ${ }^{10}$ The traditional role of Interpol is as a resource for policing expertise and best practice standards. However, with the growth of international terrorism, it now has broad functions of investigation. After the 2001 terrorist attacks in the USA, Interpol created four regional taskforces to investigate terrorist groups in Southeast Asia, Central Asia, South America, and Africa. ${ }^{11}$ While the taskforces have not deployed ground officers, they have formed strategies on trans-border terrorism and organised regional training activities to harmonise police procedures across states. Similarly, the South African Regional Police Chiefs Cooperation Organisation - including police chiefs from Botswana, Malawi, Mauritius, Mozambique, Namibia, South Africa Swaziland, Tanzania and Zambia - now has a counter-terrorism task force that coordinates law enforcement and cross border agreements throughout the region and works closely with Interpol. ${ }^{12}$ Importantly, the Organisation's code of conduct highlights that police must uphold human rights in all their duties. ${ }^{13}$ In the Pacific region, a number of countries have been involved in developing the "Law Enforcement in Counter Terrorism" (LinCT) program, providing education on counterterrorism, intelligence and leadership for the Pacific region with input from senior police officers in Australia, Canada, New Zealand, the UK and the USA. ${ }^{14}$ Elsewhere, in 2005 the USA donated \$US500 million to a seven-year counter-terrorism program training military and police forces in West Africa. ${ }^{15}$ It is important that these initiatives for cooperation respect human rights and instil democratic policing principles in the counter-terrorism measures taken in these regions. 


\section{Human Rights Instruments Playing the Same Tune Throughout the Commonwealth}

The human rights obligations of Commonwealth countries derive from their membership of the UN and regional organisations.

The Universal Declaration of Human Rights (UDHR), the International Covenant on Civil and Political Rights (ICCPR) and the International Covenant on Economic, Social and Cultural Rights (ICESCR) together constitute the International Bill of Human Rights. They set out minimum entitlements and standards protecting individuals from abuses of power by state actors. The ICCPR protects rights such as those to life, self-determination, liberty, security, freedom from torture or cruel, inhuman and degrading treatment and freedom of thought, conscience, religion, opinion, expression, peaceful assembly and association. The ICESCR includes the rights to work, a reasonable standard of living, education and cultural life free from discrimination.

The ICCPR recognises that when it is absolutely essential to protect national security, public order or the rights and freedoms of others, the state may place limitations on certain rights, such as the right to freedom of expression, freedom of association, the right of peaceful assembly and the right to privacy. ${ }^{17}$ There are strict legal requirements for any derogation requiring that the limitation of rights is proportional and necessary for the emergency, the measures are applied without discrimination, and the member states inform the UN Secretary General of the state of emergency. Most importantly, all derogations of the ICCPR must be of "an exceptional and temporary nature". ${ }^{18}$ The UN Human Rights Committee emphasises that these safeguards are essential to maintain the "principles of legality and rule of law at times when they are most needed". ${ }^{19}$ Regardless of the gravity of the emergency, certain rights are non-derogable: the right to life, freedom from torture, freedom from enslavement or servitude, protection from imprisonment for debt, freedom from retroactive laws, the right to recognition as a person before the law, and the right to freedom of thought, conscience and religion. ${ }^{20}$ Additionally, the UN Human Rights Committee has asserted that the presumption of innocence and the right to have detention judicially reviewed can never be suspended. ${ }^{21}$

Binding human rights standards for counter-terrorism policing are also contained in additional instruments such as the Convention Against Torture, the Convention on the Elimination of all Forms of Racial Discrimination and the Convention Relating to the Status of Refugees. Ratification to these treaties obliges governments to implement them in national law.

Specific policing standards are also set out in the Code of Conduct for Law Enforcement Officials and the Basic Principles on the Use of Force and Firearms by Law Enforcement Officials, which are not binding but hold strong moral force and provide practical guidance. Yet many Commonwealth countries do not adhere to established principles of policing and others have marginalised them in efforts to combat terrorism.

The Commonwealth Secretary General has suggested that "it is possible to see a day where ratifying the two international covenants on political and socio-economic rights becomes the minimum standard" for Commonwealth membership. ${ }^{22}$ Of the $33 \mathrm{UN}$ member states that have not ratified the ICCPR, 18 are Commonwealth countries. Yet this failure of one third of the Commonwealth to commit to the ICCPR has so far triggered little reaction from the Commonwealth's watchdog bodies. 


\section{International Watchdog for Human Rights in Counter-Terrorism}

The tasks of the Special Rapporteur include investigating alleged human rights violations in counter-terrorism measures, recommending and promoting best practice measures, developing dialogue with a range of international actors, and reporting regularly to the UN Commission on Human Rights and the UN General Assembly. ${ }^{16}$ Although the Special Rapporteur has an ongoing and important role to play it is still unclear whether the mandate will be renewed after its scheduled end in 2008.

\section{The Overarching Human Rights Framework}

The expansion of international counter-terrorism law and cooperation has simultaneously reaffirmed the duty of states to develop police responses within the overarching framework of human rights. This is universally accepted and signalled by the creation in 2005 of the Special Rapporteur on the Promotion and Protection of Human Rights and Fundamental Freedoms While Countering Terrorism by the UN Commission on Human Rights. The obligation to ensure that counter-terrorism measures and policing adhere to internationally recognised human rights standards applies to Commonwealth countries by virtue of their membership of the association, of regional organisations and the international community.

Regional Human Rights Instruments Strengthening the International Framework

African Charter on Human and Peoples'Rights (Banjul Charter)

Applies to the Commonwealth countries of Botswana, Cameroon, the Gambia, Ghana, Kenya, Lesotho, Malawi, Mauritius, Mozambique, Namibia, Nigeria, Seychelles, Sierra Leone, South Africa, Swaziland, Tanzania, Uganda and Zambia. Seen as a landmark treaty in Africa, the Charter sets out civil, political, economic, social and cultural rights and freedoms and the safeguards essential for their protection. It established the African Commission on Human and Peoples' Rights, which requires states to submit a report every two years outlining national measures upholding the Charter. ${ }^{23}$

\section{American Convention on Human Rights}

Applies to the Commonwealth countries of Barbados, Canada, Dominica, Grenada and Jamaica. Its central provisions recognise the civil and political rights contained in the ICCPR. It also established the Inter-American Commission on Human Rights, which examines individual complaints; and the Inter-American Court of Human Rights, which can interpret and apply the Convention. None have signed or ratified the Inter-American Convention to Prohibit and Prevent Torture, which requires states to provide police training with an emphasis on the prohibition of torture in interrogation, detention and arrest. $^{24}$

European Convention on Human Rights and the European Code of Police Ethics

Applies to the Commonwealth countries of Cyprus, Malta and the UK and contains all the protections found in the International Bill of Rights. The European Court of Human Rights has jurisdiction to hear individual complaints on infringements of the Convention. While not holding the same force as a convention, the 2001 European Code of Police Ethics aims to increase respect for human rights in law enforcement and boost public confidence in the police service by requiring police to act in a fair manner, impartially and without discrimination. ${ }^{25}$ 
Under the rule of law, Commonwealth police must serve the public and are answerable to the executive. The UN Code of Conduct for Law Enforcement Officials requires police to represent and be responsive and accountable to the community as a whole. ${ }^{26}$ Their powers must be precisely defined by law, known to the public, be fair and just in themselves and applied to all people without discrimination. In the course of their duty police must "respect and protect human dignity" and "maintain and uphold the human rights of all persons" as set out in the International Bill of Human Rights. ${ }^{27}$ The UN Code of Conduct applies to any officer of the law who exercises police powers, including military or state security forces, especially if they are using powers of arrest or detention. ${ }^{28}$ These standards are clearly set out in a UN Human Rights manual on police training and are especially important in the context of counter-terrorism where procedural safeguards are weakened and many laws allow police to arrest terrorism suspects without a warrant, without charge and without disclosing the evidence against them. ${ }^{29}$

\section{Investigation}

The collection of evidence and investigation of terrorism must be conducted only according to law, with due cause and respect for human rights and should not be arbitrary or unduly intrusive. Police actions are arbitrary if they are discriminatory; conducted without legal basis; unreasonable; disproportionate in the circumstance; or without fair or substantial cause.

\section{Arrest}

No-one can be subject to arbitrary arrest and any person detained must be "promptly informed" of the charges against them. ${ }^{30}$ Police must record the reason for arrest, the time of arrest, the time transferred to a place of custody, the time of appearance before a judicial authority, the identity of officers involved, precise information on the place of custody and details of the interrogation. All information must be provided to the suspect and their legal counsel.

\section{Detention}

Anyone arrested has the right to trial within a reasonable time or to be released. Detention pending trial must always be the exception rather than the rule. The right to judicial review, also known as the right of habeas corpus, is the principal safeguard against arbitrary detention and absolutely non-derogable. ${ }^{31}$ It must be respected by all Commonwealth states as a "peremptory norm of international law." ${ }^{32}$

\section{The use of force and firearms and the obligation to protect the right to life}

The right to life is held to be "the supreme right" in international law and is enshrined in a number of international instruments that place a positive obligation on Commonwealth states to uphold it. ${ }^{33}$ States have a strict duty to "prevent arbitrary killing by their own security services." ${ }^{34}$ All police conduct must observe the "PLAN" principles of proportionality, legality, accountability and necessity. ${ }^{35}$ Force can only be used when it is "strictly necessary" and lethal force can only be used as a last resort. Any force must be exercised with restraint and proportionate to the objective considering the aim of the police operation, the danger of the situation and the degree to which the force might risk life. ${ }^{36}$ Lethal force is only lawful if the police can show that no other action could have achieved the same lawful purpose. ${ }^{37}$

Stemming from the state's obligation to protect the right to life, police have a duty to properly prepare and plan counter-terrorism operations so as to avoid any loss of life. A number of international courts have established case law setting out requirements for police. In 1996, the European Court of Human Rights considered the lethal shooting of four unarmed IRA terrorist suspects by the UK Special Air Squadron in Gibraltar. ${ }^{38}$ Although the counter-terrorism team believed lethal force was the only way to prevent the suspects from detonating a car bomb, the 
Court found that the suspects could have been arrested at an earlier stage and the killing prevented if the operation had been better planned. Proper preparation might have involved assigning an adequate number of officers to the incident and giving them supervision and directions as to how to control the situation without resorting to lethal force.

\section{Obligations to ensure police accountability}

Respect for the right to life also requires independent public investigation into any death where agents of the state may be implicated. ${ }^{39}$ Of particular relevance to counter-terrorism operations, the UN Basic Principles require a thorough, prompt and impartial investigation of cases of suspected extra-legal, arbitrary or summary execution. ${ }^{40}$ Most importantly, any investigation must be thorough and professional, with full resources and expertise, so as "to determine the cause, manner and time of death, the person responsible, and any pattern or practice which may have brought about that death." ${ }^{41}$

Obligations to train counter-terrorism police

Police must be trained in human rights, ethics, methods for the peaceful settlement of conflict situations and appropriate investigative procedure..$^{42}$ In line with this, the Commonwealth Law Ministers 2002 meeting mandated the Commonwealth Secretariat to develop human rights training programs for police officers, and the Human Rights Unit commenced a police-training program in $2004 .^{43}$ Starting in West Africa, it is now working with "police trainers from 25 Commonwealth countries in East, West and Southern African, the Indian Ocean, and the Pacific. ${ }^{\prime 4}$ It also published a manual on human rights education for police that points out the conventional wisdom that "the most effective counter-terrorism measures are not exceptional: they involve ordinary police investigation and community liaison. ${ }^{, 45}$ It highlights that the community can provide the police with the "best source of intelligence, information and support. ${ }^{, 46}$ This work is an important step by the Secretariat in combating the widespread abuses of power and poor accountability of police throughout the Commonwealth. But training must be continually reinforced to become embedded in police practice. Moreover, it is not enough to shift the basic elements of policing from poor performance and little accountability to an approach based on respect for human rights. To fulfill their international obligations, all countries must have clearly declared public policy on counter-terrorism, grounded in respect for the rule of law and informed by public consultation and debate. The institutions of the Commonwealth can ensure this through drafting effective, workable policy; sharing lessons of good practice; and providing technical assistance to ensure implementation.

In 2005 CHRI called for the Commonwealth Secretariat to establish an expert group on policing with a mandate to examine policing structures in member states and "to develop guidelines on training, accountability mechanisms, legal regimes and mutual professional support to ensure democratic policing. ${ }^{, 47}$ Acting on this recommendation is an essential step in addressing the flagrant violations of international law enforcement standards in the counter-terrorism context.

The 2005 Commonwealth Heads of Government Meeting recognised that all action to fight terrorism must be conducted in conformity with international human rights law. ${ }^{48}$ Despite these words, anti-terrorism laws have allowed human rights to fall victim to police malpractice. 
CHRI 2007 REPORT

Stamping Out Rights

The impact of anti.terrorism laws on pollicing

,

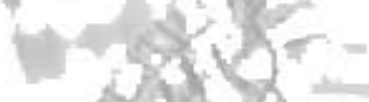

$\sin 2 \mathrm{x}$

$+x^{2}, 7,7 y^{2}$
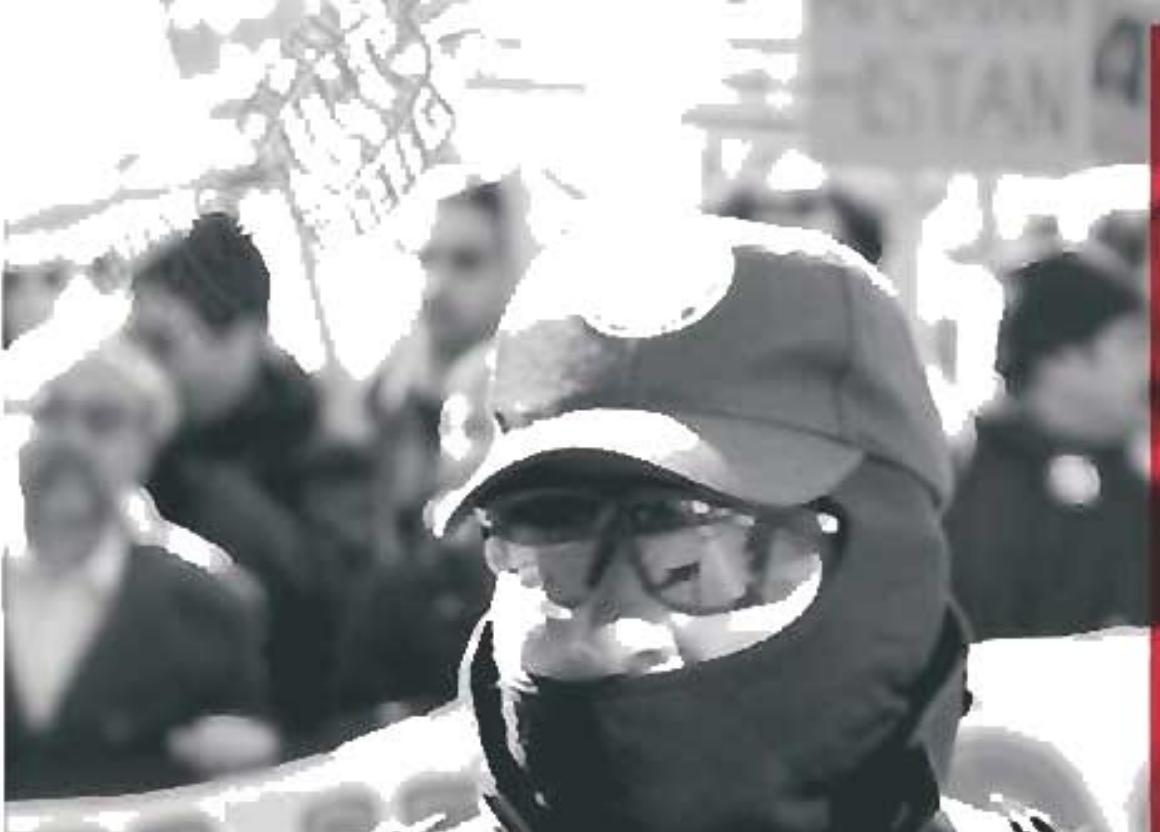

3

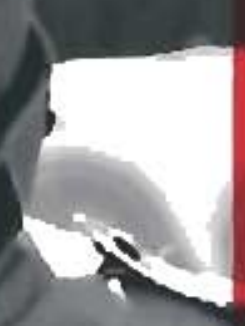

9

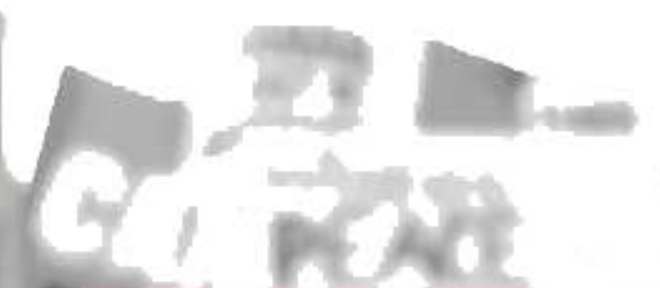

Chapter 3

Trends in National Legislative Responses to Terrorism 


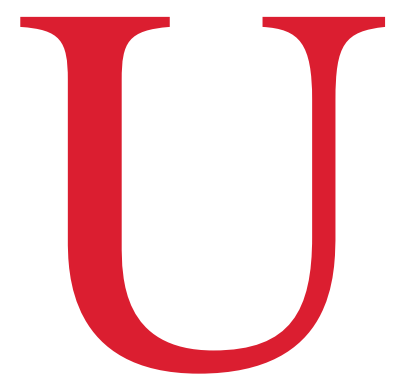

nited Nations Security Council Resolution 1373 stipulated that states must have adequate legislative provision to counter terrorism and its financing. In response, Commonwealth countries have adopted various legislative measures. Some countries have adopted new antiterrorism legislation. These laws have followed three main directions: increasing police powers; criminalising terrorism but not increasing police powers; or focussing on the financing of terrorism with no effect on police powers. However, Resolution $1373 \mathrm{did}$ not require the adoption of specific anti-terrorism legislation. Therefore, other countries decided to rely on their existing legal framework. They also followed three main paths: relying on general criminal law; relying on existing anti-terrorism law; or reviving long-standing internal security laws. Additionally, some countries have amended unrelated legislation and used it as a means of dealing with the threat of terrorism.

New laws that increase police powers have been introduced in Australia and the United Kingdom (UK). These countries have enacted hard-line laws that present security and human rights as opposing forces, rather than as complementary. The major influence of these countries means this conception has filtered out through the Commonwealth. By contrast new laws that criminalise and set out punishments for terrorist offences were introduced in Canada, Cyprus, Malta and New Zealand, without significantly strengthening police powers. ${ }^{1}$ Finally, new laws that address the financing of terrorism through money-laundering have been particularly common in Caribbean and Pacific countries of the Commonwealth such as Antigua and Barbuda, the Bahamas, Trinidad and Tobago, and Vanuatu.

Many Commonwealth members have not enacted new acts, and have relied on existing criminal and other laws instead. These include Cameroon, Dominica, Fiji, Tuvalu, Zambia and St Lucia. Some states have introduced anti-terrorism bills that have not yet been enacted, such as Kenya, Namibia and Nigeria. Others already had extensive anti-terrorism laws, such as India and Pakistan.

Yet other states have reinvigorated old security laws providing police with broad powers. The South-East Asian countries of Brunei Darussalam, Malaysia and Singapore's Internal Security Acts are legacies of colonialism, enacted in response to conflicts now over, yet currently employed to counter terrorism. ${ }^{2}$ Similarly, Botswana's National Security Act 1986 was adopted in response to the South African government's aggressive policies towards Botswana and other neighbouring countries at that time. Although widely denounced as draconian for hindering public access to information and press freedom, Botswana's ruling party has rejected calls for its abolition, arguing that it would be unwise to repeal the Act in the present context of the "global fight against terrorism". ${ }^{3}$ Lesotho and Papua New Guinea also use their existing Internal Security Acts to address terrorism.

\section{Immigration laws have been amended to enable police to detain foreigners as terrorists on weak grounds of suspicion.}

Some laws unrelated to terrorism have been amended to provide additional powers to deal with possible threats and are used in ways never originally intended. For example, immigration laws have been amended to enable police to detain foreigners as terrorists on weak grounds of suspicion. Illustratively, under their respective immigration legislation, Canada's security certificates and New Zealand's security risk certificates allowed ongoing detention without charge and significantly reduced the usual protections of due process for foreign nationals. ${ }^{4}$ Canadian certificates which could be issued on the basis of secret evidence were immediately enforceable and could not be reviewed or appealed. ${ }^{5}$ In the 2007 case of Charkaoui v Canada this indefinite detention without trial was found to be unconstitutional and to violate the 
prohibition on arbitrary detention in Canada's Charter of Rights and Freedoms. ${ }^{6}$ The government was required to rewrite this provision within a year, although it remains in force in the intervening period. ${ }^{7}$ In New-Zealand, Ahmed Zaoui was deemed a security risk on the basis of secret information and detained under the Immigration Act shortly before he was granted refugee status. ${ }^{8}$ It took five years of proceedings through the High Court, the Court of Appeal, and finally the Supreme Court to compel the Government to review the certificate. Zaoui's conditions of detention for ten months in solitary confinement and two years in a maximum security prison were described by the Court of Appeal as being oppressive and disproportionate and a denial of the due process rights to a presumption of innocence and a fair trial without delay. ${ }^{9}$ The Supreme Court granted him bail, stating that fair review of the merits of the security certificate must occur promptly. ${ }^{10}$ The review started in July 2007 and is yet to be completed. ${ }^{11}$

\begin{tabular}{|c|c|}
\hline \multicolumn{2}{|c|}{ Frequently Invoked Laws in Counter-Terrorism Policing } \\
\hline Anti-Terrorism Acts & Financing of Terrorism Acts \\
\hline Antigua and Barbuda & Belize \\
\hline Australia & Malawi \\
\hline Bahamas & National/Internal Security Acts \\
\hline Barbados & Botswana \\
\hline Canada & Brunei Darussalam \\
\hline Cyprus (via EU) & Lesotho \\
\hline Malta (via EU) & Malaysia \\
\hline Grenada & Papua New Guinea \\
\hline India & Singapore \\
\hline Jamaica & State of Emergency \\
\hline Maldives & Bangladesh \\
\hline Mauritius & General Law ${ }^{12}$ \\
\hline Nauru & Cameroon \\
\hline New Zealand & Dominica \\
\hline Pakistan & Fiji \\
\hline Samoa & Ghana \\
\hline Seychelles & Guyana \\
\hline South Africa & Kenya \\
\hline Sri Lanka (a state of emergency is declared) & Kiribati \\
\hline St Kitts and Nevis & Mozambique \\
\hline St Vincent \& the Grenadines & Namibia \\
\hline Tanzania & Nigeria \\
\hline The Gambia & Sierra Leone \\
\hline Tonga & Solomon Islands \\
\hline Trinidad and Tobago & St Lucia \\
\hline Uganda & Swaziland \\
\hline United Kingdom & Tuvalu \\
\hline Vanuatu & Zambia \\
\hline
\end{tabular}

\section{The Shaping of Legislative Responses}

Legislative responses have been shaped by a range of factors such as internal and cross border conflicts, specific catalytic events and external influences bringing both pressure and assistance to countries.

For example in South Asia, the Commonwealth countries of Bangladesh, India, Pakistan and Sri Lanka all have long histories of cross border conflicts, separatist movements, internal 
insurgencies and persistent armed social conflict. As a result, these countries have wellestablished laws to respond to terrorism which are often used indiscriminately to deal with other forms of large scale violence or persistent and entrenched anti-social elements.

The UK's history of dealing with terrorism in relation to Northern Ireland led it to enact specific counter-terrorism legislation long ago. However in 2001, shortly after the terrorist attacks in the USA and more than a decade after the situation in Northern Ireland wound down, the UK enacted the Anti-Terrorism, Crime and Security Act (2001) which enhanced police powers, including seizure of terrorist property, and most notably introduced controversial provisions allowing unlimited detention of foreigners. In 2004 the House of Lords declared that these provisions violated human rights, but attempted bombings in London in 2005 led the government to hold on to the idea of indefinite detention for terrorist suspects. ${ }^{13}$ The Prevention of Terrorism Act (2005) repealed the provisions of the 2001 Act and replaced them with control orders.

Australia's initial anti-terrorism law followed its first major experience of terrorism in the Bali bombings of 2002, where more than one third of the 202 victims were Australian. ${ }^{16}$ Similarly, Tanzania introduced anti-terrorism legislation after the bombing of USA embassies in 1998. Disturbingly, both Australia and Tanzania modelled these laws on the UK, yet failed to include the protections of the UK's Human Rights Act in the absence of an equivalent safeguard.

Other states vulnerable to external pressure caved in to the demands of powerful countries and organisations even where there has been no direct terrorist threat to themselves. Antigua \& Barbuda passed anti-terrorism legislation immediately after 11 September $2001 .{ }^{17}$ Keen to show their support for the "war on terror", this law contained direct references to Al Qaida, Osama Bin Laden and the Taliban. But visibility does not equate to effectiveness. With no history of terrorism, the timing and content of the legislation suggests it was more a measure to demonstrate support for the international community than a necessity for internal security.

\section{Control Orders to Detain Arbitrarily}

The application of control orders to terrorism suspects has provided a way of detaining people against whom there is inadequate evidence to bring charges. Control orders, under the pretext that someone might plan or commit a crime, restrict liberty through an executive order granting police powers of surveillance, electronic tagging, imposing curfew, restricting contact and movement and requiring regular reporting to the police. Since their introduction, 18 control orders have been issued on suspected terrorists. ${ }^{14}$ Yet when six of these orders were challenged, the Court of Appeal ruled that they amounted to arbitrary detention. ${ }^{15}$ Australia, Brunei Darussalam, and Malaysia also have control order regimes, and Singapore's supervision orders operate in the same way.
International pressure has come in the shape of both sanctions and incentives. The Caribbean's dependency on neighbouring countries for funding and tourism, and the development of its offshore banking industry has rendered it particularly susceptible to international pressure to adopt laws that control the financing of terrorism. Antigua and Barbuda's Prevention of Terrorism Act 2005, repealing the 2001 Act, includes in its definition of terrorism an action "designed or intended to disrupt any computer system or the provision of services directly related to (...) banking or financial services". ${ }^{18}$ Trinidad and Tobago's definition is similar. This unusual wording reflects the need to demonstrate financial security to their economic partners. These interests are also evident in the anti-terrorism laws of the Bahamas, Barbados and Grenada.

Similarly, whilst the enactment of counter-terrorism laws was not a priority for Pacific Island Countries, the possibility of using these islands as transit and financing points for terrorism raised international concern, including from Australia. Regional initiatives established as a result include the 2002 Nasonini Declaration on Regional Security which emphasised counter-terrorism and control of organised crime. Despite this regional pressure, only Nauru, Samoa and Vanuatu have adopted specific anti-terrorism legislation, and have focused on port and border security, immigration and moneylaundering rather than enhanced police powers. For example, 
in 2004 Nauru enacted money laundering and organised crime act to ensure its removal from the Financial Action Task Force blacklist. ${ }^{19}$

Whilst some international pressure has sanctioned the failure to act, other measures have directly supported states responding to terrorism. Training and technical assistance include UN Development Program capacity-building initiatives in Malaysia and Papua New Guinea; and the UN Office on Drugs and Crime's Terrorism Prevention Branch provides assistance to countries in the legal aspects of counterterrorism. The police manuals and field training of the Office of the UN High Commissioner for Human Rights and the Commonwealth Secretariat are also examples of this approach. Similarly, training and technical assistance for security was provided by Interpol, South Africa and the USA to the Caribbean countries organising the World Cup Cricket $2007 .^{22}$

The focus of international donors in Africa has seen USA funding for Kenya's counter-terrorism training through its International Military Education and Training and Foreign Military Financing programmes; and UN-led meetings between West African countries and donors to strengthen the region's counter-terrorism. ${ }^{23}$ Yet few African countries have enacted specific legislation.

\section{The Process of Legislating}

Governmental anxiety to pass strong legislation on the grounds of urgent threat - whether real or perceived - has in many instances undermined the consultative processes inherent to good law making in democracies. This is particularly important where anti-terrorism laws are concerned because they often contain provisions which have far-reaching implications for human rights. A person charged under such legislation will be liable for harsher penalties and denied certain fundamental procedural guarantees, while the police benefit from enhanced powers to gather information, detain people or use lethal force. Notably, many anti-terrorism laws create terrorism offences that attract more severe penalties than similar acts not related to terrorism. For example, in Canada a hoax is only criminalised if it relates to terrorism. It is punishable with five years imprisonment; ten if someone is harmed; and with life if resulting in death. ${ }^{24}$ In the Bahamas a "terrorist act" resulting in death is sanctioned by the death penalty, although manslaughter and murder have maximum sentences of life imprisonment. ${ }^{25}$ Similarly, anti-terrorism law can undermine long cherished safeguards for individuals against the state. For example, laws that provide for information about the grounds of suspicion and detention to be withheld from a suspect because of national security directly undermine due process. In the UK, attempts to ameliorate the effect of this provision by providing information to the suspect's lawyer breach the right to a fair trial because of the drastic restrictions on subsequent contact between the lawyer and their client. ${ }^{26}$

Because they impact so negatively on even deeply entrenched rights and liberties, such legislation requires deep consideration, wide consultation and careful review by expert committees before they can pass into law. But in many cases due deliberation has been sacrificed to haste.

In Australia the Anti-Terrorism Act (2005) was passed on a public holiday when the entire nation was engrossed in a national sporting event. Controversial for broadening the scope of several 


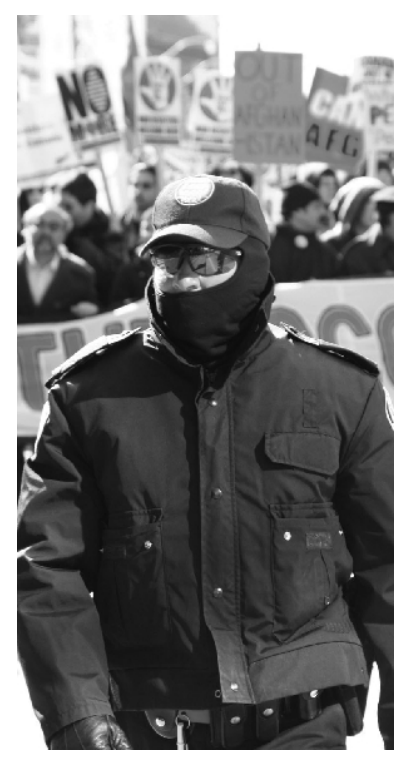

terrorism offences already in the Criminal Code, the amendment was presented as an urgent response to an imminent threat. In the UK, despite intense opposition, the Anti-Terrorism, Crime and Security Act (2001) was rushed through parliament in less than a month; and the later Prevention of Terrorism Act (2005) was passed in similar fashion. Canada's Anti-Terrorism Bill C-36, which gave new powers of arrest and detention to police, was introduced just 17 days after UN Resolution 1373 was passed. Drafted without comprehensive external consultation, it sped through parliament and was passed two weeks earlier than its scheduled introduction. The Tanzanian Prevention of Terrorism Bill was enacted in 2002 less than one week after it was introduced, with neither public debate nor sufficient parliamentary scrutiny.

Elsewhere pre-legislative scrutiny of anti-terrorism legislation has produced stronger compliance with human rights, as in the case of New Zealand. Here, anti-terrorism legislation has been enacted without a consequent reduction in human rights in part because many concerns of civil and human rights groups, in submissions to Parliament, were incorporated in the redrafting of the final Acts. ${ }^{27}$ For example, the definition of a terrorist act was tightened and judicial review of any designation of an organisation as terrorist was reinstated. ${ }^{28}$ The legislative drafting committee's chairman stated:

"It was clear [from the submissions] that we needed to make some changes to the bill that took into account people's rights and civil liberties, and took into account the legislation that had been passed in Canada, the United States, and the United Kingdom. We had to look at better ways of legislating than they did, because we were not satisfied that there were enough protections for people". ${ }^{29}$

Similarly, in South Africa, the highly controversial Anti-terrorism Bill (2000) proposed expansive powers for police to stop and search vehicles and persons and to detain to interrogate individuals suspected of withholding information. ${ }^{30}$ For the next four years the Bill was debated and controversial provisions such as 14-day detention for interrogation were abandoned in the final Act. ${ }^{31}$ Even bombings at Kenya's USA embassies in 1998 and 2002 did not assuage outcries from the public and civil society at its attempts to introduce harsh counter-terrorism legislation, which were successively rejected.

Strong criticism from civil society about systemic police abuse of existing legislation can lead to its review or repeal. However, this does not prevent the state re-enacting similar harsh provisions in other forms. In India drastic counter-terrorism police powers granted by the Terrorist and Disruptive Activities Act (TADA) were re-enacted in the subsequent Prevention of Terrorism Act (POTA). ${ }^{32}$ When gross abuses under POTA led to its repeal, many of its controversial provisions were reintroduced in India's main anti-terrorism law, the Unlawful Activities Prevention (Amendment) Act (UAPA). ${ }^{33}$

Another device to avoid contentious debate over civil liberties concerns and downplay the real and negative impact of anti-terrorism laws has been to suggest that the measures are temporary and include sunset clauses. These allow laws created in specific contexts to lapse after a certain time or subject them to periodic review and considered renewal. In Canada, anti-terrorism provisions introduced with a sunset clause in the Criminal Code (2001) lapsed in March 2007 and were not renewed. ${ }^{34}$ Yet these seemingly temporary measures can be extended, and what was once presented as extraordinary becomes ordinary. In Australia many provisions of the Anti-Terrorism Act (2002) were set to expire in 2005. At the time of expiry the Australian government re-enacted them in new anti-terrorism laws which are now due to sunset in 2010.

\section{Unfettered Discretion: a Problem of Definition}

The UN Counter-Terrorism Committee monitors the adequacy of national laws to counter terrorism and its financing. However, their compliance with human rights requires much greater attention. The UN Special Rapporteur for counter-terrorism and human rights has asserted that in 
the field of counter-terrorism, "human rights conformity must be seen as one of the defining characteristics of 'best practice'.", Counter-terrorism and human rights are complementary. The combined effect of lack of consultation and haste in creating legislation has resulted in weakening people's protection against abuse of human rights by state actors while at the same time enhancing their powers and discretion, especially those of the police. Due to their strong effect on human rights, these laws must contain safeguards, including provisions providing a clear scope of application for the law and a clear meaning for the concepts used. The inability of the international community to settle on a definition of what amounts to terrorism or a terrorist act, and the strong pressure cast on Commonwealth countries to adopt legislation, impacted significantly on these safeguards.

Definitions of terrorism vary throughout the Commonwealth. All states name actions which they outlaw as terrorism, such as causing injury, death or damage to property. Some require a specific intention to commit terrorism in addition to the action. For instance the intention to advance a political, ideological or religious cause is in Australia's definition of terrorism. ${ }^{36}$ In Samoa, a terrorism offence includes "intimidating the public or a section of the public ... with the intent to cause public alarm, fear or panic." ${ }^{, 37}$ Additionally, some laws have specifically excluded certain actions which will not amount to terrorism. Australia, New Zealand, the Seychelles and Vanuatu have all included exceptions in their anti-terrorism laws. For instance, Seychelles legislation states that:

"An act which disrupts any services and is committed in pursuance of a protest, demonstration or stoppage of work shall be deemed not to be a terrorist act within the meaning of this definition so long and so long only as the act is not intended to result in any harm (...). ${ }^{, 38}$

All three elements of action, intention and exception are contained in the Commonwealth's Model Legislative Provisions on Measures to Counter Terrorism (model law). These provisions were designed by the Commonwealth Secretariat to provide counter-terrorism guidance and promote legal uniformity throughout its member states. ${ }^{40}$ It was used by the UN Office on Drugs and Crime Terrorism Prevention Branch in its assistance to UN members with common law systems. Unfortunately, although the drafting body considered the human rights obligations of the Commonwealth in their deliberations, there is no evidence of this in the model law. ${ }^{41} \mathrm{~A}$ number of Commonwealth countries contain definitions close to the model law, including Antigua and Barbuda, Fiji, Kenya, Kiribati, the Seychelles, Singapore, Tanzania, and Vanuatu. But none are identical and few refer to international conventions or have exceptions clauses. ${ }^{42}$

Even where they include all three elements of definition in the model law, the definitions of terrorism used throughout the Commonwealth fail to meet the criteria of legal certainty. For example, carjacking is a common occurrence and criminalised the world over. But the Maldives Prevention of Terrorism Act also lists it as a terrorist act requiring no element of intent to distinguish it from ordinary theft. ${ }^{43}$ This makes the prosecution of carjacking a discretionary decision by police who may treat it as an everyday crime, or as terrorism where the suspect will subjected to lower protections of due process, longer periods of detention without trial, will be judged on lower standards of guilt and

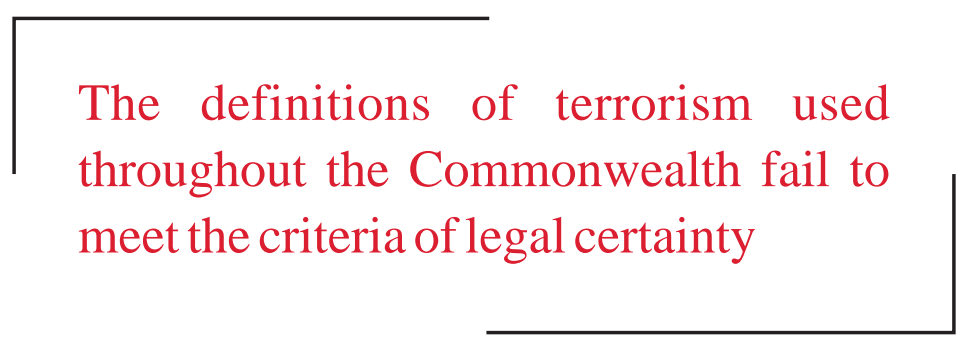
will be liable for harsher penalties than general criminal law and procedure. Similarly, in Malaysia merely possessing or using a firearm without due authorisation is proscribed as an act of terrorism. ${ }^{44}$ Merely listing actions usually associated with terrorism, such as murder, injury and bombings that are already prohibited by criminal law, without qualifying how they become acts of terrorism, subjects suspects to uncertainty as to whether they will be charged under terrorist or regular criminal law. 


\section{Definition of Commonwealth Model Legislative Provisions on Measures to Counter Terrorism (model law) ${ }^{39}$}

(1) an act or omission in or outside a counter terrorism convention;

(name of country) which constitutes an offence within the scope of

(2) an act or threat of action in or outside. (name of country) which -

(a) involves serious bodily harm to a person;

(b) involves serious damage to property;

(c) endangers a person's life;

(d) creates a serious risk to the health or safety of the public or a section of the public;

(e) involves the use of firearms or explosives;

(f) involves releasing into the environment or any part thereof or distributing or exposing the public or any part thereof to -

(i) any dangerous, hazardous, radioactive or harmful substance;

(ii) any toxic chemical;

(iii) any microbial or other biological agent or toxin;

(g) is designed or intended to disrupt any computer system or the provision of services directly related to communications infrastructure, banking or financial services, utilities, transportation or other essential infrastructure;

(h) is designed or intended to disrupt the provision of essential emergency services such as police, civil defense or medical services;

(i) involves prejudice to national security or public safety;

and is intended, or by its nature and context, may reasonably be regarded as being intended to -

(i) intimidate the public or a section of the public; or

(ii) compel a government or an international organization to do, or refrain from doing, any act, and

[Optional-[(iii) is made for the purpose of advancing a political, ideological, or religious cause.]

(3) An act which -

(a) disrupts any services; and

(b) is committed in pursuance of a protest, demonstration or stoppage of work, shall be deemed not to be a terrorist act within the meaning of this definition, so long and so long only as the act is not intended to result in any harm referred to in paragraphs, (a), (b), (c) or (d) of subsection (2).

This lack of clarity means that people cannot know what behaviour is outlawed; police cannot effectively investigate offences or lay the appropriate charges against offenders; and oversight bodies cannot monitor police conduct in light of clearly stated boundaries of permissible behaviour. Where the decision about whether an act is criminal or terrorist is left in the hands of police it creates unfettered discretion which is bound to lead to abuses, especially in the highly charged contemporary climate of anti-terrorism.

Legal certainty requires that legislators identify what makes a crime an act of terrorism when they intend to create specific terrorism offences. Most Commonwealth countries attempt this by coupling intention with action. However, often intention to commit terrorism is defined so broadly that it encompasses elements of legitimate democratic process such as mass rallies or public protests against government policies. Under broad or ill-defined definitions most actions in opposition to government can amount to terrorism if they seek to influence government or are done for the purpose of advancing a political cause. This also risks losing the distinction between the crime of terrorism and lawful actions such as lobbying, demonstrating or simply being sympathetic to the political opposition. This blurring allows the police to use their enhanced antiterrorism powers in many situations that do not warrant such extraordinary intervention. 
Although uncommon in Commonwealth countries, exception clauses seek to limit this misapplication of anti-terrorism laws by listing or excluding actions that do not amount to terrorist activity. However, their scope is very narrow, covering only the disruption of a service linked to a protest, demonstration or work stoppage. Even when enacted, exceptions have not prevented the extension of counter-terrorism policing to lawful practices or the policing of public order. Damage to property and personal injury are frequent during demonstrations and do not fall under the scope of exceptions clauses, nor does lobbying.

Broadly defined offences have also been coupled with a reversal of the burden of proof. For example in the UK, the "collection or possession of information likely to be useful to a person preparing or committing an act of terrorism" is a terrorist offence. ${ }^{45}$ The mere fact that the information could be useful to a terrorist is grounds for suspicion. The challenge of disproving this is made even harder because, contrary to general procedural law, the onus is on the accused to prove that the information was not for the purpose of terrorism.

Some anti-terrorism legislation also includes criminal acts listed as a specific terrorist offence even though the activity does not match the definition enshrined in the same law. For example the Pakistani Anti-Terrorism Act classifies gang rape, child molestation, or robbery coupled with rape as terrorism offences. ${ }^{46}$ Whilst these are clearly abhorrent criminal acts, it is not clear how or why they should be codified as terrorist acts in the absence of terrorist intent, which is required by the definition of terrorism in the same Act. ${ }^{47}$

In the absence of clear laws, police must determine on a case-by-case basis when, how and to whom these laws should be applied. Such laws, based on police discretion, reduce the potential for oversight by courts and other accountability bodies, thereby creating an environment favourable to police misconduct and human rights abuses. In their failure to enact good, clear legislation, lawmakers are complicit in police abuses that result from these unrestrained powers.

Guaranteed rights and freedoms fall victim to broad definitions, unrestrained police discretion and catch all legislative design, frequently utilised to further internal agendas and politically motivated policies. In Uganda for example, after the passing of the Anti Terrorism Act (2002) the Museveni government designated the rebel group People's Redemption Army as a terrorist organisation, labeled opposition leader Kizza Besigye as a terrorist by linking him to that group, and then announced a ban on all speeches, demonstrations or media expressing support for Besigye. The government went on to issue routine threats to media agencies that dared interview Besigye with prosecution under antiterrorism law that carries the death penalty for anyone who "publishes or disseminates materials that promote terrorism." 49

Increasingly, across the Commonwealth people exercising their democratic right of peaceful assembly, freedom of association, and freedom of expression are being considered as threats to public order, and often as terrorists. Although violence and physical force in protest are disruptive and may be criminal acts, labelling them as terrorist is a misuse of the law. Malaysian police continue to classify those expressing opposition to the government as threats to security and public order. Using the Internal Security Act, the police can detain a person who falls under the broad scope of having acted or being likely to act in "any manner prejudicial to the security of 
Malaysia or any part thereof or to the maintenance of essential services therein or to the economic life thereof., ${ }^{, 50}$ Police can detain a person for 60 days, which the Minister can extend for a further two years detention without judicial review. Over the years, the Act has been consistently used to detain political opponents. ${ }^{51}$

Police often use extraordinary methods to control ordinary actions. Counter-terrorism policing is deliberately used to cast a chill over those participating in legitimate, democratic expression, by subjecting people to the knowledge that they could be arrested and detained under harsh antiterrorism regimes. For example, Australian anti-terrorism police have been increasingly involved in controlling demonstrations. ${ }^{52}$ Specially trained anti-terrorism squads have not only been used to police public order at demonstrations, but to conduct raids, searching private property and arresting people for their participation in these rallies. In March 2007, the Victorian anti-terrorism squad teamed up with federal and state police and carried out dawn raids and arrests at the homes of four university students, arresting them from their beds. The students had participated in a large public protest that involved violent clashes between protestors and police at the G20 meeting in Melbourne in 2006. ${ }^{53}$ The use of specially trained anti-terrorism police was neither necessary nor proportionate to the nature of the activities the students were involved in.

The right to free association is also jeopardised by the lack of clarity and consistency around decisions to proscribe organisations. Whilst states have the right to proscribe terrorist organisations, there must be justifiable grounds. But frequently nothing more than an executive order forms the basis of this decision. The right of states to proscribe an organisation does not deny the organisations the right to due

"Fear of terrorism out of proportion to its actual risk and generated either by States themselves or

by other actors can have undesirable consequences such as being exploited to make people willing to accept counter-terrorism measures that unduly curtail human rights and humanitarian law. Undue fear can foster religious or ethnic intolerance. Exploitation of fear of terrorism can also damage international solidarity, even to the degree of impairing cooperation regarding reducing or preventing terrorism."

Kaliopi Kouffa, UN Special Rapporteur on Terrorism and Human Rights ${ }^{56}$ process. This was confirmed by the European Court of Justice when it overturned the European Union's proscribing of the People's Mujahedin of Iran on the grounds that the process denied the suspect group the right to submit evidence on its own behalf and participate in the proceedings. ${ }^{54}$ Due process and transparency over the process of proscription is particularly important as people associated with a banned group automatically become subject to suspicion and police scrutiny.

Equally, under Sri Lanka's Emergency Regulation, members of the press have been repeatedly treated as enemies of the state for questioning or criticising the government, for reporting on Tamil issues or disseminating Tamil-language news. ${ }^{55}$

All in all, the trends in Commonwealth anti-terrorism legislation indicate a willingness by governments to legislate all too easily on an issue they cannot precisely define or delimit. Pressured by various internal or external factors, states have tended to abdicate their overarching and premier duty to protect not only the security of their people but also their rights and freedoms. Instead there is a ready willingness in governments to garner extraordinary powers to themselves and clothe state agencies and particularly the police with powers that they are then often unable or unwilling to oversee or curb. In many countries measures taken in the name of countering terrorism are alienating populations. All too often they are used to stifle the democratic urge while privileging the authoritarian impulse and so end up assisting in achieving the very aim that anti-terrorism laws are designed to discourage in the first place. 


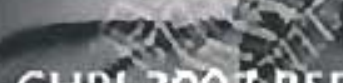

\section{CHRI 200 TREPORT}

sicropit?

The impact of anti-terrorism laws on policing c)e
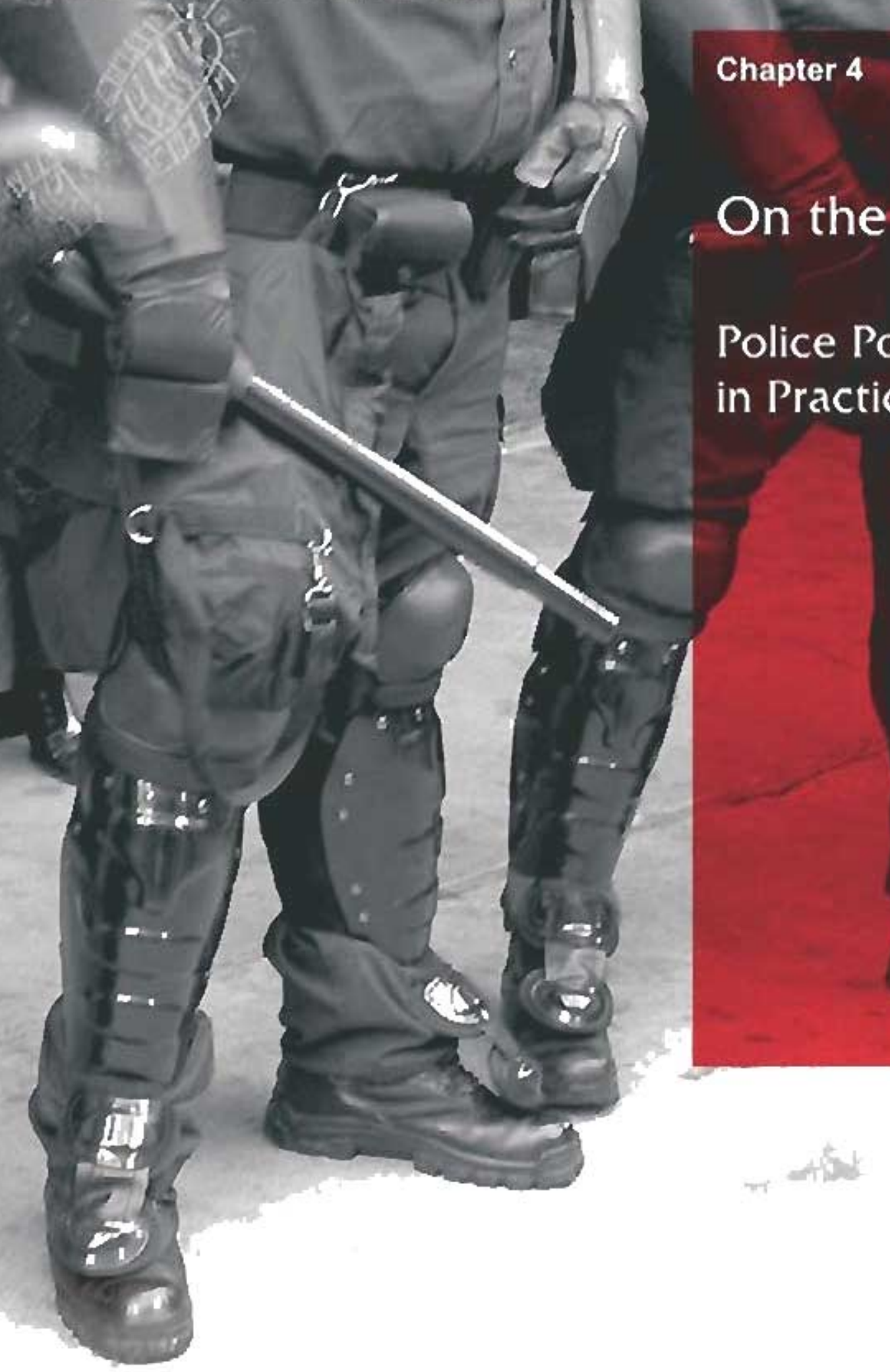

Chapter 4
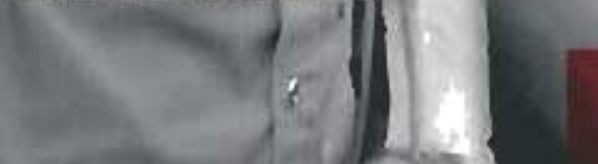

\section{On the Ground:}

Pers

- 


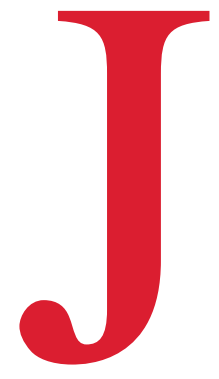

ustified by the possible or perceived threat of a terrorist attack, many jurisdictions have enhanced police powers and extended discretion to forces already known to be arbitrary and discriminatory in their functioning and disobedient to the laws that govern civilian policing. Even in countries where police are carefully monitored, grave concerns remain about the scope and extent to which police powers have expanded because of the way in which they have been used and their potential for abuse.

In an effort to contain the possible harm caused by terrorism, states have introduced extensive and deeply invasive measures at the sacrifice of long-standing, inviolable rights and freedoms. In turn, fear created by both terrorism and the international climate has put pressure on police to be seen to respond to terrorism and has licensed police action that ultimately is not compatible with the rule of law. The slightest suspicion, however unfounded, now permits police to stop and search, monitor, investigate, question, arrest, and detain.

\section{Big Brother Policing: Surveillance, Stop and Search, and Profiling}

\section{Surveillance}

In the name of counter-terrorism the Commonwealth has witnessed an increasingly visible police presence, heightened surveillance, and provisions in anti-terrorism legislation that aim to prevent an attack on national security but have resulted in big brother policing, where the community at large is under constant surveillance. Good and reliable intelligence is crucial to counter terrorism, however there is a fine line between gathering intelligence and invading the right to privacy.

\section{No one shall be subjected to arbitrary or unlawful interference with his privacy, family, home or correspondence. Article 17, ICCPR}

In India, surveillance has developed to the point of unrestricted interception of communication. ${ }^{1}$ Preexisting safeguards have been discarded so that police no longer have to justify the encroachment on the right to privacy. $^{2}$ The law allows information extracted through interception, without authorisation, to be admitted as evidence in court. ${ }^{3}$ Constant surveillance is often seen as a key to security, and police and private CCTV frequently provide police with the circumstantial evidence they need to build cases. Following the 2005 bombing in the UK, the police broadcasted CCTV recordings, and received information from more than 500 viewers. More recently CCTV has played an integral part in the attempted bomb attacks in London and Glasgow. However, despite its laudable purpose, it threatens to create a "surveillance society" where privacy becomes a luxury and the sharing of personal data becomes the norm. ${ }^{4}$ In the United Kingdom for example, there is an average of one camera with an eye on every fourteen people.

\section{Stop and Search}

Stop and search powers in anti-terrorism laws often include invasive procedures. In Australia these powers allow for measures such as strip search, however this power is tightly controlled through senior authorisation in each instance and can only be granted on the basis of an imminent threat. ${ }^{7}$ In the UK law permits police officers to stop and search any person in order to find any object "of a kind which could be used in connection with terrorism." ${ }^{8}$ This power can be exercised even if the officer has no grounds to suspect that person has any such objects. Illustratively, a demonstrator on his way to an international arms fair was stopped
"Intelligence led policing, not stop and search, is necessary to detect and prevent terrorism.",

Sir Menzies Campbell, leader of the Liberal Democrats (UK) 
and searched by police, along with a journalist on her way to take photos. ${ }^{9}$ There was no reason to connect them with anything illegal, yet the procedures conducted under anti-terrorism powers can hardly be questioned at law because there is no need for police to justify their suspicion. ${ }^{10}$

Powers of stop and search have led to very few convictions of terrorists yet proposed new laws imposing a heavy fine on anyone refusing to reveal their name and other information on request suggests this practice is likely to remain. ${ }^{11}$ It is of great concern that the disproportionate use of stop and search has resulted in deep alienation of Muslim communities whose members are increasingly targeted as terrorist suspects. Yet the UK Minister responsible for counter-terrorism was sanguine in her admission that "Muslims will have to accept as a reality that they will be stopped and searched by the police more often than the rest of the public."12

\section{Terrorist Profiling}

Profiling is a formalised scientific method of attaching statistical probabilities of likely behaviour to particular populations using criteria such as race, ethnicity, gender and religion. Profiling has been criticised for reinforcing discrimination and racist stereotypes. In counterterrorism policing, profiles are used as tools to attach suspicion to particular communities which are then targeted for special attention by police practices such as stop and search. The broad powers to stop and search without grounds, coupled with institutional bias have frequently been criticised for demonstrating police prejudice, and ethnic minorities and young people are over-represented in the so-called random process. ${ }^{13}$ In the UK, people of Asian descent are $30 \%$ more likely to be searched than a white person. ${ }^{14}$ The UN Special Rapporteur agrees that profiling can be an effective means of law enforcement, however cautions that, "profiling based on stereotypical

The Commonwealth Harare Declaration demands equal rights for all. It sees "racial prejudice and intolerance as a dangerous sickness ... and racial discrimination as an unmitigated evil.", assumptions that persons of a certain 'race', national or ethnic origin are particularly likely to commit crime may lead to practices that are incompatible with the principle of non-discrimination."

However flawed their underlying premise, the scientific method of profiling ensures a process guided by policy and procedures that are reviewable and often come under close scrutiny. In the UK these issues are well documented and can be addressed through constant scrutiny and reform. But this is not the case across the Commonwealth. The laws and practices of other jurisdictions do not undergo such scrutiny and the weight of unchecked discretion falls heavily on targeted communities who already suffer from stereotyping about their proclivities towards crime or terrorism.

In Kenya, counter-terrorism operations performed by the Anti-Terrorism Unit and the Kenyan Police Force have been executed in particular areas where many Ethiopian and Somali refugees reside, and arrests of Muslims and residents of Somali descent but Muslim faith have led to detention for periods exceeding the legal limit. ${ }^{17}$ Often held incommunicado and with little legal safeguards to protect them, many have been summarily thrown out of Kenya in what appears to be a joint rendition operation by anti-terrorism forces from Kenya and the USA. Since December 2006 at least 85 people including a Canadian national have been subject to this procedure and have been sent to either Somalia or Ethiopia. The whereabouts of many remain unknown. ${ }^{18}$ 


\section{Unwarranted Arrest}

Anti-terrorism legislation often enlarges police powers of arrest either in general or in particular circumstances. But sometimes the circumstances themselves are so broadly defined that they leave too much discretion with the arresting agency. For instance in Tanzania police powers to arrest without warrant, enter and search premises, stop and search people and seize property using

\section{The children of Jharkhand}

Jharkhand, a small state in central India has a history of extremist violence involving armed groups in contention with state forces. The police frequently detain very young children on "suspicion" of associating with extremists but often only to get information or pressure families to cooperate. Vinod Singh, 12, was on his way to graze cattle when he was caught by police, badly beaten and arrested. Detained for alleged connections with terrorists, the only grounds for suspicion were that he lived in a community where there was an active extremist cell. ${ }^{23}$ Mayanti Kumari, 14, was arrested on suspicion of being a terrorist. The police failed to file the charge sheet required by law and her parents were not informed of her detention in a police cell. ${ }^{24}$ Fourteen year-old Janaki Bhuia's only crime was guilt by association with his father who had suspected links with extremists. Despite not having seen his father for the past three years. Janaki was pulled from his bed by dozens of police, arrested and detained under POTA. ${ }^{25}$ This terrifying form of hostage taking, dressed up as a valid arrest on suspicion, illustrates how anti-terrorism legislation in fact plays out in jurisdictions where there are weak mechanisms of accountability, vulnerable populations and wide discretionary powers in the hands of police.

"such force as may be necessary" extend only in case of "urgency". ${ }^{19}$ However urgency remains undefined and leaves the justification of actions to the discretion of the police officer. Even the Commonwealth model law includes a provision to arrest without warrant, yet neither it nor the laws of many countries provide a process for reviewing the appropriateness of arrest as a necessary safeguard against police arbitrariness and bias.

Already harsh anti-terrorism legislation in India has been compounded by successive laws. These have created new offences, made bail difficult, reduced fair trial guarantees, enhanced penalties and established special procedures to try terrorist suspects. ${ }^{20}$ Even as one law has been repealed in the face of severe criticism, its restrictive and overly broad provisions have appeared in the next. The Terrorist and Disruptive Activities (Prevention) Act was hurriedly replaced by the Prevention of Terrorism Act (POTA) after the 2001 attacks in the USA. With little right of appeal or review for detained suspects, POTA seemingly appeared to license police to act as they wished. The Unlawful Activities Prevention Amendment Act (UAPA), POTA's successor and India's key current anti-terrorism law, simply reinforces repressive powers for police to arrest, detain and interrogate individuals without charge or trial. The controversial special courts have been carried over to the new legislation. ${ }^{21}$ Additionally, people who may have been wrongly arrested under the now repealed POTA remain incarcerated for years while awaiting trial in a judicial system infamous for the number of criminal cases in arrears. 
The consequences of licensing policing with these kinds of powers in a country where there is already enormous public concern about abusive policing are inevitable. In one typical case, anti-terrorism police carried out a mass arrest of 200 people from a poverty-stricken rural area for their alleged association with an extremist group operating in the district. The community had been in conflict with the government over use of land and forest resources, which has been attributed as motivation for this sweeping demonstration of police power. The indiscriminate arrests included children as young as twelve and people over the age of $80 .{ }^{22}$

In other instances the wide discretion and powers given by India's anti-terrorism laws have been used to make up for the absence of good intelligence gathering. Faced with extremist violence and public alienation police have often been cited for using the powers under anti-terrorism laws to pressure communities through practices themselves akin to terrorism.

In Pakistan arbitrary arrest under anti-terrorism legislation has led to the actual disappearance of suspected terrorists. Usama Bin Youssef, possibly a Pakistani or Saudi national, was accused of being linked to al-Qaeda and of storing digital information in preparation for a terrorist attack. ${ }^{28}$ Arrested in Faisalabad in 2005 and allegedly interrogated by US officials, Bin Youssef has since disappeared. ${ }^{29}$ In similar circumstances an Afghan national, Imran Munir, was arrested in Islamabad in 2006. He was allegedly taken by Pakistan's Inter-Services Intelligence agency (ISI) and never returned home. ${ }^{30} \mathrm{~A}$ habeas corpus petition filed by his father produced an official denial of his custody. He has not been heard from since his arrest. ${ }^{31}$ The phenomenon of disappearing terrorism suspects is so concerning that it prompted a report into those who have disappeared after being arrested or (often secretly) detained. ${ }^{32}$ Bin Youssef is one of those listed.

\section{Due Process Safeguards in Arrest}

To reduce the widespread practice of illegal detention at police stations, the Indian Supreme Court set out twelve clear guidelines for police throughout India to follow in all cases of arrest. These include procedural safeguards that insist:

- police carrying out the arrest wear accurate and visible identification tags and all police involved in any interrogation be recorded in a report;

- the arresting police officer prepare a memo at the time of arrest to be attested by a family or respected community member and countersigned by the arrested person;

- a copy of the memo of arrest be sent to the magistrate; and

- the person arrested be made aware of his right to inform someone of his detention immediately after the arrest or detention. ${ }^{26}$

These procedures must be adhered to in all counterterrorism policing.

The court said: "state terrorism is no answer to combat terrorism. State terrorism would only provide legitimacy to terrorism: that would be bad for the community, the State and, above all, the rule of law. The State must, therefore, ensure that the various agencies deployed by it for combating terrorism act within the bounds of law and not become a law unto themselves. ${ }^{27}$

Many safeguards in arrest procedures are threatened by counter-terrorism policing. Once arrested the detainee often has no information about the grounds for arrest and may be unable to contact a lawyer or family member. Special powers granted for the investigation of terrorism offences in Australian security and intelligence legislation severely restrict the minimum guarantees of the right of the person arrested to access legal counsel, where suspects detained before charge can be prevented from contacting a lawyer of their choice, questioned without a lawyer present and the lawyer can be restricted from intervening at any time. ${ }^{33}$

\section{Serving Time: Human Rights Behind Bars}

\section{Preventive detention}

Preventive detention provisions exist in criminal law. They are justified as a means of protecting the public from imminent danger or a means of preventing criminal activity, which can reasonably be discerned from the behaviour or circumstances surrounding the detention. 


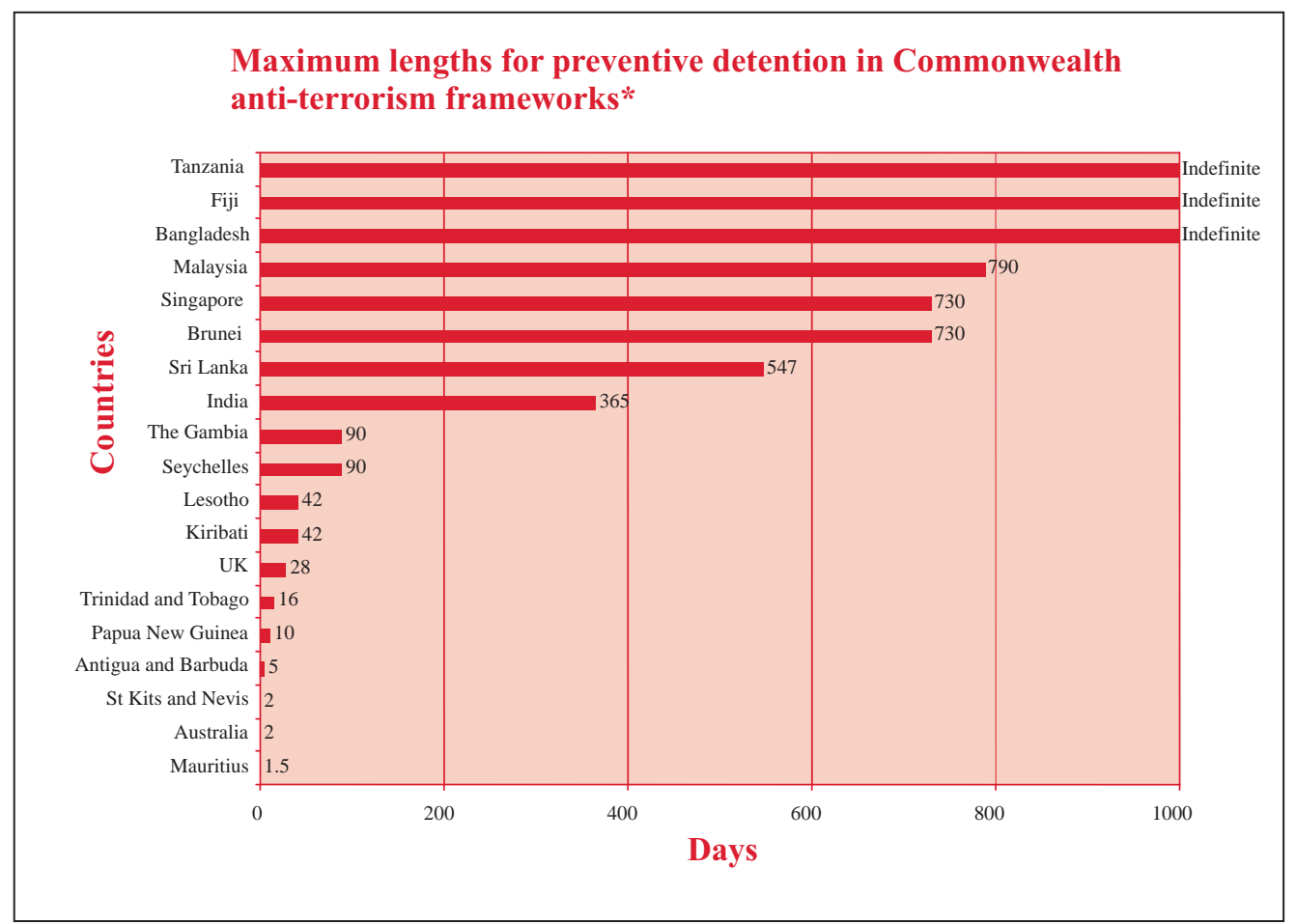

*'Anti-terrorism frameworks' include specific anti-terrorism laws and other laws that make specific reference to terrorism. 1000 days represents indefinite detention.

Preventive detention has always been seen as an evil necessity that must be used sparingly. The basis of suspicion must be well grounded in logic and reason and periods of preventive detention must be minimal. Many anti-terrorism laws now include wider preventive detention clauses or extend periods for which people can be preventively detained. Even in the context of security, preventive detention can never be arbitrary and must always be lawful, reasonable and necessary under the circumstances. For example it may be justified if required "to prevent flight, interference with evidence or the recurrence of crime." ${ }^{34}$ However preventive detention has become a key counter-terrorism tool to hold suspected terrorists for extended periods of time without charge or sufficient reason.

Often preventive detention can be renewed by court order. This leads to lengthier and indefinite periods in detention under anti-terrorism law. Bangladesh, Fiji and Tanzania allow infinite extensions of custody. ${ }^{1}$ Malaysia and Singapore also have harsh regimes, each allowing for over 700 days preventive detention. ${ }^{2}$ In the UK concern at the elasticity of preventive detention provisions forced the government to reduce its original bill for 90 days to 28 days. ${ }^{3}$ However the proposed introduction of new tough anti-terrorism laws is likely to include a reversal of this decision. $^{4}$

In 2001 the UK introduced controversial indefinite detention provisions for foreign nationals suspected of terrorist acts. ${ }^{5}$ Egyptian national $\mathrm{C}$ was detained for three years for being a prominent member of a Jihadi group in the UK. ${ }^{6}$ Detained without charge or trial, he was eventually released with no further explanation. C's solicitor said that the decision had come "completely out of the blue" and amounted to an admission that $\mathrm{C}$ was "no danger to anyone at all." This provision so blatantly contravened the European Convention of Human Rights that it was repealed in 2005. 
The consequences of taking people into custody without cause, for long and renewable periods of detention, are made even direr by many laws that restrict access to counsel, effectively prevent judicial review of executive action and seek to suspend even the right of habeas corpus. Under Australian law the detainee is prohibited any access to legal counsel. ${ }^{8}$ The legislation also prevents judicial review of executive decisions relating to the preventive detention of terrorist suspects. ${ }^{9}$ In Singapore, there is no obligation to disclose the grounds for detention if the public servant considers that not disclosing them serves the public interest, nor any prescribed judicial review of that detention. ${ }^{10}$

\section{Investigative detention}

Detention is increasingly used to interrogate both suspects and non-suspects to obtain terrorismrelated information or to allow the police the required time to gather evidence required to charge the suspect, for example, through investigating complex intelligence, international links or deciphering encrypted information. Under Australian criminal law police could already interview terrorism suspects for up to four hours but anti-terrorism amendments extended this to 20 hours by magistrate's order. Rest and meal breaks are excluded from this interview time and police can "stop the clock" and apply for extensions of time as they carry out further investigations, potentially resulting in custody that lasts for several days or weeks. ${ }^{11}$

Under Australian security and intelligence legislation, a person who may merely have information about a terrorist act can be detained for long periods of interrogation. Such non-suspects can be brought into custody for the purpose of investigating a terrorism offence, can be questioned for up to 24 hours without an interpreter, and detained for up to 168 hours (seven consecutive days). ${ }^{12}$ The Attorney-General must authorise the warrant, but once issued the detained person is obliged to answer all questions, undermining the right to silence and to freedom from self-incrimination. Additionally access to justice is seriously threatened through limited legal representation and stricter control over contact with family. ${ }^{13}$ Both the UN Special Rapporteur on human rights and counter-terrorism and the International Commission of Jurists have voiced serious concerns about these provisions. Criticising the Australian legislation for jeopardising the right to a fair trial and for failing to provide for determination by an independent judicial authority, they have urged its revision to ensure that "security measures, including those taken to counter terrorism, correspond to the international human rights framework.", 14

\section{Exceeding the Limit: the Unreasonable Use of Force}

The state has a monopoly on use of force. For this very reason, legitimate use of force is carefully regulated by national and international law.

Unfortunately there are many examples in the Commonwealth of counter-terrorism police using excessive force in the exercise of their extended powers. In Mombasa (Kenya) in April 2007, over 50 Anti-Terrorism Police and General Service Unit Officers carried out a "commando-style" dawn raid taking suspected terrorists from their beds and arresting them without search warrants. ${ }^{16}$ The houses were ransacked while the Unit reportedly shot without provocation, beat up suspects and took money and jewellery. ${ }^{17}$ Since the raid, ten of the arrested suspects have been unconditionally released, suggesting that the force used was not only excessive and disproportionate but also unwarranted. ${ }^{18}$
"Without question, the State has the duty to guarantee its security. However, regardless of the seriousness of certain actions and the culpability of the perpetrators of certain actions and certain crimes, the power of the state is not unlimited, nor may the State resort to any means to attain its ends."

Inter-American Court of Human Rights on the guaranteed right to life contained in the American Convention of Human Rights (1988) ${ }^{15}$ 
Abuse of police powers can be reduced through stringent limitations on the use of force. Most anti-terrorism laws stipulate that police officers may use such force as is necessary and reasonable. For example, the Internal Security Acts of Brunei Darussalam, Malaysia and Singapore allow police to use lethal force in arrest or to prevent the escape of a suspect from custody but only if it is "necessary" in the circumstances. ${ }^{19}$ In Sierra Leone, which has not yet enacted anti-terrorism legislation, the nation's constitution expressly limits the person's right to life if their death is "reasonably justifiable" in the process of lawful arrest or detention or preventing the commission of a criminal offence. ${ }^{20}$

Standards of what is "reasonable" and "necessary" require discretionary determinations of whether force used is proportionate to the threat. Such assessments are likely to be influenced by the heightened atmosphere of insecurity and fear that underpins counter-terrorism policing. Disturbingly, some laws do not even require force to be reasonable. For example, the Internal Security Act of Lesotho allows for any force in stopping and searching and detention that can "extend to causing injury to that person". ${ }^{21}$

The most important check on the use of force is to ensure police are accountable for their actions. Yet there have been direct removals of this check on anti-terrorism policing. For example, Indian law prohibits legal proceedings to be taken against police officers if the action is "purported to be taken in good faith", a claim which is practically impossible to disprove. ${ }^{22}$ In a positive step, the immunity provision in Kenya's original anti-terrorism bill which excluded police officers from liability for injury or death in the exercise of their powers has been removed in the current draft Bill. $^{23}$

\section{Strange Encounters of the Policing Kind}

The urgency to counter terrorism through extraordinary measures and specific anti-terrorism legislation has created many distortions in policing. The police are under constant pressure from the state and public to act swiftly and secure the public's safety at all costs. Under such pressure mistakes happen, and too often they are fatal. In the heightened tension following the London bombings in July 2005 Jean Charles de Menezes, a young Brazilian man, was followed by police as he made his way to the tube station. He was pursued by the officers on to a train, held down and shot eight times. Initially police claimed de Menezes was a suspect linked to the failed bombings of the previous day. The police also said that he looked like a suicide bomber: he was trying to evade arrest and they suspected he was hiding explosives due to the big jacket he was wearing in the middle of summer. The Chair of the Metropolitan Police Authority subsequently stated that "Mr de Menezes was a wholly innocent victim caught up in the terrible events of 7 and 21 July."24

The widely criticised lethal shooting also brought to light that, unbeknown to both public and parliament, civilian police had been secretly trained to shoot to kill suspected suicide bombers. ${ }^{25}$ The shooting triggered public debate beyond the individual tragedy to broader issues of accountability: about whether or not "on-the-beat" civilian police has essentially shifted from a traditionally unarmed police to an armed force; and about what appropriate use of force within the context of counter-terrorism policing really amounts to. It also facilitated closer scrutiny of the police and demands for increased transparency. Importantly, police practices, the process of independent monitoring and review of policing in the UK continue to be publicly discussed as a result of this incident.

Yet in many Commonwealth countries, similar mistaken killings, more deliberate eliminations and the regulation of the use of force remains an unaddressed problem. Indeed the official 
tolerance of unaccounted for killings by law enforcement officers has a whole vocabulary for talking about actions, which if properly examined may turn out to be nothing less than murder and extra judicial killing. "Collateral damage", "disappearance", "encounter death", "crossfire" and "custodial death" are all terms whose widespread use covers up the truth about unlawful deaths along with the standards for use of lethal force.

In too many jurisdictions the use of lethal force is publicly condoned, privately lauded, and implicitly legitimated by the presence of permissive legislation, police immunity from prosecution and the failure to properly scrutinise police actions. In India and Pakistan, this has created so-called "encounter specialists" within the police. Often with dozens of kills to their credit, they are iconised in bollywood films, and the legality of their actions is too infrequently questioned or investigated.

\section{"Fake encounters"}

A fake encounter is the killing of a "suspect" by police during a staged gun battle. The victim may or may not be in police custody at the time. The police later claim that the victim was a suspected terrorist, a militant or a dangerous criminal.

In countries where court systems are chronically slow and police systems inefficient the generic extra-judicial killing of "terrorists" provides an easy way of eliminating suspects, political opponents, hardened criminals and others without the effort of going through the judicial niceties. Often these "terrorists" turn out to be children, dissidents, unarmed and peaceful protestors or disadvantaged civilians who are unlikely to have recourse to effective remedies.

As in some Caribbean and African nations, the number of extra-judicial deaths across South Asia is so alarming as to merit a full-scale review of the fundamentals of policing. But official attitudes sometimes preclude all efforts to reform. From its establishment in June 2004 to July 2006 there were a reported 283 crossfire killings attributed to Bangladesh's Rapid Action Battalion (RAB). ${ }^{26}$ No officer of the RAB has been charged over the deaths. ${ }^{27}$ Yet, rather than respond to accusations of too many crossfire killings, or to the concern that many crossfire victims are innocent, the thenState Minister for Home Affairs simply legitimated the climate of impunity surrounding the RAB when he announced at the RAB's one-year anniversary that "criminals cannot have any human rights." 28

In 2006 Haqbib Babu, an activist in the Bangladeshi Student League, was arrested and publicly shot in front of more than 100 witnesses. The RAB stated they had arrested Babu on information of his involvement in terrorist activity, and on arresting him had been involved in crossfire with other terrorists during which he was killed. His parents who are fighting for an investigation into their son's death have connections with the Bangladesh Awami League, an opposition party. Evidence of Babu's involvement has not been produced nor any to support the claim of a crossfire. None of the associates who allegedly executed the ambush have ever been caught, raising further doubt of the RAB's account. There has been no investigation into the incident and the accused continue to police the streets. $^{29}$

\section{Killed in the Crossfire}

In Bangladesh, death by crossfire describes the killing of a suspected criminal or terrorist by the Rapid Action Battalion (RAB) when allegedly attacked in an attempted ambush to facilitate the suspect's escape. Once arrested and officially in $\mathrm{RAB}$ custody, the suspect is supposedly killed in the midst of flying bullets.

Time and time again in Sri Lanka the decades long conflict between government and separatist militants allows suspect state actions to go unquestioned and unpunished. In January 2006 in the seaside town of Trincomalee the elite police Special Task Force allegedly beat up seven young Tamil students before firing at them killing five and seriously wounding two. ${ }^{30}$ Initially security forces claimed that the five were Tamil Tiger cadres readying an attack who were accidentally 
killed by their own grenade. ${ }^{31}$ The account soon emerged as a fake encounter. While several of the Special Task Force members have now been discharged from service, none have had to face criminal prosecution. The only witness to come forward is the father of one of the victims, who has since been directly threatened. As a result, the investigation has stalled and several of the officers involved remain on duty.

\section{Ensuring Counter-Terrorism is not Counter-Productive}

The defence is often made that enhanced police powers, reduced human rights safeguards and less police accountability are the only means to effectively counter terrorism. "Tough" policing often a term for tolerating policing by recourse to illegal means - is justified on these grounds. Indeed, across the Commonwealth, the atmosphere created by the "war on terror" has (with honourable exceptions) led to policing being remodelled into militaristic forces standing outside and in opposition to the community at large.

The argument for unreformed militaristic and tough policing only succeeds if terrorism actually diminishes; if the populations who were asked to suspend their civil liberties in the name of a greater danger are protected as a result; and if the erosion of human rights and the rule of law - the basis of faith in governments - leads to alternative

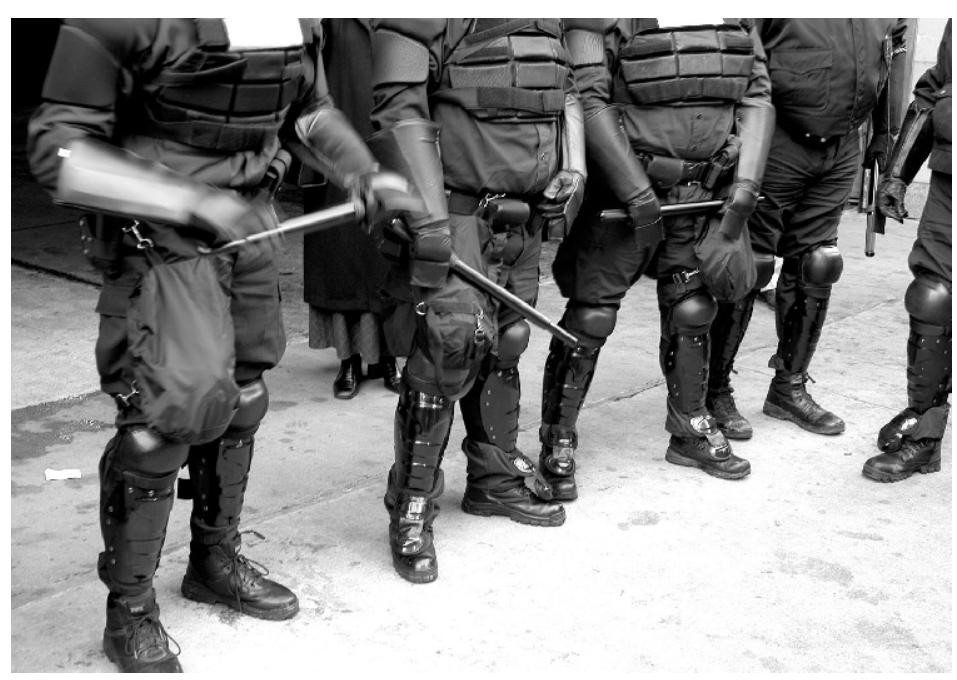
structures that are able to provide security for all. However experience indicates that rough, lawless policing and impunity have not been effective in curbing armed and violent opposition to the state and people now also have reason to be fearful of both terrorism and the police response to it.

In fact state tolerance for abusive policing may be one factor that encourages those sympathetic to terrorism. Minorities and unfairly targeted communities increasingly perceive themselves to be disproportionately stigmatised by police and at greater risk from their unbridled power. These sentiments breed opposition to the state and deepen susceptibility to the messages of terrorists who can then justifiably blame the state and promise retribution through violence.

Counter-terrorism has been demonstrably effective only when there are positive relationships between police and communities built on the knowledge that the police will be lawful, careful and fair. This has ensured the flow of information vital to preventing terrorist attacks and aided in the successful prosecution of offenders. The UK provides a valuable example: in 2006 UK police foiled a plot to blow up ten transatlantic flights thanks to intelligence from a member of the Muslim community. They also obtained enough evidence to bring charges against eight suspects. ${ }^{32}$ This successful operation relied heavily on police-public cooperation and public confidence in its functioning as an anti-terrorism force. However, attempts at reform by Commonwealth countries in ways that bring police and community together and reduce public alienation and minority grievance have been few and far between. Reform designed to counter terrorism requires that police be inclusive of the many hues of community: for instance through recruitment policies that ensure that community diversity is reflected throughout the police establishment. Police also need to have the confidence of the community, be welcome in it and be seen as being of service to it. 


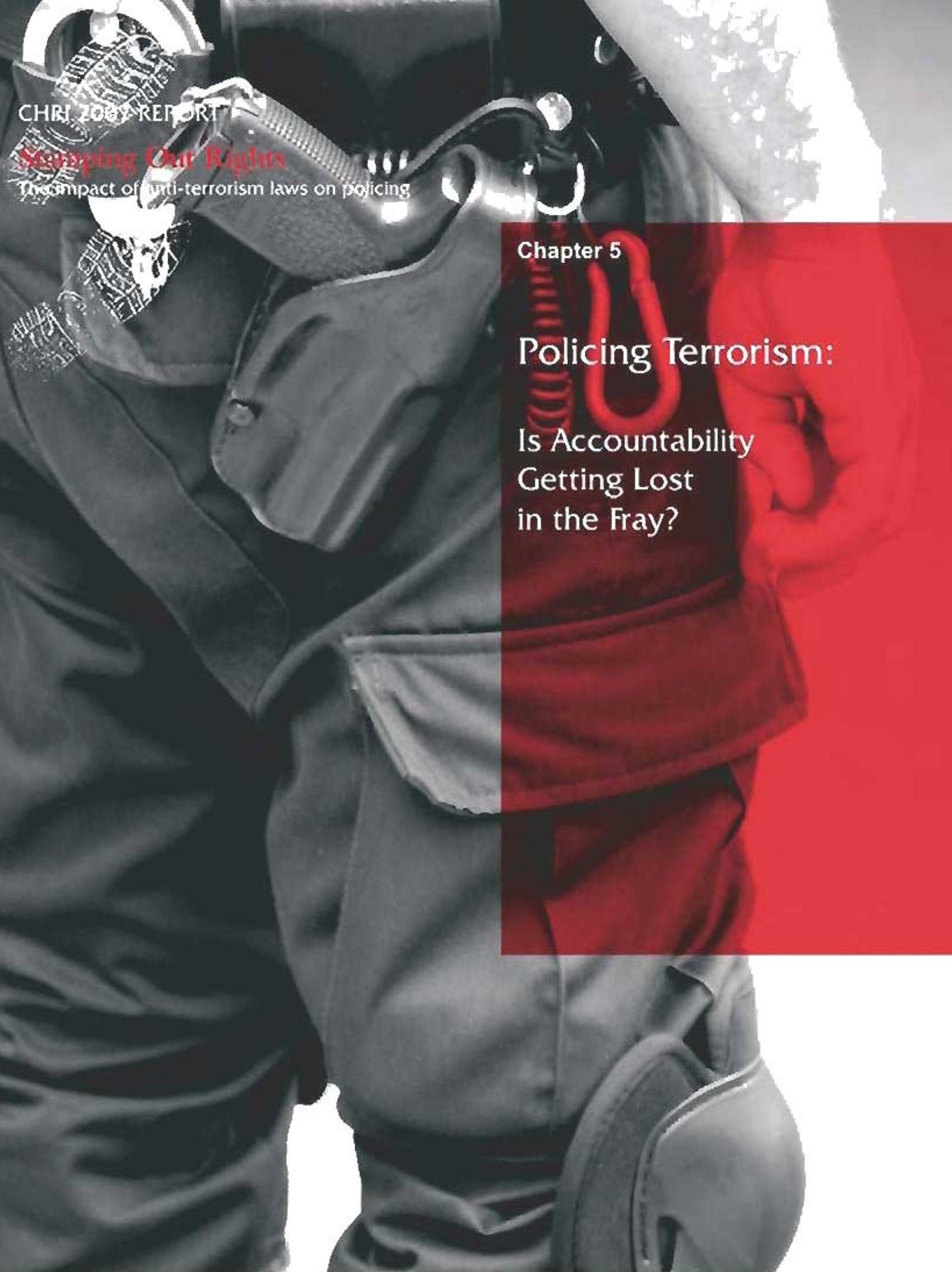




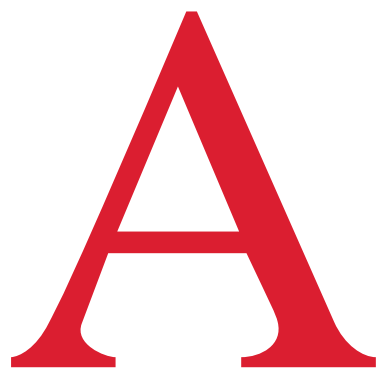

ccountability need not be held hostage to counter terrorism. The readiness to pass anti-terrorism legislation has not been coupled with the same zeal to ensure that broader police powers are accompanied by stricter accountability. Accounting for actions taken under cover of legal sanction, as well as for brazen misconduct, is no more rigorous: judicial review, internal disciplinary and monitoring procedures, and external oversight have not been correspondingly strengthened. There are a few notable examples where well-developed accountability mechanisms do what they can within their powers to maintain vigilant oversight of counterterrorism policing activities. But the reality in too many Commonwealth jurisdictions is that accountability over the police remains endemically weak.

\section{Accountability: Non-Negotiable in Any Circumstance}

Strict accountability over expanded powers should be non-negotiable because public trust in police propriety is a potent tool in the fight against terrorism. Stringent accountability is needed to instil public faith in the state's institutions and systems. Where populations are directly affected by conflict between police and terrorists, there is a particularly strong clamour for accountability. Sensing this popular mood, political parties contesting the 2002 elections in Jammu and Kashmir ran their campaigns on two promises: that all custodial killings and human rights violations by security forces would be investigated and that the state Human Rights Commission would be strengthened. ${ }^{1}$ Ongoing cycles of violence flourish because of a loss of faith in the state's policies, intentions and ability to protect the public. As a result people are hesitant to come forward with information in aid of the state, particularly when they feel that harm is as likely to come from the state as from non-state actors. Greater accountability can stop this cycle. Maher Arar, a Canadian citizen mistakenly imprisoned in Syria for alleged links to AlQaeda, champions the need for accountability after his experience: “... accountability is not about seeking revenge; it is about making our institutions better and a model for the rest of the world. Accountability goes to the heart of our democracy. It is a fundamental pillar that distinguishes our society from police states." ${ }^{2}$

- an independent judiciary;

- a responsible executive (through direct or indirect policy control over the police, financial control, and horizontal oversight by other government agencies such as AuditorsGeneral, Service Commissions and Treasuries); and

- at least one independent statutory body, such as an Ombudsman or Human Rights Commission or, ideally, a dedicated body, sitting outside the traditional arms of government, that deals with public complaints about the police.

Everyday policing needs careful monitoring to ensure that abuse is minimised and performance maximised. Importantly, people aggrieved by police conduct must have effective and accessible complaints forums. Though there are many and varied models, robust accountability requires vigilant internal procedures coupled with external oversight. Ideally, this involves the three arms of government plus at least one independent body.

Internal police accountability, with the formal disciplinary system at its centre, is the first line of defence against police misconduct. It is imperative that this system is transparent, pro-active and independent. In addition, police reform efforts in countries like South Africa and Northern Ireland point to the value of supplementing internal accountability systems with some form of external, non-police (preferably civilian) oversight. External accountability mechanisms, either as specialist police oversight agencies or autonomous government bodies such as human rights commissions, create avenues for public complaints to 
be pursued outside of the police. With one system complementing and reinforcing the other, and the constant oversight by the three arms of government, this approach creates a web of accountability in which it becomes increasingly difficult for police misconduct to take place without consequences.

Accountability needs to be extended in proportion to enhanced police powers. In order to achieve this, counter-terrorism policing requires accountability mechanisms to be vigilant over both specialised civilian policing units, and noncivilian security agencies such as military and intelligence services involved in anti-terrorism. This is particularly important in countries where there are newly created agencies or sub-units

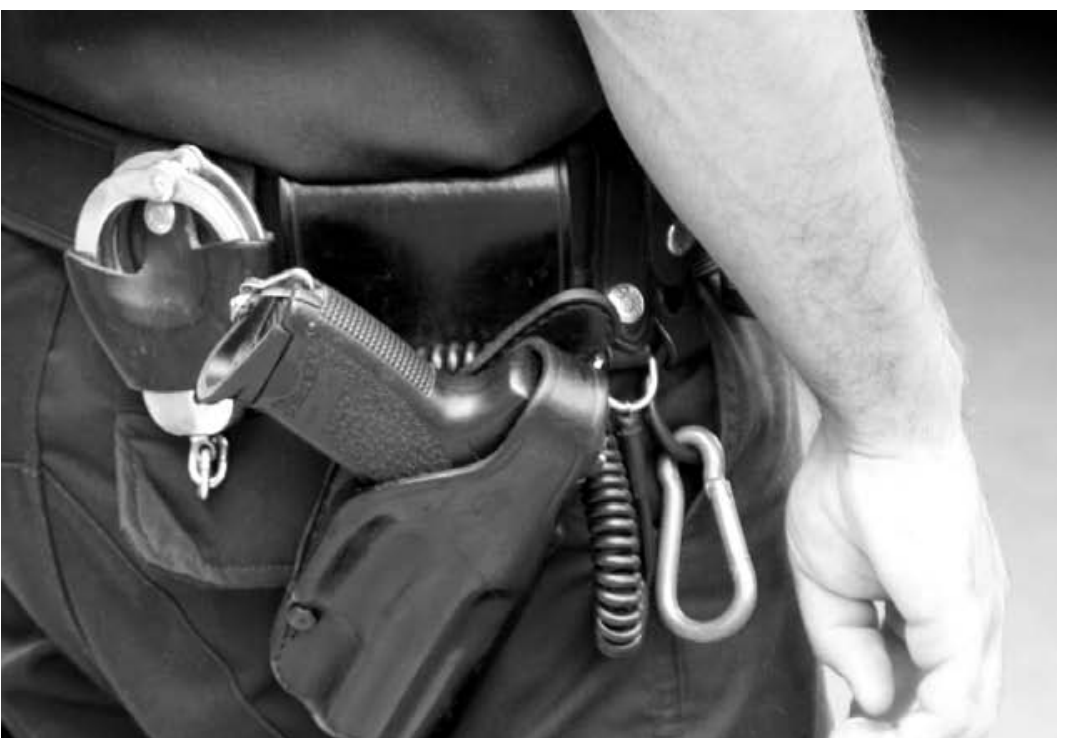
specially constituted to fight terrorism, often with no clear lines of accountability.

\section{The Worst-Case Scenario: Absent Accountability, Flourishing Abuses}

In counter-terrorism policing, grave human rights abuses by police and other security forces are a reality. Even where abuses are endemic and there is awareness within governments, deep-seated problems of violence and impunity persist. A first and necessary step to put a stop to these practices is a commitment to accountability. The state can quickly win back public goodwill by ending tolerance for human rights abuses by security forces. But often where this is most needed, the response is just not committed enough. Commenting on Sri Lanka, Human Rights Watch asserts, "perhaps more than anything else, impunity for human rights violations has helped to perpetuate the cycle of violence and reprisal that continues to plague the country." ${ }^{33}$ It does not help matters when abuses occur in remote, far-flung areas, further away from accountability's reach.

In two decades of civil war in Sri Lanka, more than 12,000 cases of "disappearances" have been reported to the UN Working Group on Enforced or Involuntary Disappearances; and virtually all of them have occurred in the midst of the violent conflict between the government and the LTTE. ${ }^{4}$ In most of these cases, there has been no information on the fate of the victims. Very few have been properly investigated and prosecuted. Human Rights Watch argues that "successive Sri Lankan governments have failed to prosecute those in the security forces responsible for serious human rights violations and war crimes". ${ }^{5}$ In the meantime, important oversight bodies in Sri Lanka such as the Human Rights Commission and the National Police Commission have been deliberately and severely undermined since early 2006, with the President's unilateral appointment of commissioners outside of the required constitutional process.

The Ugandan Lords Resistance Army, proscribed as a terrorist group in Uganda, intensified President Museveni's insistence on adopting a military approach to end the ongoing war in the north of the country. ${ }^{6}$ This led to the formation of the Joint Anti-Terrorist Task Force, a specialised unit that brings together military and police elements. The Uganda Human Rights Commission used army sources to confirm that undisclosed locations, referred to as "safe houses", exist and are used by units such as the task force to "contain suspected hard-core criminals involved in terrorism before they are taken to gazetted areas and later to the courts of law." Reportedly, safe houses emerged as a specific response of security forces to terrorist attacks. Extending checks 
and balances to these secret locations is challenging. For example, the Human Rights Commission was dependent on an army delegation for their investigation and was only able to establish the existence of these places, not who was detained there, for how long, and what happened to them.

Northern Ireland's Police Ombudsman has found evidence that Special Branch officers of the Royal Ulster Constabulary protected members of the banned Ulster Volunteer Force and allowed them to commit up to 15 murders over a period of 12 years towards the end of the conflict over British rule of Northern Ireland. ${ }^{8}$ Similarly, the recent fake encounter killings in Ganderbal district of Jammu and Kashmir call attention to the severe dangers of instituting a system of cash rewards and speedy promotions based on how many "terrorist" deaths a police officer is able to tally up.

\section{From Accountability to Impunity}

The journey to impunity is well traversed in many Commonwealth countries. It begins when police officers operate without respect for policing standards and are able to get away with it. Most if not all Commonwealth police organisations have mandatory internal procedures where officers are required to account for bullets used, and internal investigations into fatal shootings, deaths in custody, or instances where excessive force is used. In the context of counter-terrorism policing, it is vitally important to ensure the internal system is able to properly monitor the lawfulness of all arrests. In the absence of such mechanism, suspects are vulnerable to police abuse, which can spiral into enforced disappearances and extra-judicial killings. Yet, frequently, weak enforcement of these legal requirements in many countries has led in-built accountability procedures to fail.

Clauses providing police with de facto immunity from criminal proceedings are another attack on accountability. Immunity provisions often require state sanction, or evidence that the officer did not act in good faith before prosecution can take place. For instance, in Sri Lanka the sanction of the Attorney General is required for the prosecution of a police officer. ${ }^{9}$ In India, government sanction for prosecution of police is required, even on the basis of evidence collected by formal police investigation. ${ }^{10}$ Evidence from South Asia shows that when sought, state sanction is rarely forthcoming and thereby accountability is blocked. Similarly, Lesotho's Internal Security Act shields police officers for any actions committed in good faith under the Act. ${ }^{11}$ Uganda's AntiTerrorism Act allows for tremendously wide police powers of search and seizure, and also stipulates that investigation officers are not liable to any civil action in respect of anything done in good faith under the authority of an order issued under that section. ${ }^{12}$ Immunity provisions often render police accountability meaningless, in particular where they operate in the midst of welldocumented abuses.

\section{Active Accountability: Setting a Good Example}

There is cause for optimism where strong and independent police oversight bodies are in place. The Commonwealth is home to many examples of best practice in this regard. Created as integral parts of systemic police reform efforts, oversight agencies such as the Independent Police Complaints Commission of England and Wales, the Police Ombudsman of Northern Ireland, and the Independent Complaints Directorate of South Africa have all developed a reputation for truly independent investigation of public complaints. So much so that police leaders themselves speak in praise of the benefit of having such agencies. In South Africa for instance, the police have referred cases for investigation to the Independent Complaints Directorate. ${ }^{13}$ Human rights 
commissions also exert accountability, with wider mandates than police-specific oversight bodies, although many in the Commonwealth are constrained by limited resources, politicised appointments, and hostile environments.

In fact, numerous Commonwealth police oversight bodies are making efforts to extend their powers to include counter-terrorism policing. Perhaps due to its successful track record, the office of the Police Ombudsman of Northern Ireland has been called on to investigate deaths related to police action during the three decade conflict. ${ }^{14}$ Most significantly, the call to re-examine these cases has come from the Chief Constable, head of police in Northern Ireland. This is a strong signal of the importance to go back in time and hold the perpetrators to account for past as well as contemporary abuses. Reports speak of the field officers of the Sri Lanka Human Rights Commission who, in spite of grave constraints, do their utmost to provide some protection to victims of human rights violations by "proactively investigating cases and making use of all the investigation and protection powers conferred on them by the Human Rights Commission statute."15 In Australia, the mandate of the New South Wales Police Integrity Commission has included special oversight of counter-terrorism units within the New South Wales Police. For half a century, the Special Branch of the New South Wales Police was tasked with providing intelligence on terrorist activity. After a 1995 Royal Commission of Inquiry probed allegations of endemic corruption in the New South Wales Police, the Special Branch was disbanded in 1997. In turn, the Commissioner of Police, the New South Wales (NSW) government, and the Royal Commission each underlined the need for special oversight of the Protective Security Group that replaced the Special Branch. In response, NSW Police were required by law to conduct annual audits of the operations, policies and procedures of the Protective Security Group. Additionally, the Police Integrity Commission was mandated to conduct external reviews of police annual audits. ${ }^{16}$ In March 2003, the Protective Security Group's functions were absorbed into the newly created Counter Terrorist Coordination Command, but the legislative provisions were not amended to ensure the same scrutiny of the Command. ${ }^{17}$ A parliamentary inquiry commenced in February 2004 to address this glaring gap in legislation. In 2006, the Police Integrity Commission conducted a risk management assessment to examine the special oversight or monitoring arrangements needed to handle "the misconduct risks that result from the nature of the work undertaken by officers in the Counter Terrorist Coordination Command." ${ }^{, 18}$ 
Scrutiny of police counter-terrorism activities can polarise frontline police and their regulators. In 2001, the Police Ombudsman for Northern Ireland was criticised for her report into the Police Service of Northern Ireland's investigation of the Omagh bombing, "the single worst terrorist incident since the start of 'The Troubles' in 1969." ${ }^{22}$ The Ombudsman reported major failings of investigations by the Constabulary, and criticised the Chief Constable and Assistant Chief Constable for "defective leadership, poor judgment and a lack of urgency." ${ }^{, 23}$ The Police Service rejected these findings and the Chief Constable considered taking legal action to have the Ombudsman's report repealed..$^{24}$ Moving forward to 2007, another investigation report of the Ombudsman found evidence of police collusion with paramilitary informants near the end of "the Troubles." This time, perhaps as a result of years of credibility accumulated by the Ombudsman, the Police Service has accepted all of the recommendations. This is an indication that even in the context of terrorism, once police oversight bodies demonstrate they can use their powers effectively and will not be intimidated, their recommendations will be readily taken on board.

\section{The Challenges of Making Oversight Effective}

Whether specific to the police or with wider mandates, oversight bodies must be adequately empowered not just to highlight human rights abuses, but also to investigate abuses and assist in the prosecution of those responsible. Nigeria's Police Service Commission provides a good example of oversight powers. The Commission can investigate complaints against police officers, enforce any disciplinary measures it deems appropriate, and refer cases for criminal prosecution. Notably, it also has the power to frame and implement policy for the police. This could include guidelines to carry out counter-terrorism policing while respecting human rights. Unfortunately, in many Commonwealth countries oversight bodies are kept weak and unable to exercise their functions to full potential. Nigeria's Police Service Commission is a case in point where due to "the lack of resources, the delegation of some of its powers to the police, the absence of an adequate legal framework, and the interference of politicians" the Commission has not been able to flourish. ${ }^{25}$ In another example, the human rights unit of Papua New Guinea's Ombudsman Commission had only one staff member in $2006 .{ }^{26}$ This is clearly insufficient given the absence of a national human rights commission in the country. In fact, such severe under-resourcing can make oversight powers redundant. For instance, the Police Complaints Authority in New Zealand and the National Police Commission in Sri Lanka delegate all cases of complaints investigation back to the police. While both bodies have extensive investigative powers they lack the capacity to put them into practice.

Serious legal lacunae present another hindrance to effective oversight. Malaysia's Human Rights Commission Act 1999 is often cited for shortfalls that prevent it from conforming to the Paris Principles, which lay down the minimum standards for the establishment of effective national human rights institutions. In India, shortcomings both in law and practice translate directly into lessened accountability over counter-terrorism policing. The Protection of Human Rights Act 1993 does not allow state human rights commissions to investigate human rights violations by members of the armed forces. ${ }^{27}$ India's National Human Rights Commission has a slightly wider ambit in this regard - it can seek a report from the central government into the alleged abuses by armed forces personnel, but it cannot inquire on its own before making its recommendations. ${ }^{28}$ Shadowy joint counter-terrorism police and military operations often fall off the radar precisely because independent accountability mechanisms cannot exercise their powers over them, and weak criminal justice systems make it practically impossible for individuals to file complaints against police officers suspected of abuse.

Following the strong precedent set by the Police Ombudsman for Northern Ireland, with the 
proper powers and resources, oversight bodies can unearth abuses under counter-terrorism policing, gather concrete evidence, and pinpoint accountability. In addition, oversight bodies can also review legislation to check for compliance with human rights standards, monitor police investigations of public complaints, visit places of detention, and in some jurisdictions, identify and review systemic problems within police organisations. It is immensely important that oversight bodies exercise their powers to the fullest extent, particularly with a view to exposing abuses and calling for prosecution of implicated officials. Examples from around the Commonwealth reveal that oversight bodies are better at highlighting abuses or ordering compensation, but less assertive in propelling prosecutions - a gap that must be bridged urgently.

The Human Rights Commission of Malaysia has been at the forefront in calling for repeal or reform of the Internal Security Act (ISA) to better protect human rights, and has also exercised its powers to monitor the treatment and detention conditions of ISA detainees. Yet in March 2006, Amnesty International expressed serious concern that reports of torture or ill treatment of ISA detainees by police had not been effectively investigated. ${ }^{29}$ The Uganda Human Rights Commission, which has significant judicial powers, has pointed out that torture continues to be a widespread practice within security organisations. In 2003 the Commission cited the police and the army as the principal perpetrators of torture, and reiterated this in $2005 .^{30}$

\section{Sri Lanka's Crippled Accountability System}

Many of Sri Lanka's key accountability mechanisms have been crippled by abuses of executive prerogative. In October 2001 Sri Lanka's Constitution was amended, strengthening the process of appointment to key existing oversight bodies such as the Human Rights Commission and the Bribery Commission. Importantly it created two new rights monitoring bodies: the National Police Commission and the Elections Commission. The newly established Constitutional Council made recommendations to the President for appointment of members to the new Commissions. The National Police Commission has a twofold mandate: to administer appointments, promotion, transfer, and disciplinary control of all police officers except the head of police (the Inspector General of Police); and to establish procedures to investigate public complaints against the police. Intended to bring in a measure of accountability and release the police from illegitimate political interference, the Commisson "may well have proved to be a shining example for the rest of South Asia." However appointments to the second Constitutional Council were not made as scheduled because political interests delayed agreement to one member. Without the Council in place, President Mahinda Rajapakse has unilaterally made his own appointments to the National Police Commission, including many of his supporters and personal friends. ${ }^{33}$ The Commission is currently not operating in accordance with its constitutionally enshrined process.

In India, the National Human Rights Commission awarded monetary compensation in October 2006 in a case originating from the years of terrorism in the state of Punjab, involving enforced mass disappearances of suspected militants. The Commission awarded the compensation based on a report by India's Central Bureau of Investigation that found the Punjab Police had illegally cremated 2097 bodies at three sites in the Amritsar district alone. Yet, the Commission stopped short of investigating individual cases or recommending the prosecution of officers. It refused to "go into the systemic patterns of violations and declined to investigate the issues of rights to life and liberty." ${ }^{31}$ This case demonstrates that even independent oversight is sometimes not enough to hold police to account in the absence of a steadfast commitment to human rights of oversight bodies themselves. 


\section{Accountability from Other Quarters}

A sign of strong accountability is when checks and balances come from multiple sources. Courts can play an important role in reviewing and overturning policies that impede civil liberties. In 2006, the United Kingdom Court of Appeal assessed whether the effect of six control orders violated the right to liberty and security contained in Article 5 of the European Convention on Human Rights. ${ }^{34}$ The Court found that the control orders implemented unnecessary restrictions amounting to a deprivation of liberty and it quashed the orders. While this was a significant check on executive authority, the political will required to see this reform through was missing. In practice, the only change was to reduce the maximum period of time a person's movement could be restricted from 18 hours to 14 hours. This failed to address the underlying concern of the Court that control orders could result in the illegitimate deprivation of liberty.

True accountability requires a judiciary that is independent and pro-active. In Kenya, the Court of Appeal has the capacity to monitor the application of the law and identify bad practice. Additionally Kenya's Police Manual requires that if a judge criticises the conduct or evidence of a police officer, they must immediately submit a report to their superior. Unfortunately there are long-standing concerns about the lack of independence of Kenya's judiciary, particularly in the lower courts, compounded by a history of susceptibility to corruption and bribery. ${ }^{35}$ Moreover there is no evidence that such judicial oversight takes place. This is particularly concerning given Kenya's Anti-Terrorism Unit's targeting of minorities.

In the UK, legislative scrutiny bears directly on the implementation of anti-terrorism law through the establishment of an independent reviewer. The independent reviewer is a member of the House of Lords but not from either of the two major political parties in Parliament. His brief is to ensure terrorism laws "strike a delicate balance between providing effective tools to investigate while ensuring our civil liberties are not unnecessarily infringed. ${ }^{, 36}$ He overviews the making and operation of every control order put into force and presents his report to the Home Secretary. Importantly, he also reports to the public. ${ }^{37} \mathrm{He}$ is assured access to the same material as the Home Secretary, including confidential police reports, intelligence files and evidence. This privileged access lends weight to his assessments in Parliament. ${ }^{38}$ The role of an independent reviewer ensures the necessity and justification for anti-terrorism measures can be strongly informed by international human rights obligations, irrespective of political agenda.

Members of Parliament (MPs) - or of State Legislatures or Local Councils - have many routine opportunities for police oversight through question time, annual departmental reviews, and examination of public interest issues in the parliamentary committee system. Attempts by governments to impose draconian anti-terrorism laws were blocked by the well-informed objections and concerns of MPs in Australia and the United Kingdom, demonstrating how legislatures can defend key democratic liberties even when pitted against "national security" concerns. Legislatures are the final forum for substantive debate on new anti-terrorism or security legislation, and the onus is on them to bear this responsibility through serious consideration.

In some cases working under severe threat, civil society organisations and individual activists across the Commonwealth are active in policy level debates and intervention, as well as unearthing and documenting human rights abuses on the ground by security forces. Liberty, a prominent London-based civil liberties group, is consistently active in publishing policy papers in response to new Home Office policies on terrorism, and submitting evidence before parliamentary committees. Liberty is a strong civil society voice that continues to challenge 
government moves to increase pre-charge detention periods, particularly by arguing for stronger investigative powers for the police. ${ }^{39}$ In Canada, civil society groups were integral in calling for a public inquiry into Maher Arar's case and also acted as interveners in the inquiry itself. Answering the inquiry commission's call for submissions on policy review in December 2004, the International Civil Liberties Monitoring Group (a coalition of Canadian NGOs) provided a comprehensive submission on the need for an external accountability body to review the national security activities of the Royal Canadian Mounted Police.

Legal activism by civil society groups can lead to intervention of the courts to curb excesses by security forces. In June 2007, the Centre for Policy Alternatives (a Colombo-based nongovernmental organisation) submitted a fundamental rights application to the Supreme Court of Sri Lanka, in response to the mass eviction of Tamils from Colombo on 7 June 2007. Citing security concerns, police and army officers had forcibly removed hundreds of Tamils from guesthouses in the capital. They were taken away in buses to the war affected provinces in the north and east of the country. After the application was filed, the Supreme Court issued an order putting a halt to the evictions and preventing any more. ${ }^{40}$ The Prime Minister of Sri Lanka publicly apologised and took full responsibility for the mass removals on behalf of the government. ${ }^{41}$

The occasional investigations and reports of commissions of inquiry (often judicial commissions in the Commonwealth context) can be path breaking. In New South Wales (Australia) the 1997 Wood Royal Commission led to greater oversight requirements specific to counter-terrorism policing units being written into law. More recently, in Canada, the release of the findings of a Commission of Inquiry has underscored the urgent need for external review of the intelligence activities of the Royal Canadian Mounted Police and other security agencies. The public inquiry was created to examine the case of Maher Arar. Bowing to public outcry following Arar's return to Canada in October 2003, the Canadian government announced the Commission of Inquiry into the Actions of Canadian Officials in Relation to Maher Arar. The Commission released its findings in two reports in 2006. The Commissioner found that the Mounted Police's sharing of false and misleading information that suggested Arar was linked to al-Qaida was "very likely" a factor in leading to the decision by American authorities to deport him. When the Commission publicly cleared Maher Arar of all terrorism allegations and criticised the Mounted Police's failings in the case, its Commissioner Giuliano Zaccardelli resigned, after admitting he misled Parliament in Arar's case. He also publicly apologised and said his force had made major mistakes. ${ }^{42}$ Arar's lawyers are seeking disciplinary action against other Mounted Police's officers involved in the case.

Independent investigations are necessary to disclose the true scale of disappearances and extrajudicial killings done at the hands of security personnel. Getting to the heart of specific cases leads to individual prosecution and can bring about systemic change. It is also fundamentally counter-productive to leave long-term conflicts unresolved. While she was heavily criticised by the Royal Ulster Constabulary leadership for her findings, the Police Ombudsman of Northern Ireland's investigation into the Omagh bombing brought significant changes to Northern Ireland police's investigative structures and processes. This included a full review of the role and function of the Special Branch, as well as a renewed investigation into the bombing itself. ${ }^{43}$ That is the power of credible, evidence-based, detailed oversight.

The Canadian Commissioner, Dennis O'Connor, concluded in the Maher Arar case that "increased information sharing, increased police powers of coercion and increased integration among Canadian and foreign national security actors" necessitates a new review agency to oversee the Royal Canadian Mounted Police's national security activities, as well as a new review 
process for five other federal departments and agencies involved in national security. ${ }^{44}$ The Commissioner recommends the establishment of the Independent Complaints and National Security Review Agency for the Mounted Police, with the jurisdiction to review all of its activities including those related to national security. In terms of the Mounted Police's national security activities, the Commissioner recommends that the Agency be given the authority to conduct self-initiated reviews of its "compliance with laws, policies, international obligations and for standards of propriety expected in Canadian society." ${ }^{, 5}$ In fact, Commissioner O' Connor is simply applying the principle of external independent oversight to counter-terrorism policing.

\section{What Accountability is Needed?}

There are clear steps that must be taken to ensure accountability in counter-terrorism policing. These include defining the role of police, particularly in relation to other agents such as military or paramilitary forces. The role of police must be regularly evaluated and activities audited to monitor and hold to account any examples of wrongdoing. Police must strictly adhere to internal reporting and investigation procedures in counter-terrorism and all other areas of policing. Additionally and where possible, special oversight mechanisms should be considered in antiterrorism legislation that grants specific powers to police. Finally, and as always, no measure is successful if it exists on paper only. Police accountability requires resources, and practical and political support to ensure it provides efficient and effective oversight.

The Commonwealth faces a great challenge to promote truly independent and vigilant police oversight in the face of mechanisms that are weak, lack independence, have been poorly implemented or are non-existent. Commonwealth members must use the best practices available in their accountability measures, and extend them to specific areas including counter-terrorism policing. Additionally, the Commonwealth should support initiatives like the International Network for the Independent Oversight of Policing in the development and implementation of internationally agreed standards on police oversight. Only through active leadership can the Commonwealth ensure that bad practice and poor accountability do not prevail. 
CHR 20 E RERORT

Stamping Out Rights

Thas mpacs of anti-terrorism laws on policing
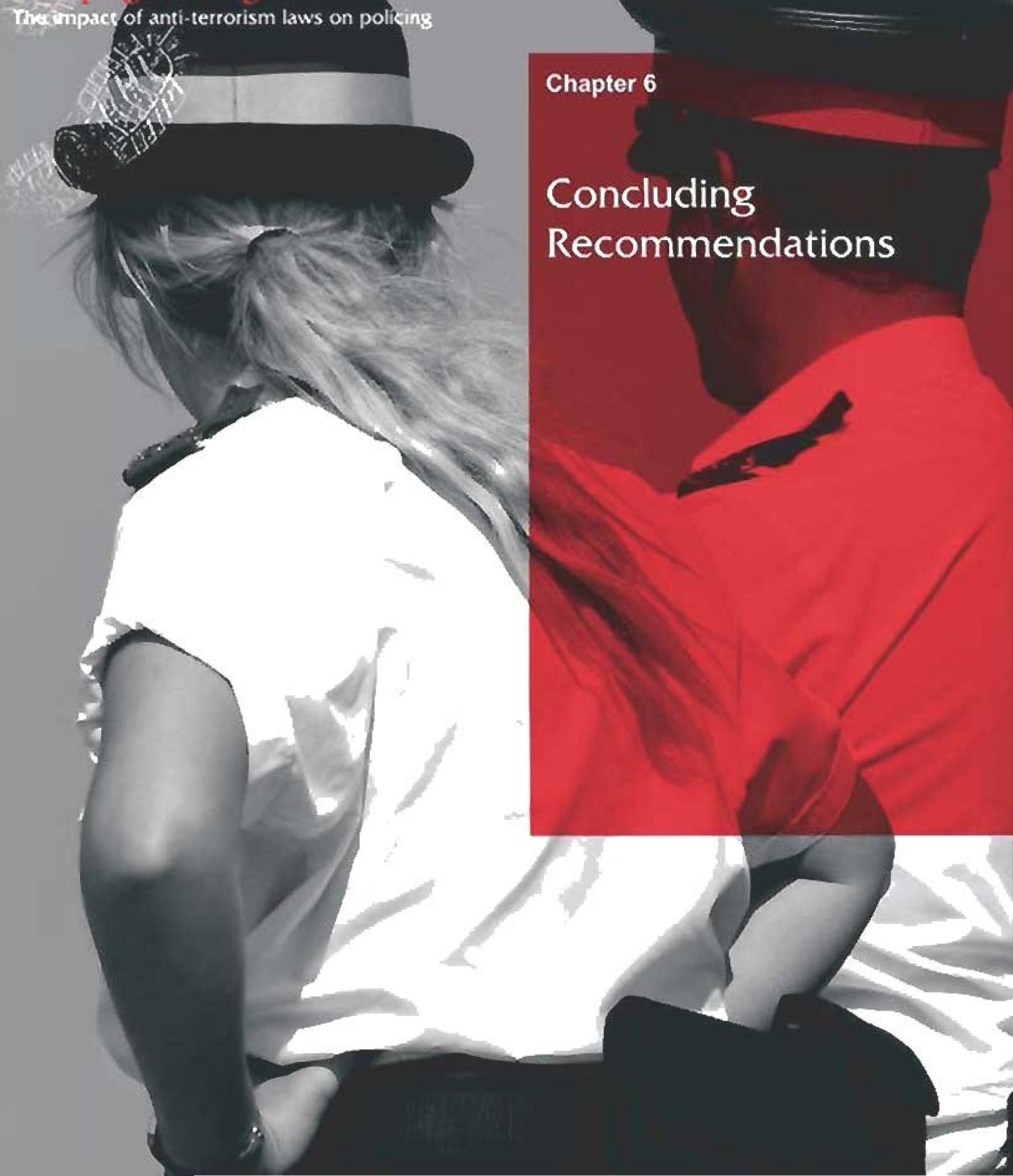


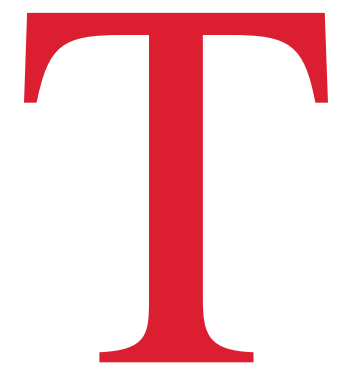

he primary objectives of policing are to ensure the safety of the state and its people through the maintenance of law and order, and to protect rights and freedoms as the institutions of democracy itself. Only through achieving these objectives can we ensure true security. Unfortunately, the contemporary agenda of anti-terrorism has mistakenly presented human rights as a hindrance to effective counter-terrorism policing and has prioritised a harsh response over long-standing principles and fundamental freedoms. Individuals and the state have become more vulnerable under anti-terrorism measures whose latitude in application has demonstrably undermined the rule of law, reduced the protections of due process and diluted international human rights standards. Not only do these responses ignore the international obligations of all Commonwealth states, they are counter-productive to effective and successful counter-terrorism.

Police violations of human rights are not just a matter of record. They cause real harm to real people. Abusive police practices have the potential to isolate the very populations who most need the protection of the police. Lack of community support also undermines operational policing and amplifies the difficulties for police in responding to terrorism. In too many Commonwealth countries, where existing accountability structures are weak or poorly implemented, it is easier for police to deviate from existing norms and standards with impunity. Elsewhere, accountability mechanisms are failing to keep up with increased police powers, enhanced discretion and reduced protections of due process. As a result some policing practices rival the effects of terrorism itself as they spread fear through communities and undermine the state's ability to protect its people. Legislative and police reform throughout the Commonwealth are of the utmost urgency to ensure effective law that sets clear parameters for the use and accountability of police powers and upholds the fundamental principles of the rule of law and human rights.

\section{The Commonwealth}

The Harare Commonwealth Declaration (2001) established democracy and good governance, human rights and the rule of law, gender and racial equality and sustainable economic and social development as the fundamental political values of the Commonwealth.

\section{Commonwealth Heads of Government must:}

- review member states' measures to counter terrorism at the Commonwealth Ministerial Action Group and take action against those members who fail to uphold the fundamental political values of the Commonwealth in their responses to terrorism;

- mandate the Commonwealth Secretariat to ensure that the provisions in the Commonwealth's Model Legislative Provisions on Measures to Combat Terrorism are amended to promote human rights standards and to include guidelines for human rights training for police forces;

- mandate the Commonwealth Secretariat to establish a police expert group to guide and assist police practices and operations, including counter-terrorism policing throughout the Commonwealth;

- mandate the Commonwealth Secretariat to bring Heads of Police together annually to share lessons and strategies for democratic policing;

- mandate the Commonwealth Secretariat to encourage member states to engage in a dialogue to adopt a common position on anti-terrorism laws at the international level including at the United Nations;

- mandate the Commonwealth Secretariat to provide assistance and regular monitoring to ensure that states take full account of, and act in accordance with, the recommendations and observations of the United Nations Human Rights Council and Special Rapporteurs on matters pertaining to human rights compliance when countering terrorism;

- actively support renewal of the mandate of the United Nations Special Rapporteur on the Promotion and Protection of Human Rights and Fundamental Freedoms while Countering Terrorism (due to expire in 2008); 
- actively support continued and increased cooperation between the United Nations CounterTerrorism Committee and the Special Rapporteur on the Promotion and Protection of Human Rights and Fundamental Freedoms while Countering Terrorism; and

- actively support the consideration by the United Nations Counter-Terrorism Committee of human rights and rule of law compliance as an essential element of the examination of all state reports to the Committee, and country visits by the Committee's Executive Directorate.

\section{Commonwealth Member States}

Bound by the Harare Commonwealth Declaration as well as other international, regional and national human rights obligations, member states must implement their obligations through national law as required under the charter of the United Nations. This requires that anti-terrorism legislation must comply in all cases with human rights and the rule of law.

\section{Member states must:}

- ratify core human rights instruments and ensure their implementation in domestic law;

- urgently undertake police reform and review all agencies involved in state law enforcement, including counter-terrorism, to ensure compliance with the standards of democratic policing in accordance with human rights principles and the rule of law;

- establish a clear definition of terrorism before taking any further steps towards legislation, restricting that definition to the cumulative characteristics identified in Security Council Resolution 1566 (2004) and going no further;

- undertake pre-legislative scrutiny of proposed anti-terrorism laws to ensure compliance with accepted human rights and civil liberties norms and provide for public consultation;

- ensure that in all but the most extreme cases civilian police are the only agents empowered to carry out policing tasks;

- establish and implement appropriate, robust, independent police oversight bodies and ensure that they are applicable to special and combined units as well as traditional civilian policing;

- actively investigate alleged abuses of police powers by cooperating with national human rights institutions and other independent oversight bodies; and

- support international networks for democratic policing and accountability through structures including the International Network for the Independent Oversight of Policing.

\section{Commonwealth Heads of Police}

The rule of law, human rights and democracy are core values of policing throughout the Commonwealth and must be integrated into its vision, policies and procedures everywhere in the Commonwealth.

\section{Heads of Police must:}

- ensure maximum transparency to build public confidence in the police and strong police-community relationships;

- establish recruitment policies that ensure population diversity is reflected within the police and that the police service has cross cultural competency and diverse language skills;

- take particular care to ensure that policing is demonstrably nondiscriminatory and that bias is neither tolerated within the service nor in law enforcement;

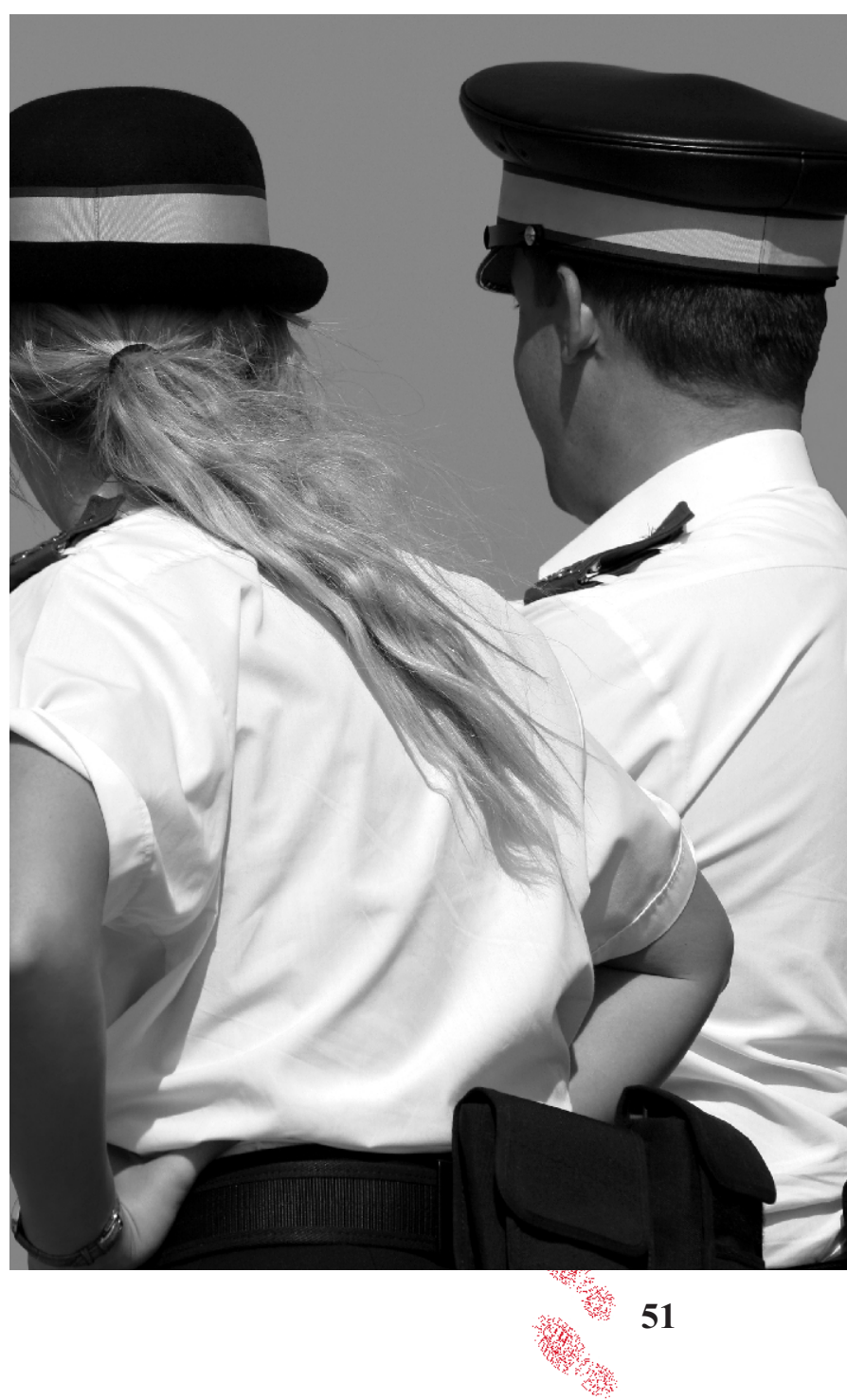


- provide active leadership to ensure internal police policy establishes conduct and procedures in accordance with democratic policing, human rights and the rule of law;

- increase internal reporting, investigation and prosecution processes to address all cases of extra-judicial killings, disappearances and other human rights abuses by the police;

- ensure that all law enforcement whether done alone or in combination with special forces is subjected to the highest standards of oversight and sanctions;

- ensure that whistleblowers, victims and witnesses are well protected and not subject to harassment or threat by police officers and that such practices receive strict disciplinary action; and

- hold annual meetings to share lessons on democratic policing.

\section{Civil Society must:}

- demand and publicly disseminate information about anti-terrorism laws and policing to create a democratic discourse, and participate actively in public debates on policy and legislation;

- campaign for reform and accountability of all policing including counter-terrorism;

- review and assess police functioning in accordance with national and international standards and continuously challenge and draw attention to police wrongdoing; and

- engage in partnerships with the police to bring about greater community involvement and improve community safety.

\section{Donors must:}

- require that human rights be integrated into all donor-supported counter-terrorism programs;

- take firm measures against recipients, including states, who curb civil liberties and fail to adhere to international human rights standards in the context of counter-terrorism and general policing; and

- prioritise funding civil society organisations which promote or support human rights. 


\section{APPENDIX I}

\section{Methodology}

This report is an advocacy document. It sets out the nature of current anti-terrorism legislation relating to police powers, and how that framework has impacted upon human rights and the rule of law. It does not seek to present academic analysis, policy proposals or a model for legislative reform.

This report was written by a team of staff and interns at CHRI's head office in Delhi, and builds on research undertaken by CHRI on counter-terrorism, policing and human rights since 2003.

Initial data was compiled in individual country reports written by CHRI on all 53 Commonwealth countries. These reports followed a template format addressing the existence of anti-terrorism legislation and examples of how this legislation affected policing practice. Research focused on the following areas:

- existence and nature of specific anti-terrorism legislation in the country;

- when the legislation had been introduced, specifically prior to or since 2001;

- existence and nature of definitions of terrorism, terrorist and terrorist act;

- nature of offences proscribed under the legislation;

- impact upon police powers, particularly in relation to arrest, detention, investigation and charge;

- immunity provisions or other measures effecting accountability; and

- any history of terrorism in or affecting the country.

\section{CHRI's country reports on anti-terrorism laws and policing are available at: www.humanrightsinitiative.org.}

From these data, case studies drawn were used to develop the analysis of how anti-terrorism legislation has affected police practice throughout the Commonwealth, in individual countries, regionally and internationally. State obligations to human rights and the rule of law were the basis from which this effect was measured.

Research was desk-based, relying primarily on internet sources including government and non-government reports, journals, media, policy documents and other publications. Contacts in government, academia and civil society supplemented information and referred us to additional experts in the areas of anti-terrorism legislation, human rights, policing and security.

The report went through internal editorial review, and national and international experts reviewed both the country reports and the final report for accuracy of detail and analysis. Whilst the feedback from these reviews was incorporated into the final report, CHRI takes full responsibility for any errors. 


\section{APPENDIX II}

\section{International standards referred to in this Report}

This annexure provides details on the international Conventions that are of greatest relevance to this report.

United Nations Charter, 1945

This Charter establishes the United Nation, based on the principles of peace and security, and the promotion of human rights and fundamental freedoms.

Universal Declaration of Human Rights, 1948

The UDHR is a fundamental source for legislative and judicial practice throughout the world, and a basis for all other international treaties and conventions. The UDHR defines the duty of governments to protect human rights, and lays down principles or standards for all states to follow.

Convention Relating to the Status of Refugees, 1951

The Convention defines the status of refugees and their consequent rights. It prevents states from expelling refugees or sending them to a country where they may face persecution ("non-refoulement").

International Convention on the Elimination of All Forms of Racial Discrimination, 1965

ICERD reaffirms that all human beings are born free and equal in dignity, and should be entitled to equal protection of the law against any discrimination. Signatory states take responsibility for prohibiting and eliminating racial discrimination in all its forms. The UN Committee on the Elimination of Racial Discrimination was established under this Convention to monitor how states fulfill these responsibilities. The Committee also accepts complaints from one state about racial discrimination by another state.

International Covenant on Civil and Political Rights, 1966

ICCPR widens the range of rights established by the UDHR and establishes the UN Human Rights Committee to monitor implementation.

International Covenant on Economic, Social and Cultural Rights, 1966

Introduced together with the ICCPR, this Covenant develops further the rights contained in the UDHR. The Committee on Economic, Social and Cultural Rights monitors its implementation.

Optional Protocol to the International Covenant on Civil and Political Rights, 1966

This optional protocol establishes systems for the Human Rights Committee to receive and consider communications from individuals who claim to be victims of human rights violations by any signatory states.

Convention against Torture and Other Cruel, Inhuman or Degrading Treatment or Punishment, 1984

CAT prohibits the use of torture or any other inhuman or degrading treatment in attempting to obtain information from a suspect. It is one of the most important declarations to be observed by police officials in the exercise of their duty. The CAT establishes the Committee against Torture, which can consider individual complaints and complaints about torture from one state about another.

Convention on the Rights of the Child, 1989

$\mathrm{CRC}$ recognises the rights of children, including child suspects, and requires that every child alleged to have infringed the penal law should be treated in a manner consistent with the promotion of the child's sense of dignity and worth. A Committee on the Rights of the Child was established, but it does not take individual cases.

Standard Minimum Rules for the Treatment of Prisoners, 1955

Adopted by the First UN Congress on the Prevention of Crime and the Treatment of Offenders, and approved by the Economic and Social Council in 1957, these rules set out principles and good practice in the treatment of prisoners and the management of 
institutions. The Rules were among the first international instruments for the protection of the rights of those accused of committing a criminal offence.

UN Code of Conduct for Law Enforcement Officials, 1979

This code sets out basic standards for police agencies across the world. It requires police officials in signatory states to recognise the rights set out in the UDHR and other international conventions.

Declaration of Basic Principles of Justice for Victims of Crime and Abuse of Power, 1985

This Declaration defines victims and their rights, and aims to ensure that police, justice, health, social services and other personnel dealing with victims are able to provide proper and prompt aid.

UN Standard Minimum Rules for the Administration of Juvenile Justice ("The Beijing Rules"), 1985

The Rules are intended to be universally applicable across different legal systems, setting minimum standards to be observed in the handling of juvenile offenders. These rules require that law enforcement agencies respect the legal status of juveniles, promote their well-being, and avoid any harm to young suspects or offenders.

Body of Principles for the Protection of All Persons under Any Form of Detention or Imprisonment, 1988

The Body of Principles reaffirms that no person detained shall be subjected to torture or to cruel, inhuman or degrading treatment or punishment, or to any form of violence or threat.

Principles on the Effective Prevention and Investigation of Extra-Legal, Arbitrary and Summary Executions, 1989

These principles concern the arbitrary deprivation of life, and establish measures to be taken by governments to prevent, investigate and take legal proceedings in relation to extra-legal, arbitrary and summary execution. The Principles should be taken into account and respected by governments within the framework of their national legislation and practice.

Basic Principles on the Use of Force and Firearms by Law Enforcement Officials, 1990

Adopted during the 8th UN Congress on the Prevention of Crime and the Treatment of Offenders, these principles set up a series of human rights standards regarding the use of force and firearms by law enforcement officials. They function as the global standards for police agencies worldwide, although they are not enforceable in law.

UN Standard Minimum Rules for Non-Custodial Measures ("The Tokyo Rules"), 1990

The Tokyo Rules are basic principles to promote the use of non-custodial measures in punishment, as well as minimum safeguards for persons subject to alternatives to imprisonment.

UN Rules for the Protection of Juveniles Deprived of their Liberty, 1990

These rules are intended to establish minimum standards for the protection of juveniles deprived of their liberty in all forms, consistent with human rights and fundamental freedoms, and with a view to counteracting the detrimental effects of all types of detention and to fostering integration in society.

Declaration on the Protection of All Persons from Enforced Disappearance, 1992

This body of principles arose from deep concern in the UN about persistent reports of enforced disappearance caused by state officials, including police.

Principles Relating to the Status and Functioning of National Institutions for Protection and Promotion of Human Rights ("Paris Principles"), 1993

Set of internationally recognised standards created to guide states in the setting up of effective human rights commissions.

Declaration on the Right and Responsibility of Individuals, Groups and Organs of Society to Promote and Protect Universally Recognised Human Rights and Fundamental Freedoms, 1998

This Declaration sets down principles to ensure that states support the efforts of human rights defenders and ensure that they are free to conduct their legitimate activities without fear of reprisals. 


\section{APPENDIX III}

\section{Ratification of human rights instruments by Commonwealth countries}

\begin{tabular}{|c|c|c|c|c|c|c|c|c|c|c|c|c|c|}
\hline COUNTRY & CPR & $\begin{array}{c}\text { OP I } \\
\text { ICCPR }\end{array}$ & $\begin{array}{c}\text { OP II } \\
\text { ICCPR }\end{array}$ & $\begin{array}{l}\text { ICE } \\
\text { SCR }\end{array}$ & ICERD & ICRMW & CEDAW & $\begin{array}{c}\text { OP } \\
\text { CEDAW }\end{array}$ & CAT & $\begin{array}{c}\text { OP } \\
\text { CAT }\end{array}$ & CRC & $\begin{array}{c}\text { OP } \\
\text { CRC } \\
\text { AC }\end{array}$ & $\begin{array}{c}\text { OP } \\
\text { CRC } \\
\text { SC }\end{array}$ \\
\hline Antigua and Barbuda & $\mathrm{x}$ & $\mathrm{x}$ & $\mathrm{x}$ & $\mathrm{x}$ & $\mathrm{R}$ & $\mathrm{x}$ & $\mathrm{R}$ & $\mathrm{R}$ & $\mathrm{R}$ & $\mathrm{x}$ & $\mathrm{R}$ & $\mathrm{x}$ & $\mathrm{R}$ \\
\hline Australia & $\mathrm{R}$ & $\mathrm{R}$ & $\mathrm{R}$ & $\mathrm{R}$ & $\mathrm{R}$ & $\mathrm{x}$ & $\mathrm{R} \circledast$ & $\mathrm{x}$ & $\mathrm{R}$ & $\mathrm{x}$ & $\mathrm{R}$ & $\mathrm{R}$ & $\mathrm{R}$ \\
\hline Bahamas & $\mathrm{x}$ & $\mathrm{x}$ & $\mathrm{x}$ & $\mathrm{x}$ & $\mathrm{R}$ & $\mathrm{x}$ & $\mathrm{R} \circledast$ & $\mathrm{x}$ & $\mathrm{x}$ & $\mathrm{x}$ & $\mathrm{R}$ & $\mathrm{x}$ & $\mathrm{x}$ \\
\hline Bangladesh & $\mathrm{R}$ & $\mathrm{x}$ & $\mathrm{x}$ & $\mathrm{R}$ & $\mathrm{R}$ & $\mathrm{S}$ & $\mathrm{R} \circledast$ & $\mathrm{R}$ & $\mathrm{R}$ & $\mathrm{x}$ & $\mathrm{R}$ & $\mathrm{R}$ & $\mathrm{R}$ \\
\hline Barbados & $\mathrm{R}$ & $\mathrm{R}$ & $\mathrm{x}$ & $\mathrm{R}$ & $\mathrm{R}$ & $\mathrm{x}$ & $\mathrm{R}$ & $\mathrm{x}$ & $\mathrm{x}$ & $\mathrm{x}$ & $\mathrm{R}$ & $\mathrm{x}$ & $\mathrm{x}$ \\
\hline Belize & $\mathrm{R}$ & $\mathrm{x}$ & $\mathrm{x}$ & S & $\mathrm{R}$ & $\mathrm{R}$ & $\mathrm{R}$ & $\mathrm{R}$ & $\mathrm{R}$ & $\mathrm{x}$ & $\mathrm{R}$ & $\mathrm{R}$ & $\mathrm{R}$ \\
\hline Botswana & $\mathrm{R}$ & $\mathrm{x}$ & $\mathrm{x}$ & $\mathrm{x}$ & $\mathrm{R}$ & $\mathrm{x}$ & $\mathrm{R}$ & $\mathrm{R}$ & $\mathrm{R}$ & $\mathrm{x}$ & $\mathrm{R}$ & $\mathrm{R}$ & $\mathrm{R}$ \\
\hline Brunei & $\mathrm{x}$ & $\mathrm{x}$ & $\mathrm{x}$ & $\mathrm{x}$ & $\mathrm{x}$ & $\mathrm{x}$ & $\mathrm{R}$ & $\mathrm{x}$ & $\mathrm{x}$ & $\mathrm{x}$ & $\mathrm{R}$ & $\mathrm{x}$ & $\mathrm{R}$ \\
\hline Cameroon & $\mathrm{R}$ & $\mathrm{R}$ & $\mathrm{x}$ & $\mathrm{R}$ & $\mathrm{R}$ & $\mathrm{x}$ & $\mathrm{R}$ & $\mathrm{R}$ & $\mathrm{R}$ & $\mathrm{x}$ & $\mathrm{R}$ & S & S \\
\hline Canada & $\mathrm{R}$ & $\mathrm{R}$ & $\mathrm{R}$ & $\mathrm{R}$ & $\mathrm{R}$ & $\mathrm{x}$ & $\mathrm{R}$ & $\mathrm{R}$ & $\mathrm{R}$ & $\mathrm{x}$ & $\mathrm{R}$ & $\mathrm{R}$ & $\mathrm{R}$ \\
\hline Cyprus & $\mathrm{R}$ & $\mathrm{R}$ & $\mathrm{R}$ & $\mathrm{R}$ & $\mathrm{R}$ & $\mathrm{x}$ & $\mathrm{R} \circledast$ & $\mathrm{R}$ & $\mathrm{R}$ & S & $\mathrm{R}$ & $\mathrm{x}$ & $\mathrm{R}$ \\
\hline Dominica & $\mathrm{R}$ & $\mathrm{x}$ & $\mathrm{x}$ & $\mathrm{R}$ & $\mathrm{x}$ & $\mathrm{x}$ & $\mathrm{R}$ & $\mathrm{x}$ & $\mathrm{x}$ & $\mathrm{x}$ & $\mathrm{R}$ & $\mathrm{R}$ & $\mathrm{R}$ \\
\hline Fiji Islands & $\mathrm{x}$ & $\mathrm{x}$ & $\mathrm{x}$ & $\mathrm{x}$ & $\mathrm{R}$ & $\mathrm{x}$ & $\mathrm{R} \circledast$ & $\mathrm{x}$ & $\mathrm{x}$ & $\mathrm{x}$ & $\mathrm{R}$ & S & S \\
\hline Gambia & $\mathrm{R}$ & $\mathrm{R}$ & $\mathrm{x}$ & $\mathrm{R}$ & $\mathrm{R}$ & $\mathrm{x}$ & $\mathrm{R}$ & $\mathrm{x}$ & S & $\mathrm{x}$ & $\mathrm{R}$ & S & $\mathrm{S}$ \\
\hline Ghana & $\mathrm{R}$ & $\mathrm{R}$ & $\mathrm{x}$ & $\mathrm{R}$ & $\mathrm{R}$ & $\mathrm{R}$ & $\mathrm{R}$ & S & $\mathrm{R}$ & S & $\mathrm{R}$ & S & $\mathrm{S}$ \\
\hline Grenada & $\mathrm{R}$ & $\mathrm{x}$ & $\mathrm{x}$ & $\mathrm{R}$ & $\mathrm{S}$ & $\mathrm{x}$ & $\mathrm{R}$ & $\mathrm{x}$ & $\mathrm{x}$ & $\mathrm{x}$ & $\mathrm{R}$ & $\mathrm{x}$ & $\mathrm{x}$ \\
\hline Guyana & $\mathrm{R}$ & $\mathrm{R} \circledast$ & $\mathrm{x}$ & $\mathrm{R}$ & $\mathrm{R}$ & S & $\mathrm{R}$ & $\mathrm{x}$ & $\mathrm{R}$ & $\mathrm{x}$ & $\mathrm{R}$ & $\mathrm{x}$ & $\mathrm{x}$ \\
\hline India & $\mathrm{R}$ & $\mathrm{x}$ & $\mathrm{x}$ & $\mathrm{R}$ & $\mathrm{R}$ & $\mathrm{x}$ & $\mathrm{R} \circledast$ & $\mathrm{x}$ & S & $\mathrm{x}$ & $\mathrm{R}$ & $\mathrm{R}$ & $\mathrm{R}$ \\
\hline Jamaica & $\mathrm{R}$ & D & $\mathrm{x}$ & $\mathrm{R}$ & $\mathrm{R}$ & $\mathrm{x}$ & $\mathrm{R} \circledast$ & $\mathrm{x}$ & $\mathrm{x}$ & $\mathrm{x}$ & $\mathrm{R}$ & $\mathrm{R}$ & $\mathrm{S}$ \\
\hline Kenya & $\mathrm{R}$ & $\mathrm{x}$ & $\mathrm{x}$ & $\mathrm{R}$ & $\mathrm{R}$ & $\mathrm{x}$ & $\mathrm{R}$ & $\mathrm{x}$ & $\mathrm{R}$ & $\mathrm{x}$ & $\mathrm{R}$ & $\mathrm{R}$ & $\mathrm{S}$ \\
\hline Kiribati & $\mathrm{x}$ & $\mathrm{x}$ & $\mathrm{x}$ & $\mathrm{x}$ & $\mathrm{x}$ & $\mathrm{x}$ & $\mathrm{R}$ & $\mathrm{x}$ & $\mathrm{x}$ & $\mathrm{x}$ & $\mathrm{R}$ & $\mathrm{x}$ & $\mathrm{x}$ \\
\hline Lesotho & $\mathrm{R}$ & $\mathrm{R}$ & $\mathrm{x}$ & $\mathrm{R}$ & $\mathrm{x}$ & $\mathrm{R}$ & $\mathrm{R} \circledast$ & $\mathrm{R}$ & $\mathrm{R}$ & $\mathrm{x}$ & $\mathrm{R}$ & $\mathrm{R}$ & $\mathrm{R}$ \\
\hline Malawi & $\mathrm{R}$ & $\mathrm{R}$ & $\mathrm{x}$ & $\mathrm{R}$ & $\mathrm{x}$ & $\mathrm{x}$ & $\mathrm{R}$ & S & $\mathrm{R}$ & $\mathrm{x}$ & $\mathrm{R}$ & S & S \\
\hline Malaysia & $\mathrm{x}$ & $\mathrm{x}$ & $\mathrm{x}$ & $\mathrm{x}$ & $\mathrm{x}$ & $\mathrm{x}$ & $\mathrm{R} \circledast$ & $\mathrm{x}$ & $\mathrm{x}$ & $\mathrm{x}$ & $\mathrm{R}$ & $\mathrm{x}$ & $\mathrm{x}$ \\
\hline Maldives & $\mathrm{R}$ & $\mathrm{R}$ & $\mathrm{x}$ & $\mathrm{R}$ & $\mathrm{R}$ & $\mathrm{x}$ & $\mathrm{R} \circledast$ & $\mathrm{R}$ & $\mathrm{R}$ & $\mathrm{R}$ & $\mathrm{R}$ & $\mathrm{R}$ & $\mathrm{R}$ \\
\hline Malta & $\mathrm{R}$ & $\mathrm{R}$ & $\mathrm{R}$ & $\mathrm{R}$ & $\mathrm{R}$ & $\mathrm{x}$ & $\mathrm{R} \circledast$ & $\mathrm{x}$ & $\mathrm{R}$ & $\mathrm{R}$ & $\mathrm{R}$ & $\mathrm{R}$ & $S$ \\
\hline Mauritius & $\mathrm{R}$ & $\mathrm{R}$ & $\mathrm{x}$ & $\mathrm{R}$ & $\mathrm{R}$ & $\mathrm{x}$ & $\mathrm{R} \circledast$ & S & $\mathrm{R}$ & $\mathrm{R}$ & $\mathrm{R}$ & S & $\mathrm{S}$ \\
\hline Mozambique & $\mathrm{R}$ & $\mathrm{x}$ & $\mathrm{R}$ & $\mathrm{x}$ & $\mathrm{R}$ & $\mathrm{x}$ & $\mathrm{R}$ & $\mathrm{x}$ & $\mathrm{R}$ & $\mathrm{x}$ & $\mathrm{R}$ & $\mathrm{R}$ & $\mathrm{R}$ \\
\hline Namibia & $\mathrm{R}$ & $\mathrm{R}$ & $\mathrm{R}$ & $\mathrm{R}$ & $\mathrm{R}$ & $\mathrm{x}$ & $\mathrm{R}$ & $\mathrm{R}$ & $\mathrm{R}$ & $\mathrm{x}$ & $\mathrm{R}$ & $\mathrm{R}$ & $\mathrm{R}$ \\
\hline Nauru & S & S & $\mathrm{x}$ & $\mathrm{x}$ & S & $\mathrm{x}$ & $\mathrm{x}$ & $\mathrm{x}$ & S & $\mathrm{x}$ & $\mathrm{R}$ & S & S \\
\hline New Zealand & $\mathrm{R} \circledast$ & $\mathrm{R}$ & $\mathrm{R}$ & $\mathrm{R}$ & $\mathrm{R}$ & $\mathrm{x}$ & $\mathrm{R}$ & $\mathrm{R}$ & $\mathrm{R}$ & $\mathrm{R}$ & $\mathrm{R} \circledast$ & $\mathrm{R}$ & S \\
\hline Nigeria & $\mathrm{R}$ & $\mathrm{x}$ & $\mathrm{x}$ & $\mathrm{R}$ & $\mathrm{R}$ & $\mathrm{x}$ & $\mathrm{R}$ & $\mathrm{R}$ & $\mathrm{R}$ & $\mathrm{x}$ & $\mathrm{R}$ & S & $\mathrm{S}$ \\
\hline Pakistan & $\mathrm{x}$ & $\mathrm{x}$ & $\mathrm{x}$ & S & $\mathrm{R}$ & $\mathrm{x}$ & $\mathrm{R} \circledast$ & $\mathrm{x}$ & $\mathrm{x}$ & $\mathrm{x}$ & $\mathrm{R}$ & S & S \\
\hline Papua New Guinea & $\mathrm{x}$ & $\mathrm{x}$ & $\mathrm{x}$ & $\mathrm{x}$ & $\mathrm{R}$ & $\mathrm{x}$ & $\mathrm{R}$ & $\mathrm{x}$ & $\mathrm{x}$ & $\mathrm{x}$ & $\mathrm{R}$ & $\mathrm{x}$ & $\mathrm{x}$ \\
\hline
\end{tabular}




\begin{tabular}{|c|c|c|c|c|c|c|c|c|c|c|c|c|c|}
\hline COUNTRY & ICCPR & $\begin{array}{c}\text { OP I } \\
\text { ICCPR }\end{array}$ & $\begin{array}{c}\text { OP II } \\
\text { ICCPR }\end{array}$ & $\begin{array}{l}\text { ICE } \\
\text { SCR }\end{array}$ & ICERD & ICRMW & CEDAW & $\begin{array}{c}\text { OP } \\
\text { CEDAW }\end{array}$ & CAT & $\begin{array}{c}\text { OP } \\
\text { CAT }\end{array}$ & CRC & $\begin{array}{c}\text { OP } \\
\text { CRC } \\
\text { AC }\end{array}$ & $\begin{array}{c}\text { OP } \\
\text { CRC } \\
\text { SC }\end{array}$ \\
\hline Samoa & $\mathrm{x}$ & $\mathrm{x}$ & $\mathrm{x}$ & $\mathrm{x}$ & $\mathrm{x}$ & $\mathrm{x}$ & $\mathrm{R}$ & $\mathrm{x}$ & $\mathrm{x}$ & $\mathrm{x}$ & $\mathrm{R}$ & $\mathrm{x}$ & $\mathrm{x}$ \\
\hline Seychelles & $\mathrm{R}$ & $\mathrm{R}$ & $\mathrm{R}$ & $\mathrm{R}$ & $\mathrm{R}$ & $\mathrm{R}$ & $\mathrm{R}$ & $\mathrm{S}$ & $\mathrm{R}$ & $\mathrm{x}$ & $\mathrm{R}$ & $\mathrm{S}$ & $\mathrm{S}$ \\
\hline Sierra Leone & $\mathrm{R}$ & $\mathrm{R}$ & $\mathrm{x}$ & $\mathrm{R}$ & $\mathrm{R}$ & $\mathrm{S}$ & $\mathrm{R}$ & $\mathrm{S}$ & $\mathrm{R}$ & $\mathrm{S}$ & $\mathrm{R}$ & $\mathrm{R}$ & $\mathrm{R}$ \\
\hline Singapore & $\mathrm{x}$ & $\mathrm{x}$ & $\mathrm{x}$ & $\mathrm{x}$ & $\mathrm{x}$ & $\mathrm{x}$ & $\mathrm{R} \circledast$ & $\mathrm{x}$ & $\mathrm{x}$ & $\mathrm{x}$ & $\mathrm{R}$ & S & $\mathrm{x}$ \\
\hline Solomon Islands & $\mathrm{x}$ & $\mathrm{x}$ & $\mathrm{x}$ & $\mathrm{R} \circledast$ & $\mathrm{R}$ & $\mathrm{x}$ & $\mathrm{R}$ & $\mathrm{R}$ & $\mathrm{x}$ & $\mathrm{x}$ & $\mathrm{R}$ & $\mathrm{x}$ & $\mathrm{x}$ \\
\hline South Africa & $\mathrm{R}$ & $\mathrm{R}$ & $\mathrm{R}$ & $\mathrm{S}$ & $\mathrm{R}$ & $\mathrm{x}$ & $\mathrm{R}$ & $\mathrm{R}$ & $\mathrm{R}$ & $\mathrm{S}$ & $\mathrm{R}$ & $\mathrm{S}$ & $\mathrm{R}$ \\
\hline Sri Lanka & $\mathrm{R}$ & $\mathrm{R}$ & $\mathrm{x}$ & $\mathrm{R}$ & $\mathrm{R}$ & $\mathrm{R}$ & $\mathrm{R}$ & $\mathrm{R}$ & $\mathrm{R}$ & $\mathrm{x}$ & $\mathrm{R}$ & $\mathrm{R}$ & $\mathrm{R}$ \\
\hline St. Kitts and Nevis & $\mathrm{x}$ & $\mathrm{x}$ & $\mathrm{x}$ & $\mathrm{x}$ & $\mathrm{R}$ & $\mathrm{x}$ & $\mathrm{R}$ & $\mathrm{R}$ & $\mathrm{x}$ & $\mathrm{x}$ & $\mathrm{R}$ & $\mathrm{x}$ & $\mathrm{x}$ \\
\hline St. Lucia & $\mathrm{x}$ & $\mathrm{x}$ & $\mathrm{x}$ & $\mathrm{x}$ & $\mathrm{R}$ & $\mathrm{x}$ & $\mathrm{R}$ & $\mathrm{x}$ & $\mathrm{x}$ & $\mathrm{x}$ & $\mathrm{R}$ & $\mathrm{x}$ & $\mathrm{x}$ \\
\hline St. Vincent and Grenadines & es $x$ & $\mathrm{R}$ & $\mathrm{x}$ & $\mathrm{R}$ & $\mathrm{R}$ & $\mathrm{x}$ & $\mathrm{R}$ & $\mathrm{x}$ & $\mathrm{R}$ & $\mathrm{x}$ & $\mathrm{R}$ & $\mathrm{x}$ & $\mathrm{R}$ \\
\hline Swaziland & $\mathrm{R}$ & $\mathrm{x}$ & $\mathrm{x}$ & $\mathrm{R}$ & $\mathrm{R}$ & $\mathrm{x}$ & $\mathrm{R}$ & $\mathrm{x}$ & $\mathrm{R}$ & $\mathrm{x}$ & $\mathrm{R}$ & $\mathrm{x}$ & $\mathrm{x}$ \\
\hline Tanzania & $\mathrm{R}$ & $\mathrm{x}$ & $\mathrm{x}$ & $\mathrm{R}$ & $\mathrm{R}$ & $\mathrm{x}$ & $\mathrm{R}$ & $\mathrm{R}$ & $\mathrm{x}$ & $\mathrm{x}$ & $\mathrm{R}$ & $\mathrm{R}$ & $\mathrm{R}$ \\
\hline Tonga & $\mathrm{x}$ & $\mathrm{x}$ & $\mathrm{x}$ & $\mathrm{x}$ & $\mathrm{R}$ & $\mathrm{x}$ & $\mathrm{x}$ & $\mathrm{x}$ & $\mathrm{x}$ & $\mathrm{x}$ & $\mathrm{R}$ & $\mathrm{x}$ & $\mathrm{x}$ \\
\hline Trinidad and Tobago & $\mathrm{R}$ & $\mathrm{D}$ & $\mathrm{x}$ & $\mathrm{R}$ & $\mathrm{R}$ & $\mathrm{x}$ & $\mathrm{R} \circledast$ & $\mathrm{x}$ & $\mathrm{x}$ & $\mathrm{x}$ & $\mathrm{R}$ & $\mathrm{x}$ & $\mathrm{x}$ \\
\hline Tuvalu & $\mathrm{x}$ & $\mathrm{x}$ & $\mathrm{x}$ & $\mathrm{x}$ & $\mathrm{x}$ & $\mathrm{x}$ & $\mathrm{R}$ & $\mathrm{x}$ & $\mathrm{x}$ & $\mathrm{x}$ & $\mathrm{R}$ & $\mathrm{x}$ & $\mathrm{x}$ \\
\hline Uganda & $\mathrm{R}$ & $\mathrm{R}$ & $\mathrm{x}$ & $\mathrm{R}$ & $\mathrm{R}$ & $\mathrm{R}$ & $\mathrm{R}$ & $\mathrm{x}$ & $\mathrm{R}$ & $\mathrm{x}$ & $\mathrm{R}$ & $\mathrm{R}$ & $\mathrm{R}$ \\
\hline United Kingdom & $\mathrm{R} \circledast$ & $\mathrm{x}$ & $\mathrm{R}$ & $\mathrm{R} \circledast$ & $\mathrm{R} \circledast$ & $\mathrm{x}$ & $\mathrm{R} \circledast$ & $\mathrm{R}$ & $\mathrm{R} \circledast$ & $\mathrm{R}$ & $\mathrm{R} \circledast$ & $\mathrm{R}$ & S \\
\hline Vanuatu & $\mathrm{x}$ & $\mathrm{x}$ & $\mathrm{x}$ & $\mathrm{x}$ & $\mathrm{x}$ & $\mathrm{x}$ & $\mathrm{R}$ & $\mathrm{R}$ & $\mathrm{x}$ & $\mathrm{x}$ & $\mathrm{R}$ & $\mathrm{S}$ & S \\
\hline Zambia & $\mathrm{R}$ & $\mathrm{R}$ & $\mathrm{x}$ & $\mathrm{R}$ & $\mathrm{R}$ & $\mathrm{x}$ & $\mathrm{R}$ & $\mathrm{x}$ & $\mathrm{R}$ & $\mathrm{x}$ & $\mathrm{R}$ & $\mathrm{x}$ & $\mathrm{x}$ \\
\hline
\end{tabular}

\section{CHART}

R : Ratification; Succession; Accession

$\mathrm{S}$ : Signature

D : Denunciation

(B) : Reservations or Declarations

ICCPR : International Covenant on Civil and Political Rights

OPIICCPR : Optional Protocol to the International Covenant on Civil and Political Rights

OP II ICCPR : Second Optional Protocol to the International Covenant on Civil and Political Rights, aiming at the abolition of the death penalty

ICESCR : International Covenant on Economic, Social and Cultural Rights

ICERD : International Covention on the Elimination of all forms of Racial Discrimination

ICRMW : International Convention on the Protection of the Rights of All Migrant Workers and Members of Their Families

CEDAW : Convention on the Elimination of All Forms of Discrimination against Women

OPCEDAW : Optional Protocol to the Convention on the Elimination of All Forms of Discrimination against Women

CAT : Convention against Torture and Other Cruel, Inhuman or Degrading Treatment or Punishment

OPCAT : Optional Protocol to the Convention against Torture and Other Cruel, Inhuman or Degrading Treatment or Punishment

CRC : Convention on the Rights of the Child

OPCRCAC : Optional Protocol to the Convention on the Rights of the Child on involvement of children in armed conflict

OPCRCSC : Optional Protocol to the Convention on the Rights of the Child on the sale of children, child prostitution and child pornography 


\section{APPENDIX IV}

Ratification of counter-terrorism conventions by Commonwealth countries

CSUAMN PSUAMN PSUAA CSFT CSTB CSNT CATH CPPNM CMPE CSUSA CSUACA PPCIPP COCBA

\begin{tabular}{|c|c|c|c|c|c|c|c|c|c|c|c|c|c|}
\hline \multicolumn{4}{|l|}{ Antigua and Barbuda } & \multicolumn{3}{|l|}{$\mathrm{R}$} & $\mathrm{R}$ & \multicolumn{2}{|l|}{$\mathrm{R}$} & $\mathrm{R}$ & $\mathrm{R}$ & $\mathrm{R}$ & $\mathrm{R}$ \\
\hline Australia & $\mathrm{R}$ & $\mathrm{R}$ & $\mathrm{R}$ & $\mathrm{R}$ & $\mathrm{R}$ & $\mathrm{S}$ & $\mathrm{R}$ & $\mathrm{R}$ & & $\mathrm{R}$ & $\mathrm{R}$ & $\mathrm{R}$ & $\mathrm{R}$ \\
\hline The Bahamas & $\mathrm{R}$ & $\mathrm{R}$ & & $\mathrm{R} \circledast$ & & & $\mathrm{R}$ & & & $\mathrm{R}$ & $\mathrm{R}$ & $\mathrm{R}$ & $\mathrm{R} \circledast$ \\
\hline Bangladesh & $\mathrm{R}$ & $\mathrm{R}$ & $\mathrm{R}$ & $\mathrm{R} \circledast$ & $\mathrm{R}$ & $\mathrm{R} \circledast$ & $\mathrm{R}$ & $\mathrm{R}$ & R1 & $\mathrm{R}$ & $\mathrm{R}$ & $\mathrm{R}$ & $\mathrm{R}$ \\
\hline Barbados & $\mathrm{R}$ & $\mathrm{R}$ & $\mathrm{R}$ & $\mathrm{R}$ & $\mathrm{R}$ & & $\mathrm{R}$ & & R1 & $\mathrm{R}$ & $\mathrm{R}$ & $\mathrm{R}$ & $\mathrm{R}$ \\
\hline Belize & & & $\mathrm{R}$ & $\mathrm{R}$ & $\mathrm{R}$ & & & & S & $\mathrm{R}$ & $\mathrm{R}$ & $\mathrm{R}$ & $\mathrm{R}$ \\
\hline Botswana & $\mathrm{R}$ & $\mathrm{R}$ & $\mathrm{R}$ & $\mathrm{R}$ & $\mathrm{R}$ & & $\mathrm{R}$ & $\mathrm{R}$ & R1 & $\mathrm{R}$ & $\mathrm{R}$ & $\mathrm{R}$ & $\mathrm{R}$ \\
\hline Brunei Darussalam & $\mathrm{R}$ & $\mathrm{R}$ & $\mathrm{R}$ & $\mathrm{R}$ & $\mathrm{R}$ & & $\mathrm{R}$ & & & $\mathrm{R}$ & $\mathrm{R}$ & $\mathrm{R}$ & $\mathrm{R}$ \\
\hline Cameroon & & & $\mathrm{R}$ & $\mathrm{R}$ & $\mathrm{R}$ & & $\mathrm{R}$ & $\mathrm{R}$ & $\mathrm{R} 1$ & $\mathrm{R}$ & $\mathrm{R}(\mathbb{2}$ & $\mathrm{R}$ & $\mathrm{R}$ \\
\hline Canada & $\mathrm{R}$ & $\mathrm{R}$ & $\mathrm{R}$ & $\mathrm{R}$ & $\mathrm{R} \circledast$ & $\mathrm{S}$ & $\mathrm{R}$ & $\mathrm{R}$ & R2 & $\mathrm{R}$ & $\mathrm{R}$ & $\mathrm{R}$ & $\mathrm{R}$ \\
\hline Cyprus & $\mathrm{R}$ & $\mathrm{R}$ & $\mathrm{R}$ & $\mathrm{R}$ & $\mathrm{R}$ & $\mathrm{S}$ & $\mathrm{R}$ & $\mathrm{R} \otimes$ & R1 & $\mathrm{R}$ & $\mathrm{R}$ & $\mathrm{R}$ & $\mathrm{R}$ \\
\hline Dominica & $\mathrm{R}$ & $\mathrm{R}$ & $\mathrm{R}$ & $\mathrm{R}$ & $\mathrm{R}$ & & $\mathrm{R} \circledast$ & $\mathrm{R}$ & & $\mathrm{R}$ & $\mathrm{R}$ & $\mathrm{R}$ & \\
\hline Fiji Islands & & & $\mathrm{R}$ & & & & & & & $\mathrm{R}$ & $\mathrm{R}$ & & $\mathrm{R} \circledast$ \\
\hline The Gambia & $\mathrm{R}$ & & $\mathrm{R}$ & & & & & & R1 & $\mathrm{R}$ & $\mathrm{R}$ & & $\mathrm{R}$ \\
\hline Ghana & $\mathrm{R}$ & $\mathrm{R}$ & $\mathrm{R}$ & $\mathrm{R}$ & $\mathrm{R}$ & $\mathrm{S}$ & $\mathrm{R}$ & $\mathrm{R}$ & R1 & $\mathrm{R}$ & $\mathrm{R}$ & $\mathrm{R} \circledast$ & $\mathrm{R}$ \\
\hline Grenada & $\mathrm{R}$ & $\mathrm{R}$ & $\mathrm{R}$ & $\mathrm{R}$ & $\mathrm{R}$ & & $\mathrm{R}$ & $\mathrm{R}$ & $\mathrm{R} 1$ & $\mathrm{R}$ & $\mathrm{R}$ & $\mathrm{R}$ & $\mathrm{R}$ \\
\hline Guyana & $\mathrm{R}$ & $\mathrm{R}$ & $\mathrm{R}$ & & & S & & & & $\mathrm{R}$ & $\mathrm{R}$ & & $\mathrm{R}$ \\
\hline India & $\mathrm{R}$ & $\mathrm{R}$ & $\mathrm{R}$ & $\mathrm{R}$ & $\mathrm{R} \circledast$ & $\mathrm{R} \circledast$ & $\mathrm{R} \circledast$ & $\mathrm{R} \circledast$ & $\mathrm{R} \otimes$ & $\mathrm{R} \otimes$ & $\mathrm{R}$ & $\mathrm{R} \otimes$ & $\mathrm{R} \otimes$ \\
\hline Jamaica & $\mathrm{R}$ & $\mathrm{R}$ & $\mathrm{R}$ & $\mathrm{R}$ & $\mathrm{R}$ & $\mathrm{S}$ & $\mathrm{R}$ & $\mathrm{R}$ & R1 & $\mathrm{R}$ & $\mathrm{R}$ & $\mathrm{R}{ }^{\circledR}$ & $\mathrm{R}$ \\
\hline Kenya & $\mathrm{R}$ & $\mathrm{R}$ & $\mathrm{R}$ & $\mathrm{R}$ & $\mathrm{R}$ & $\mathrm{R}$ & $\mathrm{R} \circledast$ & $\mathrm{R}$ & R1 & $\mathrm{R}$ & $\mathrm{R}$ & $\mathrm{R}$ & $\mathrm{R}$ \\
\hline Kiribati & $\mathrm{R}$ & $\mathrm{R}$ & & $\mathrm{R}$ & $\mathrm{R}$ & $\mathrm{S}$ & $\mathrm{R}$ & & & & & $\mathrm{R}$ & \\
\hline Lesotho & & & & $\mathrm{R}$ & $\mathrm{R}$ & $\mathrm{S}$ & $\mathrm{R}$ & & & $\mathrm{R}$ & $\mathrm{R}$ & & $\mathrm{R}$ \\
\hline Malawi & & & S & $\mathrm{R}$ & $\mathrm{R}$ & & $\mathrm{R} \circledast$ & & & $\mathrm{R} \circledast$ & $\mathrm{R}(\mathbb{2}$ & $\mathrm{R} \circledast$ & $\mathrm{R} \circledast$ \\
\hline Malaysia & & & $\mathrm{R}$ & $\mathrm{R} \circledast$ & $\mathrm{R} \circledast$ & $\mathrm{S}$ & $\mathrm{R} \otimes$ & & & $\mathrm{R}$ & $\mathrm{R}$ & $R \circledast$ & $\mathrm{R}$ \\
\hline Maldives & & & $\mathrm{R}$ & $\mathrm{R}$ & $\mathrm{R}$ & & & & R1 & $\mathrm{R}$ & $\mathrm{R}$ & $\mathrm{R}$ & $\mathrm{R}$ \\
\hline Malta & $\mathrm{R}$ & $\mathrm{R}$ & $\mathrm{R}$ & $\mathrm{R}$ & $\mathrm{R}$ & $\mathrm{S}$ & $\mathrm{R}$ & $\mathrm{R}$ & R1 & $\mathrm{R}$ & $\mathrm{R}$ & $\mathrm{R}$ & $\mathrm{R}$ \\
\hline Mauritius & $\mathrm{R}$ & $\mathrm{R}$ & $\mathrm{R}$ & $\mathrm{R}$ & $\mathrm{R}$ & S & $\mathrm{R}$ & & S & $\mathrm{R}$ & $\mathrm{R}$ & $\mathrm{R}{ }^{\circledR}$ & $\mathrm{R}$ \\
\hline Mozambique & $\mathrm{R}$ & $\mathrm{R}$ & $\mathrm{R}$ & $\mathrm{R}$ & $\mathrm{R}{ }^{\circledR}$ & $\mathrm{S}$ & $\mathrm{R} \circledast$ & $\mathrm{R} \circledast$ & $\mathrm{R} \circledast 1$ & $\mathrm{R}$ & $\mathrm{R}(\mathbb{R}$ & $\mathrm{R} \otimes$ & $\mathrm{R}(\mathbb{R}$ \\
\hline Namibia & $\mathrm{R}$ & $\mathrm{R}$ & $\mathrm{R}$ & $\mathrm{S}$ & & & & $\mathrm{R}$ & & $\mathrm{R}$ & $\mathrm{R}$ & & $\mathrm{R}$ \\
\hline Nauru & $\mathrm{R}$ & $\mathrm{R}$ & $\mathrm{R}$ & $\mathrm{R}$ & $\mathrm{R}$ & & $\mathrm{R}$ & $\mathrm{R}$ & R1 & $\mathrm{R}$ & $\mathrm{R}$ & $\mathrm{R}$ & $\mathrm{R}$ \\
\hline New-Zealand & $\mathrm{R}$ & $\mathrm{R}$ & $\mathrm{R}$ & $\mathrm{R}$ & $\mathrm{R}$ & $\mathrm{S}$ & $\mathrm{R}$ & $\mathrm{R}$ & $\mathrm{R} \circledast 1$ & $\mathrm{R}$ & $\mathrm{R}$ & $\mathrm{R}(\mathbb{2}$ & $\mathrm{R}(\mathbb{2}$ \\
\hline Nigeria & $\mathrm{R}$ & & $\mathrm{R}$ & $\mathrm{R}$ & & & & $\mathrm{R}$ & R1 & $\mathrm{R}$ & $\mathrm{R}$ & & $\mathrm{R}$ \\
\hline Pakistan & $\mathrm{R}$ & $\mathrm{R}$ & $\mathrm{R}$ & & $\mathrm{R}{ }^{\circledR}$ & & $\mathrm{R}$ & $\mathrm{R} \circledast$ & $\mathrm{S}$ & $\mathrm{R}$ & $\mathrm{R}$ & $\mathrm{R} \circledast$ & $\mathrm{R}$ \\
\hline Papua New Guinea & & & $\mathrm{R}$ & $\mathrm{R}$ & $\mathrm{R}$ & & $\mathrm{R}$ & & & $\mathrm{R} \otimes$ & $\mathrm{R} \otimes$ & $\mathrm{R}$ & $\mathrm{R} \circledast$ \\
\hline
\end{tabular}


CSUAMN PSUAMN PSUAA CSFT CSTB CSNT CATH CPPNM CMPE CSUSA CSUACA PPCIPP COCBA

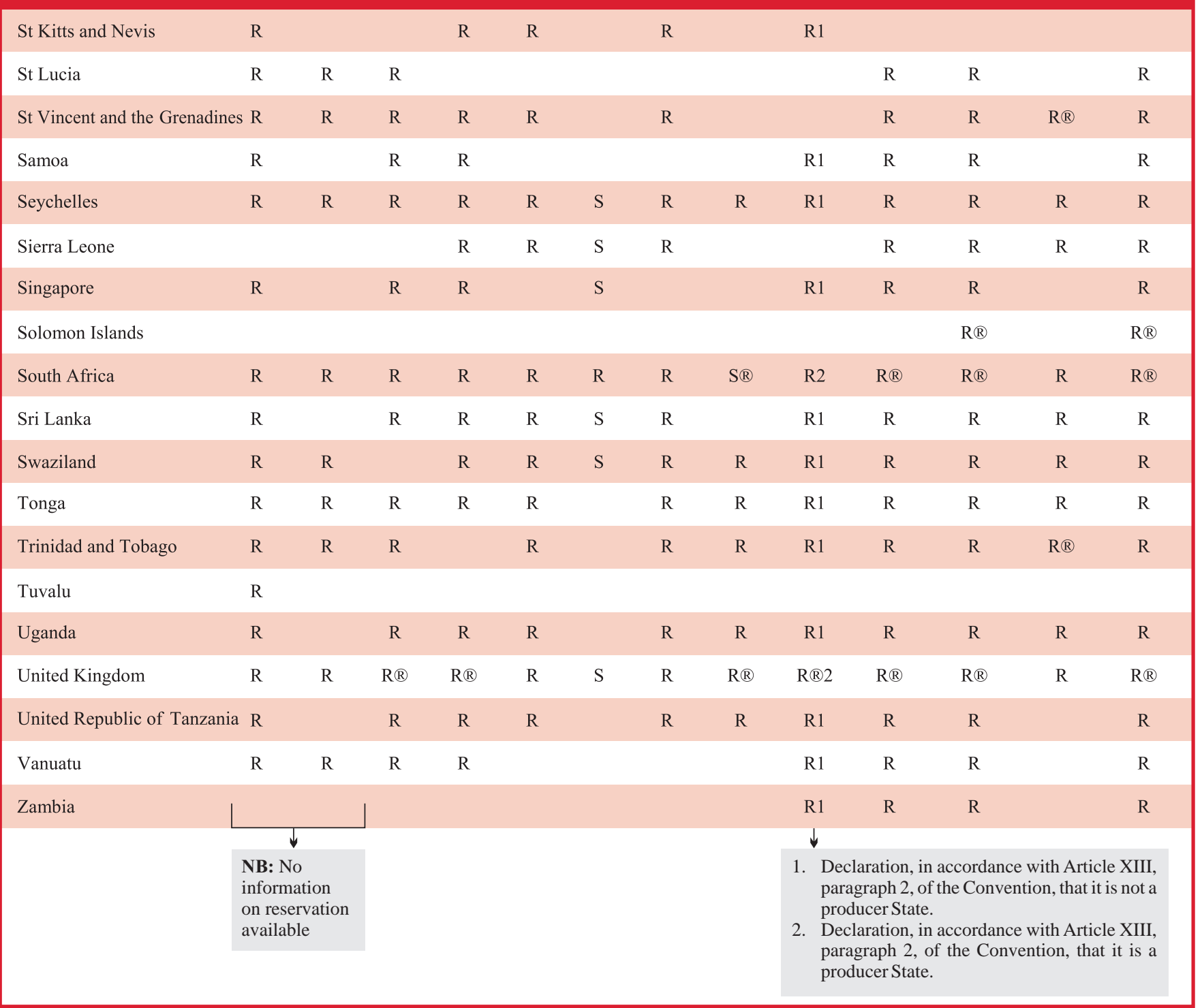

\footnotetext{
Chart:

$\mathrm{R} \quad$ : Ratification, succession, accession

$\mathrm{S} \quad$ : Signature

(B) : Reservation or declaration
}

CSUAMN : Convention for the Suppression of Unlawful Acts against the Safety of Maritime Navigation, done at Rome on 10 March 1988

PSUAMN : Protocol for the Suppression of Unlawful Acts against the Safety of Fixed Platforms Located on the Continental Shelf, done at Rome on 10 March 1988

PSUAA : Protocol For The Suppression Of Unlawful Acts Of Violence At Airports Serving International Civil Aviation, Supplementary To The Convention For The Suppression Of Unlawful Acts Against The Safety Of Civil Aviation, Done At Montreal On 23 September 1971

CSFT

CSTB

CSNT

CATH

CPPNM

CMPE

CSUSA

CSUACA

PPCIPP

International Convention for the Suppression of the Financing of Terrorism New York, 9 December 1999

International Convention for the Suppression of Terrorist Bombings New York, 15 December 1997

International Convention for the Suppression of Acts of Nuclear Terrorism New York, 13 April 2005

International Convention Against the Taking of Hostages New York, 17 December 1979

Convention on the Physical Protection of Nuclear Material on 8 February 1987

Convention On The Marking Of Plastic Explosives For The Purpose Of Detection Done At Montreal On 1 March 1991

Convention For The Suppression Of Unlawful Seizure Of Aircraft Signed At The Hague On 16 December 1970

Convention For The Suppression Of Unlawful Acts Against The Safety Of Civil Aviation Signed At Montreal On 23 September 1971

COCBA

Convention On Offences And Certain Other Acts Committed On Board Aircraft Signed At Tokyo On 14 September 1963 


\section{ENDNOTES}

\section{Chapter 1}

1 United Nations General Assembly (1948) Universal Declaration of Human Rights, Preamble: http://www.un.org/Overview/rights.html as on 12 July 2007; Office of the High Commissioner for Human Rights (1966) International Covenant on Civil and Political Rights, Preamble: http://www.unhchr.ch/html/menu3/b/a_ccpr.htm as on 12 July 2007; Office of the High Commissioner for Human Rights (1966) International Covenant on Economic, Social and Cultural Rights, Preamble: http://www.unhchr.ch/html/menu3/b/a_cescr.htm as on 12 July 2007

2 Dutt, V, Srikanth, VR and Nagi, S (2007) 'UK Terror: Jeep bomber also Indian', Hindustan Times, 5 July: http://www.hindustantimes.com/htsite/StoryPage/FullcoverageStoryPage.aspx?id=b54a4d7c-607f-4e4b-8f07 813a2d94122findiandocsinukterrorplot_ Special\&MatchID1=4500\&TeamID1=2\&TeamID2=6\&MatchType $1=1 \&$ SeriesID1=1122\&MatchID2=4489\&TeamID3=8\&TeamID4=10\&MatchType $2=2 \&$ SeriesID2=1121\&PrimaryID=4500\&Headline=UK+terror+plot\%3a+Jeep+bomber+also+Indian as on $20 \mathrm{July} 2007$

3 Police and Criminal Evidence (PACE) Act, 1984 (United Kingdom)

4 Code of Practice H (July 2006) Police and Criminal Evidence (PACE) Act, 1984 (United Kingdom)

5 Commonwealth Heads of Government Meet (1991) Commonwealth Harare Declaration: www.thecommonwealth.org/Internal/20723/34457/ harare_commonwealth_declaration/as on 1 August 2007

6 Laithangbam, I (2004) 'Set aside proceedings against Assam Rifles personnel', The Hindu, 20 August: http://www.hinduonnet.com/thehindu/2004/08/20 /stories/2004082002841200.htm as on 7 July 2007; Organisation and structure of the Assam Rifle, Assam Rifle website: http://www.assamrifles.com/ OrgStruct.htm as on 17 July 2007

7 Section 2, Anti-Terrorism Act, 1997 (Pakistan)

8 International Secretariat of the World Organisation against Torture (2007) Bangladesh: State of emergency causing the death of at least 19 persons, including a minor, by security forces, Press Release, 26 January: http://www.crin.org/resources/infodetail.asp?id=12374 as on 27 June 2007

9 Buerk, R (2005) 'Bangladesh's Feared Elite Police', BBCNews, 13 December: http://news.bbc.uk/2/hi/south_asia/4522734.stm as on 14 June 2007

10 HURINET (2007) Break Down of the Rule of Law, Public Order, Safety and Justice, Press Release, 5 March: www.isis.or.ug/downloads/ statementonjudiciary.pdf as on 21 June 2007; HURINET (2007) Human Rights Network Uganda Calls Upon the Government to Respect and listen to the Views of Citizens, Press Release, 13 April: www.isis.or.ug/downloads/statementonjudiciary.pdf as on 15 June 2007

11 For example Sri Lankan armed forces have played a longstanding role in assisting police maintain law and order, Sri Lanka Police Service Website: http://www.police.lk/divisions/stf.asp. In the north-east states of India, the Armed Forces (Special Powers) Act of 1958 allowed Indian armed forces to carry out operations 'aiding civil power' and 'maintaining public order' once an area was declared disturbed, giving the military the role of civilian police while also giving them 'unrestricted and unaccounted power to carry out their operations': South Asia Human Rights Documentation Centre (undated) Armed Forces Special Powers Act: A Study in National Security Tyranny, http://www.hrdc.net/sahrdc/resources/armed_forces.htm as on 18 July 2007 . The AFSPA was first applied to Assam and Manipur in 1958 and then extended to all seven northeastern states of India in 1972: Assam, Manipur, Tripura, Meghalaya, Arunachal Pradesh, Mizoram and Nagaland

12 Amnesty International et al (2007) Off the Record: U.S. Responsibility for Enforced Disappearances in the 'War on Terror', http://www.statewatch.org/ news/2007/jun/us-disappeared.pdfas on 7 June 2007

13 Amnesty International (2006) Pakistan: Enforced disappearances in the 'war on terror', Press Release, 29 September: http://web.amnesty.org/ library/Index/ENGASA330382006 as on 11 July 2007

14 Amnesty International (2006) Pakistan: Enforced disappearances in the 'war on terror', Press Release, 29 September: http://web.amnesty.org/ library/Index/ENGASA330382006 as on 11 July 2007

15 Section 33(8), Internal Security Act, 1984 (Brunei Darussalam)

16 Section 47, Internal Security Act, 1984 (Brunei Darussalam)

17 Schedule 3, Division 3, Australian Security Intelligence Organisation Act, 1979 as amended by Australian Security Intelligence Organisation Legislation (Terrorism) Act 2003 (Australia)

18 Muir, H (2007) 'Muslims must help police more, urge leaders', The Hindu, 5 July, p 14: http://www.hindu.com/2007/07/05/stories/2007070551361400.htm as on 25 July 2007

19 The Convention Against Torture proscribes the following behaviour: 'any act by which severe pain or suffering, whether physical or mental, is intentionally inflicted on a person for such purposes as obtaining ... information or a confession, punishing him for an act he or a third person has committed or is suspected of having committed, or intimidating or coercing ... or for any reason based on discrimination of any kind, when such pain or suffering is inflicted by ... with the consent or acquiescence of a public official or other person acting in an official capacity': United Nations (1987) Convention Against Torture and Other forms of Cruel, Inhuman and Degrading Treatment: www.unhchr.ch/html/menu3/b/h_cat39.htm as on 1 August 2007

See also Article 5, United Nations (1948) Universal Declaration of Human Rights (UDHR): http://www.un.org/Overview/rights.html as on 27 June 2007 ; Article 7, Office of the United Nations High Commissioner of Human Rights (1966) International Covenant on Civil and Political Rights: http://www.ohchr.org/english/law/ccpr.htm as on 27 June 2007. 
20 Gonzales, A (2002) Memorandum from White House Counsel Alberto Gonzales to President Bush, 18 January: http://news.findlaw.com/usatoday/ docs/torture/gnzls12502mem2gwb2.html as on 27 June 2007

21 House of Lords of the United Kingdom (2005) A v Secretary of State for the Home Department, [2005] UKHL 71, 8 December: http://www.publications.parliament.uk/pa/ld/ldjudgmt.htm\#2005 as on 27 June 2007

22 House of Lords of the United Kingdom (2005) A v Secretary of State for the Home Department, [2005] UKHL 71, 8 December: http://www.publications.parliament.uk/pa/ld/ldjudgmt.htm\#2005 as on 27 June 2007

23 Torture was recognised as part of the jus cogens by the International Criminal Tribunal for the ex-Yugoslavia (1998) The Prosecutor v. Anto Furundzija, Case No. IT-95-17/1-T, 10 December, http://www.un.org/icty/Supplement/supp1-e/furundzija.htm as on 17 July 2007

24 See United Nations General Assembly, Implementation of general assembly resolution 60/251 of 15 March 2006 entitled 'Human Rights Council': Report of the Special Rapporteur on the promotion and protection of human rights and fundamental freedoms while countering terrorism, AA/hrc/4/26/add.1, 15 March 2007; Commonwealth Human Rights Initiative (2007) Easier Said Than Done: A report on the commitments of the Commonwealth Members of the Human Rights Council, p. 56: http://www.humanrightsinitiative.org/publications/hradvocacy/easier_said_than_done.pdf as on 17 July 2007

25 Roy, A(2006) 13 December: The strange case of the attack on the Indian Parliament, Penguin, Delhi

26 India's legislation provides immunity under section 49, Unlawful Activities (Prevention) Act 1967 (amended in 2004) for the consequences of any act committed in good faith in pursuance of that Act; under section 6, Jammu and Kashmir Disturbed Areas Act 1992; and under the section 197, Code of Criminal Procedure 1973 providing for the non liability of agents without the sanction of the government. Sri-Lanka's legislation provides for immunity for actions done in good faith under section 26, Prevention of Terrorism Act 1979; under regulation 19, Emergency Regulation 2006; and under sections 9 and 23, Public Security Ordinance 1947, where the sanction of the Attorney General is required for a prosecution. In Bangladesh, the Constitution empowers the government to extend impunity from prosecution to any state officer on any grounds (section 46), and section 34 Special Powers Act, and section 132 and 197, Code of Criminal Procedure 1898 both include immunity provisions. In Pakistan, section 39 of the Anti-terrorism Act 1997 provides for immunity for actions done in good faith.

27 Section 21H, Anti-Terrorism Act, 1997 (Pakistan)

28 Gregory, P\& Munro, I (2006) 'Conviction quashed, 'Jihad Jack' goes free', The Age, 16 August: http://www.theage.com.au/news/national/jihad-jack-goes-free/2006/08/18/1155408020814.html as on 4 July 2007

29 McKinnon, D (2005) International Human Rights Day, 10 December 2005: Message, Press Release, 9 December: http://www.thecommonwealth.org/press/34582/147750/international_human_rights_day_10_december_2005.htm as on 4 July 2007

30 See Appendix III

31 United Nations High Commission for Human Rights (2002) Concluding Observations of the Human Rights Committee: Egypt, UN Doc. CCPR/CO/76/EGY, 28 November, Para 4: http://www.unhchr.ch/tbs/doc.nsf/(Symbol)/CCPR.CO.76.EGY.En?Opendocument as on 15 June 2007

32 Conclusions and recommendations of the Committee against Torture: Colombia. 04/02/2004, CAT/C/CR/31/1. (Concluding Observations/Comments), thirty-first session, 10-21 November 2003, para 6: http://www.unhchr.ch/tbs/doc.nsf/0/c9c3cea3274f6605c1256e6800338020?Opendocument as on 1 August 2007

33 Parker, T, Gross, O, Rivkin, D (2005) 'The Torture Question: Is Torture Ever Justified?', Frontline, 18 October: http://www.pbs.org/wgbh/pages/frontline/torture/justify/3.html as on 25 July 2007

34 United Nations (2006) Madrid, Spain, 7 September 2006 - Secretary-General's press conference with Spanish Prime Minister Jose Luis Rodriguez Zapatero (unofficial transcript), 7 September: http://www.un.org/apps/sg/offthecuff.asp?nid=937 as on 15 June 2007

\section{Chapter 2}

1 Commonwealth Secretariat (2005) International Human Rights Day: Message by Commonwealth Secretary-General Don McKinnon, Press Release, 10 December: http://www.genderandtrade.org/press/31555/34582/147750/international_human_rights_day_10_december_2005.htm as on 25 July 2007

2 United Nations Security Council (2001) Resolution 1368, 12 September: http://daccessdds.un.org/doc/UNDOC/GEN/N01/533/82/PDF/N0153382.pdf?OpenElement as on 22 June 2007

3 United Nations Security Council (2001) Resolution 1373, 28 September: http://www.unodc.org/images/resolution\%201373.pdf as on 22 June 2007. For a discussion of other anti-terrorism resolutions adopted since 2001 see Saul, B (2005) 'Definition of "Terrorism" in the UN Security Council: 1985-2004', Chinese Journal of International Law, Vol. 4, No. 1, pp. 141-166, p. 161

4 United Nations Security Council (2003) Resolution 1456, 20 January: www.unhchr.ch/Huridocda/Huridoca.nsf/(Symbol)/S.RES.1456+(2003).En? Opendocument as on 22 June 2007

5 United Nations General Assembly (2006) UN Global Counter-Terrorism Strategy and corresponding Plan of Action: http://www.un.org/terrorism/strategycounter-terrorism.html as on 4 June 2007

6 For progress on the work of the Ad Hoc Committee see United Nations (1996) Ad Hoc Committee Established by General Assembly Resolution 51/210 of 17 December 1996: http://www.un.org/law/terrorism/index.html as on 15 July 2007. See also the report of the UN Sixth Committee Working Gireutoto assist 
in the mandate: United Nations Office on Drugs and Crime (2006) General Assembly: Sixth Committee Summary Record of the $21^{\text {st }}$ Meeting, UN Doc A/C.6/61/SR.21, 27 November: http://domino.un.org/UNISPAL.NSF/eed216406b50bf6485256ce10072f637/012c19e8b3e74bd3852572c3006f8db7! OpenDocument as on 21 June 2007

7 Council of Europe (2005) Convention on the Prevention of Terrorism (signed by Cyprus, Malta and the UK): http://conventions.coe.int/Treaty/EN/Treaties/Html/196.htm; Organization of African Unity (1999) Convention on the Prevention and Combating of Terrorism (ratified by Ghana, Kenya, Lesotho, Malawi, Mozambique, Mauritius, Nigeria, South Africa, Seychelles, Tanzania and Uganda): http://www.africa-union.org/root/AU/Documents/Treaties/Text/Algiers_convention\%20on\%20Terrorism.pdf; Organization of American States (2002) Inter-American Convention Against Terrorism (ratified by Antigua and Barbuda, Canada and Domenica): http://www.oas.org/ xxxiiga/english/docs_en/docs_items/AGres1840_02.htm as on 22 July 2007

8 'Each Party shall take appropriate measures, particularly in the field of training of law enforcement authorities and other bodies, and in the fields of education, culture, information, media and public awareness raising, with a view to preventing terrorist offences and their negative effects while respecting human rights obligations as set forth in, where applicable to that Party, the Convention for the Protection of Human Rights and Fundamental Freedoms, the International Covenant on Civil and Political Rights, and other obligations under international law.': Article 3(1), Council of Europe (2005) Convention on the Prevention of Terrorism: http://conventions.coe.int/Treaty/EN/Treaties/Html/196.htm as on 22 July 2007

9 The African Convention gives a very broad definition: "'Terrorist act" means: (a) any act which is a violation of the criminal laws of a State Party and which may endanger the life, physical integrity or freedom of or cause serious injury or death to, any person, any number or group of persons or causes or may cause damage to public or private property, natural resources... and is calculated or intended to...': Article 1(3)(b), Organization of African Unity (1999) Convention on the Prevention and Combating of Terrorism: http://www.africa union.org/root/AU/Documents/Treaties/Text/Algiers_convention\%20on\%20Terrorism.pdf as on 22 July 2007

10 The Pacific nations of Kiribati, Samoa, Solomon Islands, Tuvalu and Vanuatu are not members of Interpol.

11 Known together as the "Fusion Task Force" made up of Project Pacific (Southeast Asia), Project Kalkan (Central Asia), Project Amazon (South America) and Project Baobab (Africa): Interpol (2007) Fusion Task Force: Operational Investigative Support: http://www.interpol.int/Public/FusionTaskForce/default.asp as on 14 June 2007

12 The Southern African Regional Police Chiefs Co-operation Organisation was formed in 1996.

13 'In the performance of all their duties, police officials shall respect and protect human dignity and maintain and uphold all human rights for all persons': Article 1, Southern African Regional Police Chiefs Co-operation Organisation, Code of Conduct:

www.amnesty.ie/.../youth\%20and\%20students/Southern\%20African\%20Regional\%20Police\%20Chiefs\%20Co.pdf as on27 June 2007

14 Australian Institute of Police Management (2007) 'Leadership in Counter Terrorism Program (LinCT)', Australian Institute of Police Management Website: http://www.aipm.gov.au/linct.html as on 15 July 2007

15 Tyson, A S (2005) 'U.S. Pushes Anti-Terrorism in Africa', Washington Post, 26 July: www.washingtonpost.com/wp-dyn/content/article/2005/07/25/AR2005072501801.html as on 15 June 2007

16 Office of United Nations Commission for Human Rights (2005), Resolution 2005/80, E/CN/4/RES/2005/80, 25 January: http://daccessdds.un.org/doc/UNDOC/GEN/G05/104/91/PDF/G0510491.pdf?OpenElement as on 22 July 2007

17 Article 4, Office of the United Nations High Commissioner of Human Rights (1966) International Covenant on Civil and Political Rights: http://www.ohchr.org/english/law/ccpr.htm as on 22 July 2007. These derogable rights are contained respectively in Articles 19(2), 22, 21, and 17 of the ICCPR

18 UN Human Rights Committee (2001) General Comment No 29 States of Emergency (Article 4), UN Doc CCPR/C/21/Rev.1/Add.11, 31 August: http://www.unhchr.ch/tbs/doc.nsf/0/71eba4be3974b4f7c1256ae200517361?Opendocument as on 22 July 2007

19 UN Human Rights Committee (2001) General Comment No 29 States of Emergency (Article 4), UN Doc CCPR/C/21/Rev.1/Add.11, 31 August: http://www.unhchr.ch/tbs/doc.nsf/0/71eba4be3974b4f7c1256ae200517361?Opendocument as on 22 July 2007

20 These non-derogable rights are contained respectively in Articles 6, 7, 8, 11, 15, 16 and 18, Office of the United Nations High Commissioner of Human Rights (1966) International Covenant on Civil and Political Rights: http://www.ohchr.org/english/law/ccpr.htm as on 22 July 2007

21 UN Human Rights Committee (2001) General Comment No 29 States of Emergency (Article 4), UN Doc CCPR/C/21/Rev.1/Add.11, 31 August: http://www.unhchr.ch/tbs/doc.nsf/0/71eba4be3974b4f7c1256ae200517361?Opendocument as on 22 July 2007

22 McKinnon, D (2005) International Human Rights Day, 10 December 2005: Message, Press Release, 9 December: http://www.thecommonwealth.org/press/34582/147750/international_human_rights_day_10_december_2005.htm as on 15 June 2007.

23 Article 62, African Union (1981) African (Banjul) Charter on Human and Peoples' Rights: www.hrcr.org/docs/Banjul/afrhr.html as on 22 July 2007

24 Article 7, Organisation of American States (1985) Inter-American Convention to Prohibit and Prevent Torture: www.oas.org/juridico/English/Treaties/a-51.html as on 22 July 2007

25 See Council of Europe Committee of Ministers (2001) Recommendation Rec (2001) 10 on the European Code of Police Ethics: http://www.legislationline.org/legislation.php?tid=155\&lid=4886 as on 15 July 2007

26 United Nations General Assembly (1979) Resolution 34/169 Code of Conduct for Law Enforcement Officials, 17 December: htth. fowww.un.org/documents/ga/res/34/a34res169.pdf as on 22 July 2007 
27 Article 2, United Nations General Assembly (1979) Resolution 34/169 Code of Conduct for Law Enforcement Officials, 17 December: http://www.un.org/documents/ga/res/34/a34res169.pdf as on 22 July 2007

28 Article 2, United Nations General Assembly (1979) Resolution 34/169 Code of Conduct for Law Enforcement Officials, 17 December: http://www.un.org/documents/ga/res/34/a34res169.pdf as on 22 July 2007

29 Office of the United Nations High Commissioner for Human Rights (1997) Human Rights and Law Enforcement: A Manual on Human Rights Training for the Police, UN Doc HR/P/PT/5: http://www.unhchr.ch/html/menu6/2/train5add2.pdf as on 22 June 2007; Office of the United Nations High Commissioner for Human Rights (2002) Human Rights and Law Enforcement: A Trainer's Guide on Human Rights for the Police, UN Doc HR/P/PT/5/Add.2: 3http://www.ohchr.org/english/about/publications/docs/train5add2.pdf as on 5 July 2007; Office of the United Nations High Commissioner for Human Rights, International Human Rights Standards for Law Enforcement: A Pocket Book on Human Rights for the Police: www.ohchr.org/english/about/publications/docs/pocketbook.pdf as on 5 July 2007.

30 Article 9, Office of the United Nations High Commissioner for Human Rights (1966) International Covenant on Civil and Political Rights: http://www.ohchr.org/english/law/ccpr.htm as on 22 July 2007

31 United Nations Human Rights Committee (2001) General Comment No 29: States of Emergency (Article 4), UN Doc CCPR/C/21/Rev1/Add11: http://www.unhcr.ch/tbs/doc.nsf as on 22 July 2007

32 United Nations Human Rights Committee (2001) General Comment No 29: States of Emergency (Article 4), UN Doc CCPR/C/21/Rev1/Add11: http://www.unhcr.ch/tbs/doc.nsf. as on 22 July 2007

It is also codified in Article 9(4), Office of the United Nations High Commissioner for Human Rights (1966) International Covenant on Civil and Political Rights: http://www.ohchr.org/english/law/ccpr.htm as on 22 July 2007

33 The UN Human Rights Committee described the right to life as "the supreme right": United Nations Human Rights Committee (1982) General Comment No. 1 on Article 6, UN Doc A/37/40: http://www.unhchr.ch/tbs/doc.nsf/0/84ab9690ccd81fc7c12563ed0046fae3?Opendocument as on 22 July 2007. The UDHR (Article 3) and the ICCPR (Article 9(1)) state that "Everyone has the right to life liberty and security of the person".

34 United Nations Human Rights Committee (1982) General Comment No. 1 on Article 6, UN Doc A/37/40: http://www.unhchr.ch/tbs/doc.nsf/0/84ab9690ccd81fc7c12563ed0046fae3?Opendocument as on 22 July 2007

35 This formulation is contained in the United Nations High Commissioner for Human Rights (1997) Human Rights and Law Enforcement: A Manual on Human Rights Training for the Police, UN Doc HR/P/PT/5: http://www.unhchr.ch/html/menu6/2/train5add2.pdf as on 22 June 2007. It derives its standards from the principles in the UN Code of Conduct and the UN Basic Principles on the Use of Force and Firearms

36 Article 3, United Nations General Assembly (1979) Resolution 34/169 Code of Conduct for Law Enforcement Officials, 17 December: http://www.un.org/documents/ga/res/34/a34res169.pdf as on 22 June 2007

37 European Court of Human Rights (1995) McCann v United Kingdom 21 EHRR 97:

http://sim.law.uu.nl/SIM/CaseLaw/hof.nsf/0/c959f053662c3ec4c1256640004c2d90?OpenDocument as on 1 August 2007. See also Principle 9, United Nations (1990) Basic Principles on the Use of Force and Firearms by Law Enforcement Officials:

http://www.ohchr.org/english/law/firearms.htm as on 22 July 2007

38 European Court of Human Rights (1995) McCann v United Kingdom 21 EHRR 97: http://sim.law.uu.nl/SIM/CaseLaw/hof.nsf/0/c959f053662c3ec4c1256640004c2d90?OpenDocument as on 1 August 2007

39 See for example European Court of Human Rights in (1995) McCann v United Kingdom 21 EHRR 97; (1994) Taylor v United Kingdom 79-A DR 127; (2000) Salman v Turkey 34 EHRR 425; (2001) Jordan v United Kingdom 37 EHRR 52

40 Principle 9, United Nations (1990) Basic Principles on the Use of Force and Firearms by Law Enforcement Officials: http://www.ohchr.org/english/law/firearms.htm as on 22 July 2007

41 Principle 9, United Nations (1990) Basic Principles on the Use of Force and Firearms by Law Enforcement Officials: http://www.ohchr.org/english/law/firearms.htm as on 22 July 2007

42 Principle 20, United Nations (1990) Basic Principles on the Use of Force and Firearms by Law Enforcement Officials: http://www.ohchr.org/english/law/firearms.htm43 Commonwealth Law Ministers (2002) Communiqué of the Law Ministers' Meeting Kingstown, St Vincent \& the Grenadines, p.1:

http://www.thecommonwealth.org/shared_asp_files/uploadedfiles/\%7B848FB421-E170-4071-A19D-BB3B5CDDEA50\%7D_Final\%20 Communique.pdf as on 26 June 2007

43 Commonwealth Law Ministers (2002) Communiqué of the Law Ministers' Meeting Kingstown, St Vincent \& the Grenadines, p.1: http://www.thecommonwealth.org/shared_asp_files/uploadedfiles/\%7B848FB421-E170-4071-A19D-

BB3B5CDDEA50\%7D_Final\%20Communique.pdf as on 26 June 2007

44 Commonwealth Secretariat Human Rights Unit (2007) Increasing Knowledge and Awareness: Human Rights Training for Police Trainers in the Commonwealth: http://www.thecommonwealth.org/Internal/39419/153663/increasing_knowledge_and_awareness/as on 20 July 2007

45 Commonwealth Secretariat (2006) Commonwealth Manual on Human Rights Training for Police Training, p. 171: www.thecommonwealth.org/Templates/Internal.asp?NodeID=152764 as on 22 June 2007

46 Commonwealth Secretariat (2006) Commonwealth Manual on Human Rights Training for Police Training, p. 172: www.thecommonwealth.org/Templates/Internal.asp?NodeID=152764 as on 22 June 2007 
47 See Commonwealth Human Rights Initiative (2005) Sample Letter of Support for the creation of a Commonwealth Expert Group on Policing : http://www.humanrightsinitiative.org/programs/aj/police/sample_letter_support_for_expert_grp_on_policing.doc as on 22 July 2007

48 Para 32, Commonwealth Secretariat (2005) Final Communiqué: Commonwealth Heads of Government Meeting, Malta 25-27 November: http://www.thecommonwealth.org/shared_asp_files/uploadedfiles/\%7B848FB421-E170-4071-A19D-BB3B5CDDEA50\%7D_Final\% 20Communique.pdf as on 26 June 2007

Chapter 3

1 Malta and Cyprus apply the European Union Framework Decision on Combating Terrorism (OJL 16422.06 .2002 p.3)

2 Internal Security Act, 1965 (Singapore); Internal Security Act, 1960 (Malaysia); Internal Security Act, 1984 (Brunei Darussalam)

3 International Freedom of Expression Exchange (2005) Botswana: Misa Slams 'Draconian'Security Law: http://www.ifex.org/en/content/view/full/66242/ as on 8 January 2007

4 Section 83.3, Criminal Code, 1985 (Canada); and Section 114, Immigration Act, 1987 (New Zealand), followed by the Immigration Amendment Act, 1999 (New Zealand)

5 Section 6, [1]-[10], Supreme Court of Canada (2007) Charkaoui v Canada, SCC 9, 23 February: http://scc.lexum.umontreal.ca/en/2007/2007scc9/2007scc9.html as on 29 June 2007

6 Section 9, Supreme Court of Canada (2007) Charkaoui v Canada, SCC 9, 23 February: http://scc.lexum.umontreal.ca/en/2007/2007scc9/2007scc9.html as on $29 \mathrm{June} 2007$

7 See Mayeda, A (2007) 'Top court annuls anti-terror measure', The Gazette, 23 February: http://www.canada.com/montrealgazette/news/story.html?id=b26cd090-c9d9-4a97-a773-e870614864b4\&k=22056 as on 13 April 2007

8 Section 72,(Persons Threatening National Security), Immigration Act, 1987 (New Zealand)

9 New Zealand Court of Appeal (2004), Ahmed Zaoui v Attorney General, CA 166/04, 17 September

10 New Zealand Supreme Court (2005), Attorney-General v Ahmed Zaoui \&Ors, NZSC 38, 21 June

11 See also Amnesty International New Zealand Section (2007) Ahmed Zaoui Timeline of Events, http://www.amnesty.org.nz/web/pages/home.nsf/dd5cab6801f1723585256474005327c8/04d345f73f3d0469cc257321001b4e9c!OpenDocument as on 27 July 2007

12 This information is taken from the country reports submitted to the UN Counter Terrorism Committee: http://www.un.org/sc/ctc/countryreports.shtml

13 House of Lords (UK) (2004) A (FC) and others (FC) (Appellants) v. Secretary of State for the Home Department (Respondent), 16 December, http://www.publications.parliament.uk/pa/ld200405/ldjudgmt/jd041216/a\&oth-1.htm as on 23 July 2007

14 Lord Carlile (2007) Lord Carlile Report: Control Orders are "Necessary" and "Justifiable”", 19 February: http://security.homeoffice.gov.uk/newspublications/news-speeches/Lord-carlile-report as on 16 April 2007; (2007) 'Terror suspects put on control orders should be prosecuted', The Independent, 20 February: http://news.independent.co.uk/uk/politics/article2287031.ece as on18 April 2007; (2007) 'Liberty rejects the Home Secretary's blustering rhetoric on control orders', Liberty, 24 May: http://www.liberty-human-rights.org.uk/news-and-events/1-press-releases/2007/control-orderresponse.shtml as on 6 June 2007

15 Court of Appeal (UK) (2006), SSHD vJJ \& Ors, EWCACiv 1141, as reported in The Times on the 18 August 2006

16 (2003) 'Bali death toll set at 202', BBC News, http://news.bbc.co.uk/1/hi/world/asia-pacific/2778923.stm as on 11 July 2007

17 Anti-Terrorism Act, 2001 (Antigua \& Barbuda). This law was later repealed by the Prevention of Terrorism Act, 2005.

18 Section 2, Prevention of Terrorism Act, 2005 (Antigua \& Barbuda). Similar provisions are found in the definitions of Trinidad \& Tobago's Anti-Terrorism Act, 2004

19 Act 11, Anti Money Laundering Act, 2004 (Nauru); Act 14, Counter Terrorism \& Transnational Organised Crime Act, 2004 (Nauru)

20 Current members of the FATF are Argentina, Australia, Austria, Belgium, Brazil, Canada, Denmark, European Commission, Finland, France, Germany, Greece, Gulf Co-operation Council, Hong Kong China, Iceland, Ireland, Italy, Japan, Luxembourg, Mexico, the Netherlands, New Zealand, Norway, Portugal, Russian Federation, Singapore, South Africa, Spain, Sweden, Switzerland, Turkey, United Kingdom and the United States

21 Financial Action Task Force (2006), Annual Review of Non-Cooperative Countries and Territories 2005-2006, June, p.5: http://www.fatfgafi.org/dataoecd/0/0/37029619.pdf as on 22 June 2007. Regional bodies like the FATF have also emerged to promote FATF standards. These include the Asia Pacific Group, Caribbean Financial Action Task Force (CFATF), and Eastern and Southern Africa Anti-Money Laundering Group (ESAAMLG)

22 Interpol (2007) South African police join international security effort at Cricket World Cup, https://www.interpol.int/Public/News/2007/CricketWorldCup20070406.asp, as on 30 July 2007 
23 US Department of State (2007), Kenya: Security Assistance, www.state.gov/t/pm/64672.htm as on 7 July 2007; United Nations Press Service (2007), UN meeting to focus on strengthening counter-terrorism efforts in West Africa, Press Release, 10 July

24 Section 83.231, Public Safety Act, 2002 (Canada)

25 Section 3, Anti-Terrorism Act 2004 (The Bahamas); Section 289-295, Penal Code (The Bahamas)

26 Dyer, C (2005) 'MP's demand reforms of special advocate system', The Guardian, 4 April, http://politics.guardian.co.uk/attacks/story/0,,1451564,00.html as on 24 July 2007

27 An exception is the International Terrorism (Emergency Powers) Act, 1987 (New Zealand); Section 16 of this Act provides police with "protection from liability". The New Zealand Law Commission and the Advisory Council of Jurists have recommended that this Act be repealed.

28 See Advisory Council of Jurists (2004) Asia Pacific Forum of National Human Rights Institutions, Final Report on the Reference on the Rule of Law in Combating Terrorism, Kathmandu, p. 117.

29 See Smith, JE (2003) New Zealand's Anti-Terrorism Campaign: Balancing Civil Liberties, National Security, and International Responsibilities, Wellington, p. 26.

30 See Privacy International (2004) Terrorism Profile-South Africa, http://www.privacyinternational.org/article.shtml?cmd\%5B347\%5D=x-347-66677\#_ftn1, as on 30 July 2007

31 Protection of Constitutional Democracyagainst Terrorism and Related Activities Act, 2004 (South Africa)

32 The Terrorist and Disruptive Activities Act, 1985 (India); Prevention of Terrorism Act, 2002 (India)

33 Unlawful Activities Prevention (Amendment) Act, 2004 (India)

34 Section 83.30 and others, Criminal Code, 1985 (Canada) as modified by the Anti-Terrorism Act, 2001 (Canada)

35 Scheinin, M (2005) Promotion and Protection of Human Rights: Report of the Special Rapporteur on the promotion and protection of human rights and fundamental freedoms while countering terrorism, E/CN.4/2006/98, 28 December:

http://daccessdds.un.org/doc/UNDOC/GEN/G05/168/84/PDF/G0516884.pdf?OpenElement as on 30 July 2007

Section 2(1)(b), Terrorism Act, 2003 (Grenada); Part 5.3, Section 101.1, Criminal Code Act, 1995 (Australia), as amended in 2005

Prevention and Suppression of Terrorism Act, 2002 (Samoa)

38 Section 2, Prevention of Terrorism Act, 2004 (Seychelles)

39 Section 1, Commonwealth Secretariat (2002) Explanatory Guide to the Model Legislative Provisions on Measures to Counter Terrorism, September: http://www.thecommonwealth.org/shared_asp_files/uploadedfiles/\%7B32AF830D-F83A-4432-8051-750C789531A5\%7D_final_terrorism_law.pdf as on 27 June 2007

40 The Commonwealth Committee on Terrorism recommended that "the Commonwealth Secretariat could prepare model legislation and guidelines for member countries to use as a basis for the development of domestic implementing legislation and associated measures": Para 7, Commonwealth Heads of Government Meeting (2002) Coolum Communique: http://thecommonwealth.org/Internal/33374/36310/36315/coolum_communique/as on 22 June 2007.

41 The expert group stated that "it is for each country to decide upon the sensitive and complex policy considerations [when adopting] a legislative provision appropriate for that country": Clause 1, Commonwealth Secretariat (2002) Explanatory Guide to the Model Legislative Provisions on Measures to Counter Terrorism, September: http://www.thecommonwealth.org/shared_asp_files/uploadedfiles/\%7B32AF830D-F83A-4432-8051750C789531A5\%7D_final_terrorism_law.pdf as on 27 June 2007.

42 Prevention of Terrorism Act, 2001 (Antigua and Barbuda); Counter Terrorism and Transnational Organised Crime Act, 2005 (Vanuatu); Penal Code (Amendment) Act, 2003 (Vanuatu); United Nation (Anti-Terrorism Measures) Regulations, 2001(Singapore); Prevention of Terrorism Act, 2004 (Seychelles); Extradition Act, 2003 (Kiribati); Financial Transactions Reporting Act, 2004 (Fiji); Anti Terrorism Bill, 2006 (Kenya); Prevention of Terrorism Act, 2002 (Tanzania)

43 Section 2(c), Prevention of Terrorism Act, 1990 (Maldives)

44 Section 2, Internal Security Act, 1960 (Malaysia).

45 Section 28, Terrorism Act, 2000 (UK).

46 Section 6, Anti-terrorism Ordinance, 1999 modifying the Anti-Terrorism Act, 1997(Pakistan)

47 Section 6, Anti-Terrorism Act, 1997 (Pakistan) requires that the 'use of threat is designed to coerce and intimidate or overawe the government or the public or a section of the public or community or sect or create a sense of fear or insecurity in society'.

48 Kaliopi K K (1997) Terrorism and human rights: Working paper submitted by Ms. Kalliopi K. Koufa in accordance with Sub-Commission resolution 1996/20, E/CN.4.Sub.2/1997/28, 26 June, pp.448-467: http://www.hri.ca/fortherecord1997/documentation/subcommission/e-cn4-sub2-1997-28.htm as on 15 June 2007 
49 Section 9(2), Anti Terrorism Act, 2002 (Uganda); See also Committee to Protect Journalists (2002) Attacks on the Press in 2002: http://www.cpj.org/attacks02/africa02/uganda.html as on 14 June 2007

50 Section 73(1)(b), Internal Security Act, 1960 (Malaysia)

51 Human Rights Watch (2002) Malaysia's Internal Security Act and Suppression of Political Dissent: http://hrw.org/backgrounder/asia/malaysia-bck-0513.htm as on 30 March 2007

52 Buttler, M, Anderson, P (2007) 'Cop That: Four months after G20 protests halted a city, anti-terror police swoop in raids' Herald Sun, 15 March 2007; Marr, D (2007) 'Faith in the Demo Marching out the Door', The Age, 2 June: www.theage.com.au/news/in-depth/faith-in-the-demo-marching-out-thedoor/2007/06/01/1180205502591.html as on 15 June 2007

53 See Marr, D (2007) 'Faith in the Demo Marching out the Door', The Age, 2 June: http://www.theage.com.au/news/in-depth/faith-in-the-demo-marching-out-the-door/2007/06/01/1180205502591.html; Buttler, M, Anderson, P (2007) 'Cop That: Four months after G20 protests halted a city, anti-terror police swoop in raids', Herald Sun, 15 March, p 1. as on 21 July 2007

54 National Council of Resistance of Iran (2007) European Council is not above the law, 2 February: http://www.ncr-iran.org/content/view/2832/70/ as on 20 June 2007; National Council of Resistance of Iran (2007) EU's Ministers of Economic and Financial Affairs' Council violates the verdict by the European Court, 1 February: http://www.ncr-iran.org/content/view/2831/69/as on 20 June 2007

55 Emergency (Prevention and Prohibition of Terrorism and Specified Terrorist Activities) Regulations, 2006 (Sri Lanka). See the case of freelance journalist Parameswaree Maunasámi writing on the separatist conflict, who was arrested under the Prevention of Terrorism Act, 1979 (Sri Lanka); Committee to Protect Journalists (2006) Sri Lanka: Freelance Tamil Journalist Arrested, 30 November: http://www.cpj.org/news/2006/asia/sri30nov06na.html as on 25 June 2007

56 UN Special Rapporteur Kaliopi K. Koufa (2004) Specific human rights issues: new priorities, in particular Terrorism and counter-terrorism; Terrorism and human rights, Final report to the $56^{\text {th }}$ session of the Sub-Commission on the Promotion and Protection of Human Rights, Conclusion and Recommendation, 25 June, E/CN.4/Sub.2/2004/40

\section{Chapter 4}

1 Section 46, Unlawful Activities Prevention Amendment Act, 2004 (India)

2 Safeguards under Section 5, Indian Telegraph Act, 1885 (India) have been overridden by provisions included in the current anti-terrorism legislation

3 Section 46, Unlawful Activities Prevention Amendment Act, 2004 (India); See International Federation of Journalists (2005), Courage and Censorship: Journalists and Press Freedom in South Asia 2004-2005: http://www.ifj-asia.org/files/ifj_sa_press_freedom_report_overview.pdf as on 12 July 2007

4 See Surveillance Studies Network (2006) A Report on the Surveillance Society, September: http://www.ico.gov.uk/upload/documents/library/data_protection/practical_application/surveillance_society_full_report_2006.pdf as on 23 July 2007

5 Surveillance Studies Network (2006) A Report on the Surveillance Society, September: http://www.ico.gov.uk/upload/documents/library/data_protection/practical_application/surveillance_society_full_report_2006.pdf as on 23 July 2007

6 (2007) 'Stop and search 'overused and ineffective", Politics.co.uk, 23 March http://www.politics.co.uk/news/bills/organised-crime-bill/stop-and-searchoverused-and-ineffective- $\$ 469255$. htm as on 30 July 2007

7 NSW Ombudsman (2007) Issues Paper: Review of Parts 2A and 3 of the Terrorism (Police Powers) Act 2002,p.2: http://www.ombo.nsw.gov.au/publication/PDF/discussion/terrorism\%20issues\%20paper\%20april07.pdf as on 24 July 2007

8 Section 45(1)(b), Terrorism Act, $2000(\mathrm{UK})$

9 Stone, Richard (2006) 'Police powers and human rights in the context of terrorism', Managerial Law, Vol. 48, No. 4, pp. 384-399, Barmarick Publications, p.390.

10 Sections 44 and 45(1)(a), Terrorism Act, 2000 (UK); See also House of Commons (2004) Memorandum submitted by the Mayor of London: www.publications.parliament.uk/pa/cm200405/cmselect/cmhaff/165ii/165we23.htm as on 24 July 2007

11 In March 2007 the Liberal Democrats criticised stop and search powers highlighting that out of over 167,000 people stopped under anti-terrorism laws there have been only 40 convictions: (2007) 'Campbell attacks stop-and-search', BBC News, 23 March: http://news.bbc.co.uk/1/hi/uk_politics/6482263.stm as on 30 July 2007

12 (2005) 'Muslim face increased stop and search', The Guardian, March 2: http://www.guardian.co.uk/guardianpolitics/story/0,,1428387,00.html as on May 92007; see also Kundani, A(2006) UK: Racial Profiling and anti-terror stop and search, 3 February: http://realcostofprisons.org/blog/archives/2006/02/uk_racial_profi.html as on 20 April 2007

13 Blagg, H., Morgan, N., Cunneen, C \& Ferrante, A., 'Systemic Racism as a Factor in the Overrepresentation of Aboriginal People in the Victorian Criminal Justice System' in Tonry, M. (ed) (2005) Ethnicity, Crime and Immigration: Comparative and Cross-National Perspectives, Crime and Justice, Vol. 21, University of Chicago, Chicago, September.

14 (2007). 'Stop and Search Powers Damaging', BBC News, 31 May: http://news.bbc.co/uk/go/pr/-/2/hi/uk_news/england/london/6706885.stm as on 14 Gere 2007

66 
15 Sheinin, M (2007) Implementation of General Assembly Resolution 60/251 of 15 March 2006 Entitled "Human Rights Council, A/HRC/4/26, 29 January, p.7

16 Para 4, Commonwealth Secretariat (1991) Commonwealth Harare Declaration: www.thecommonwealth.org/Internal/20723/34457/harare_commonwealth_declaration/as on 21 July 2007

17 See Amnesty International (2005) Kenya: The impact of “anti-terrorism” operations on human rights, 23 March, p.3: http://web.amnesty.org/library/index/engafr320022005 as on 2 April 2007

18 Human Rights Watch (2007) People Fleeing Somalia War Secretly Detained,31 March: http://www.alertnet.org/thenews/newsdesk/HRW/9b0b6c93373636cd0475c7d6e6a23723.htm as on 12 July 2007; Amnesty International (2007) Amnesty Ethiopia: Incommunicado detention/fear of torture or ill-treatment/health concern, 16 April: http://web.amnesty.org/library/Index/ENGAFR250052007 as on 12 July 2007 Section 29, Prevention of Terrorism Act, 2002 (Tanzania) Section IV, Prevention of Terrorism Act, 2002 (India)

21 The Special courts introduced under POTA granted discretion to conduct trials in private places. Trial records were allowed to be kept from the public, dismissing the right to information and denying independent monitoring of the judicial process: Mehta, Sachin (2004) 'Repeal of POTA: Justified', Legal Service India:

http://www.legalservicesindia.com/articles/pota.htm as on 11 July 2007

22 (2003) '12 yr-old boy arrested under POTA', The Times of India, 20 February: http://timesofindia.indiatimes.com/articleshow/38009357.cms as on 23 July 2007

23 Bhelari, K (2003) 'Catch 'em young', The Week, 16 March. The Maoist Communist Centre is a Naxalite organisation and is listed as a terrorist organisation. There is much activity in the Jharkhand region.

24 Asian Centre for Human Rights (2003) Appeal for Complaint for enforcement of Juvenile Justice (Care and Protection) Act, 2000 with regard to 14 -year-old Ms Mayanti Raj Kumari of Pandrani village, 7 October: Bhelari, K (2003) 'Catch 'em young', The Week, 16 March

25 People's Union for Civil Liberties (2003) In Jharkhand all the laws of the land are replaced by POTA, February: http://www.pucl.org/Topics/Law/2003/poto-jharkhand.htm as on 23 July 2007

26 Supreme Court of India (1997) DK Basu vs. State of West Bengal, 1 SC 1 (India)

27 Supreme Court of India (1997) DK Basu vs. State of West Bengal, 1 SC 1 (India)

28 See Gossett, S (2005) 'Report Warns of Terrorists' 'Great Ramadan Offensive" in Cyberspace News Service, 8 September: Bhelari, K (2003) 'Catch 'em young', The Week, 16 March as on 30 March 2007

29 See Amnesty International (2006) Asia-Pacific:India, http://web.amnesty.org/report2006/ind-summary-eng as on 2 April 2007

30 Human Rights Watch (2007) Pakistan Country Summary, January: hrw.org/wr2k7/pdfs/pakistan.pdf as on 8 April 2007.

31 See Amnesty International (2006) Asia-Pacific:India, http://web.amnesty.org/report2006/ind-summary-eng as on 2 April 2007

32 Amnesty International et al (2007) Off the Record: US Responsibility for Enforced Disappearances in the "War on Terror", 7 June: http://web.amnesty.org/library/Index/ENGAMR510932007 as on 23 July 2007.

33 Sections 34ZO, 34ZP and 34ZQ, Australian Security Intelligence Organisation Act, 1979 (Australia) (as amended by ASIO Amendment (Terrorism) Act 2003); See Article 14(3)(b), Office of the United Nations High Commissioner for Human Rights (1966) International Covenant on Civil and Political Rights: http://www.ohchr.org/English/law/ccpr.htm:: "In the determination of any criminal charge against him, everyone shall be entitled to the following minimum guarantees, in full equality... To have adequate time and facilities for the preparation of his defence and to communicate with counsel of his own choosing".

34 United Nations Human Rights Committee (1990), Van Alphen v The Netherlands, UN Doc CCPR/C/39/D/305/1988: http://hei.unige.ch/ clapham/hrdoc/docs/HRC305-1988.htm as on 22 July 2007.

35 Section 3(2), Special Powers Act, 1974 (Bangladesh); Section 4, Fundamental Rights and Freedoms Decree, 2000 (Fiji); Preventative Detention Act, 1962 (Tanzania)

36 Internal Security Act, 1960 (Malaysia); Internal Security Act, 1965 (Singapore)

37 (2005) 'Blair defeated over terror laws', BBCNews, 9 November: http://news.bbc.co.uk/1/hi/uk_politics/4422086.stmas on 14 June 2007

38 (2007) 'Reid to unveil anti-terror plans', BBC News, 7 June: http://news.bbc.co.uk/1/hi/uk_politics/6727267.stm as on 8 June 2007

39 Part 4, Anti-Terrorism Crime and Security Act, 2001 (UK)

40 Barder, B (2005) 'Commentary on 'Freed, but why?', The Guardian, 8 February: http://www.barder.com/politics/liberty/crelease/guardian.php as on 2 April 2007 
41 Verkaik, R (2005) 'Release of terror suspect increases pressure on Clarke', The Independent, 2 February: findarticles.com/p/articles/mi_qn4158/is_20050202/ai_n9498825 as on 11 July 2007

42 Sections 34ZO, 34ZP and 34ZQ, Australian Security Intelligence Organisation Act, 1979 (Australia

43 Presently in Australia, decisions made by executive under the ASIO Act, the Telecommunications (Interception) Act, 1979 and the decision to issue a preventive detention order are all excluded from review under the Administrative Decisions (Judicial Review) Act, 1977 (Australia)

44 Section 41, Criminal Law (Temporary Provisions) Act, 1958 (Singapore) Also see Article 9 (4), Office of the United Nations High Commissioner of Human Rights (1966) International Covenant on Civil and Political Rights: http://www.ohchr.org/english/law/ccpr.htm as on 27 June 2007

45 Sections 23 (4), 23 (6), 23 (8), 23DA, Anti-Terrorism Act, 2004 (Australia); See Nicholson, B (2007) 'After the Arrests: What Happens Now', The Age, 4 July: http://www.theage.com.au/news/national/after-the-arrests-what-happens-now/2007/07/03/1183351212554.html as on 12 July 2007

46 Division 3, Part III, Australian Security Intelligence Organisation Act, 1979 (Australia) (as amended by ASIO Amendment (Terrorism) Act 2003)

47 See Eminent Jurists Panel on Terrorism, Counter-Terrorism and Human Rights (2006) Eminent Jurists Panel Concludes Australia Hearing on CounterTerrorism Laws, Practices and Policies, Press Release, 17 March: http://ejp.icj.org/IMG/press_release_final.pdf as on 7 July 2007

48 Scheinin, M (2006) 'Australia: study on human rights compliance while countering terrorism' in Implementation of General Assembly Resolution 60/251 of 15 March 2006 Entitled "Human Rights Council”", a/hrc/4/26/Add.2, 14 December, p.18:

http://www.ohchr.org/pacific/docs/AustraliaA.HRC.4.26.Add.3.pdf as on 5 July 2007; Eminent Jurists Panel on Terrorism, Counter-Terrorism and Human Rights (2006) Eminent Jurists Panel Concludes Australia Hearing on Counter-Terrorism Laws, Practices and Policies, Press Release, 17 March: http://ejp.icj.org/IMG/press_release_final.pdf as on 7 July 2007

49 Inter-American Court of Human Rights (1988) Velasquez Rodriguez Case, Case 9799 (Peru)

50 Catholic Information Service for Africa (2007) 'Muslims Protest Expulsion of Cleric Linked to Terrorism', All Africa, 8 May: http://allafrica.com/stories/200705080793.html as on 15 May 2007.

51 Millicent, J (2007) 'Ibrahim Mohamed faces deportation', Kenyan Broadcasting Corporation, 28 April: http://www.kbc.co.ke/story.asp?ID=42313 as on 15 May 2007.

52 Mango, C (2007) 'Police Arrest 11 Terror Suspects', All Africa, 16 April: http://allafrica.com/stories/200704251224.html as on 15 May 2007

53 Section 56, Internal Security Act, 1984 (Brunei Darussalam); Section 74 \& 17, Internal Security Act, 1960 (Malaysia); Section 75, Internal Security Act, 1963 (Singapore)

54 Section 16, Constitution, 1991 (Sierra Leone).

55 Section 41(e), Internal Security (General) Act, 1984 (Lesotho)

56 Section 49, Unlawful Activities Prevention (Amendment) Act, 2004 (India); See also Avanzo, C and Prasad, D (2006) The need to reconcile Security and Human Rights, Commonwealth Human Rights, October:

http://www.humanrightsinitiative.org/publications/chogm/chogm_2007/docs/the_need_to_reconcile_security_\&_human_rights.pdf as on 21 July 2007

57 Previously included in Section 40(3), Suppression of Terrorism Bill, 2003 (Kenya)

58 Duvall, L(2005) Statement of Len Duvall, Chair of the Metropolitan

Police Authority, Press Release 43/05, 19 August: http://www.mpa.gov.uk/news/press/2005/05-043.htm as on 16 July 2007

59 Operation Kratos is still in practice and will be up for review in April 2008. See Metropolitan Police (2005) Search Powers under Section 44 Terrorism Act 2000 Standard Operations Procedures, 1 April: http://www.met.police.uk/foi/pdfs/policies/stop_and_search_s44_tact_2000_sop.pdf as on 17 May 2007

60 Asian Human Rights Commission (2006) Bangladesh: Two persons killed in "crossfire” at Jessore while in the custody of the Rapid Action Battalion, Appeal, 15 August: www.ahrchk.net/ua/mainfile.php/2006/1911/ as on 4 July 2007

61 Human Rights Watch (2006), Bangladesh: Elite Force Tortures, Kills Detainees, 14 December: http://hrw.org/english/docs/2006/12/13/bangla14844.htm as on 6 July 2007

62 State Minister for Home Affairs Lutfozzaman Babar on RAB's first anniversary: Human Rights Watch (2006 Bangladesh: Elite forces tortures, kill detainees, 14 December: http://hrw.org/english/docs/2006/12/13/bangla14844.htm as on 13 July 2007

63 Human Rights Watch (2006 Bangladesh: Elite Force Tortures, Kills Detainees, 14 December: http://hrw.org/english/docs/2006/12/13/bangla14844.htm as on 6 July 2007

64 Asia Human Rights Commission (2006) SRI LANKA: 'Murder of five Tamil youths highlights need to end impunity - Govt must protect witnesses to Trinco killings-HRW, Press Release, 29 June: http://www.ahrchk.net/statements/mainfile.php/2006statements/612/ as on 20 April 2007

65 Asia Human Rights Commission (2006) SRI LANKA: 'Murder of five Tamil youths highlights need to end impunity' - Govt must protect witnesses to Trinco killings - HRW, Press Release, 29 June: http://www.ahrchk.net/statements/mainfile.php/2006statements/612/as on 20 April 2007

66 Roth, K (2007) 'How to wear down the terrorists', The Hindu, 9 July; www.hindu.com/2007/07/09/stories/2007070954971100.htm as on 11 July 2007; See (2006)'Police probe flights terror plot', BBC News, 10 August: http://news.bbc.co.uk/1/hi/uk/4780815.stm as on 16 April 2007 
Chapter 5

1 (2007) 'Missing of Kashmir', Economic and Political Weekly, Vol. 42, No. 11, 17 March: http://www.epw.org.in/epw/uploads/articles/10361.pdf as on 15 June 2007

3 Human Rights Watch (2006) Improving Civilian Protection in Sri Lanka: Recommendations for the Government and the LTTE, p. 51, September 1: http://www.hrw.org/backgrounder/asia/srilanka0906/as on 2 April 2007

4 Human Rights Watch (2006) Improving Civilian Protection in Sri Lanka: Recommendations for the Government and the LTTE, p. 51, 1 September: http://www.hrw.org/backgrounder/asia/srilanka0906/ as on 2 April 2007

5 Human Rights Watch (2006) Improving Civilian Protection in Sri Lanka: Recommendations for the Government and the LTTE, p. 51, 1 September: http://www.hrw.org/backgrounder/asia/srilanka0906/as on 2 April 2007

6 (2006) 'The Conflict", Uganda Conflict Action Network, http://www.ugandacan.org/history.php as on 26 June 2007

7 Uganda Human Rights Commission (2005) Uganda Human Rights Commission 8th Annual Report, p. 120

8 Bowcott, O (2007) '15 murders linked to police collusion with loyalists', The Guardian, 23 January: http://www.guardian.co.uk/Northern_Ireland/Story/0,,1996450,00.html as on 2 April 2007

9 Public Security Ordinance, 1947 (Sri Lanka)

10 Section 49 (amended in 2004), Unlawful Activities (Prevention) Act, (1967) India; Section 6, Jammu and Kashmir Disturbed Areas Act, (1992) India, Section 197, Code of Criminal Procedure, (1973) India

11 Section 80, Internal Security Act, (1984) Lesotho

12 Section 32, Third Schedule of the Anti-Terrorism Act, (2002) Uganda

13 Rauch, J, Van der Spuy, E (2006) 'Police Reform in post-conflict Africa: A Review', Institute for Democracy in South Africa (IDASA), October: http://www.idasa.org.za/index.asp?page=output_details.asp\%3FRID\%3D1143\%26OTID\%3D2\%26TID\%3D17 as on 15 June 2007.

14 O'Loan, N (2006) Police Ombudsman for Northern Ireland for the Canadian Association for the Oversight of Law Enforcement: 2 October: http://www.ipcc.gov.uk/vancouver_2_10_06.pdf as on 2 April 2007

15 Human Rights Watch (2006) Improving Civilian Protection in Sri Lanka: Recommendations for the Government and the LTTE, p. 53-54, 1 September: http://www.hrw.org/backgrounder/asia/srilanka0906/as on 2 April 2007

16 Following from Section 14(e), Police Integrity Commission Act, 1996 (Australia)

17 Section 14(e) of the Police Integrity Commission Act, 1996 (Australia) now stands repealed.

18 Police Integrity Commission (2006) Management of Misconduct Risks by the New South Wales Police Counter Terrorist Coordination Command: An Assessment, p. v, September: http://www.pic.nsw.gov.au/PDF_files/CTCC.pdf as on 2 April 2007

19 Wadham, J (2005) 'Full text: IPCC statement', The Guardian, 18 August: http://www.guardian.co.uk/attackonlondon/story/0,16132,1551931 as on 2April 2006

20 Email correspondence between CHRI staff and Nick Hardwick, President, Independent Police Complaints Commission, dated 12 July 2007.

21 Independent Police Complaints Commission (2007), Jean Charles de Menezes: IPCC Makes Decision on Shooting Discipline, 11 May: http://www.ipcc.gov.uk/news/pr110507_stockwell.htm as on 17 May 2007

22 Police Ombudsman for Northern Ireland (2001) 'Statement by the Police Ombudsman for Northern Ireland on her Investigation of Matters Relating to the Omagh Bombing on August 15 1998', Police Ombudsman for Northern Ireland, p. 1, 12 December: http://cain.ulst.ac.uk/issues/police/ombudsman/po121201omagh1.pdf as on 15 June 2007

23 Police Ombudsman for Northern Ireland (2001) 'Statement by the Police Ombudsman for Northern Ireland on her Investigation of Matters Relating to the Omagh Bombing on August 15 1998', Police Ombudsman for Northern Ireland, p. 12, 12 December: http://cain.ulst.ac.uk/issues/police/ombudsman/po121201omagh1.pdf as on 15 June 2007

24 (2001) 'Omagh bomb report 'grossly unfair", BBC News, 12 December: http://news.bbc.co.uk/2/hi/uk_news/northern_ireland/1707299.stm as on 13 April 2007

25 Rauch, J, Van der Spuy, E (2006) 'Police Reform in post-conflict Africa: A Review', Institute for Democracy in South Africa (IDASA), p. 115, October: http://www.idasa.org.za/index.asp?page=output_details.asp\%3FRID\%3D1143\%26OTID\%3D2\%26TID\%3D17 as on 15 June 2007

26 Human Rights Watch (2007) Papua New Guinea: Human Rights Watch World Report 2007: http://www.unhcr.org/home/RSDCOI/45aca2a425.html as on 21 April 2007

27 Section 21(5), Protection of Human Rights Act, 1993 (India) 
29 Amnesty International (2006) Malaysia: Amnesty International's campaign to stop torture and ill-treatment in the 'war on terror', p. 3, March: http://web.amnesty.org/library/pdf/ASA280032006ENGLISH/\$File/ASA2800306.pdf as on 21 April 2007

30 Uganda Human Rights Commission (2005) Uganda Human Rights Commission 8th Annual Report, p. 114

31 Kumar, N R (2006) 'Justice Bhalla's mandate is limited', The Tribune, 31 December: http://www.tribuneindia.com/2006/20061231/edit.htm\#1 as on 3 June 2007

32 Pinto-J K (2007) 'Regretting What Might Have Been: A Critique of the National Police Commission of Sri Lanka', Roundtable on Police Reform: An Exchange of Experiences from South Asia, p. 1, 23-24 March: www.humanrightsinitiative.org/programs/aj/police/exchange/CHRI\%20PAPER\%20-\%20MARCH\%202007.doc as on 15 June 2007

33 Pinto-J K (2007) 'Regretting What Might Have Been: A Critique of the National Police Commission of Sri Lanka', Roundtable on Police Reform: An Exchange of Experiences from South Asia, p. 8, 23-24 March: www.humanrightsinitiative.org/programs/aj/police/exchange/CHRI\%20PAPER\%20-\%20MARCH\%202007.doc as on 15 June 2007

34 The case in point is Secretary of State for the Home Department $v J J$ (2006) EWCA Civ 1141: http://www.bailii.org/ew/cases/EWCA/Civ/2006/1141.html as 2 August 2007

35 'It will be some time before the judiciary is in a position to act as an effective accountability mechanism', Commonwealth Human Rights Initiative, Kenya Human Rights Commission (2006) The Police, The People, The Politics: Police Accountability in Kenya, pp51-52:

http://www.humanrightsinitiative.org/publications/police/kenya_country_report_2006.pdf as on 26 June 2007, See also International Commission of Jurists (2005) Kenya: Judicial Independence, Corruption and Reform, April: http://www.icj.org/IMG/pdf/kenyareport.pdf as on 15 June 2007

36 Lord Carlile of Berriew QC (2007) Second Report of the Independent reviewer Pursuant to Section 14(3) of the Prevention of Terrorism Act 2005: http://www.security.homeoffice.gov.uk/news-publications/publication-search/independent-reviews/lord-carlile-ann-report.pdf as on 16 April 2007

37 Lord Carlile of Berriew QC (2006) Special Report of the Independent Reviewer in Relation to Quarterly Reports to Parliament Under Section 14(1) of the Prevention of Terrorism Act 2005, 11 December: http://security.homeoffice.gov.uk/news-publications/publication-search/independent-reviews/ptareview2-06.pdf?view=Binary as on 15 June 2007

38 Travis, A, Norton T, R (2006) 'Anti-terror watchdog has reputation for fairness', The Guardian, 15 February: http://www.guardian.co.uk/print/0,,5399860-103685,00.html as on 9 July 2007

39 Liberty (2007) Extending pre-charge detention for terror suspects will make us less safe, Press Release, 1 February: http://www.liberty-human-rights.org.uk/news-and-events/1-press-releases/2007/pre-charge-detention.shtml as on 9 July 2007

40 Centre for Policy Alternatives (2007) The Centre for Policy Alternatives (CPA) welcomes the interim order issued by the Supreme Court of Sri Lanka, Press Release, 9 June:http://www.cpalanka.org/research_papers/Press_Release_on_the_interim_order.pdf as on 9 July 2007

41 Balachandran, PK (2007) 'Lankan PM apologises for expulsion of Tamils', The Hindustan Times, 10 June: http://www.hindustantimes.com/StoryPage/StoryPage.aspx ?id=534ff3a9-f452-4a0e-b9ad-433de3bf1 fa0\&MatchID1=4488\&TeamID1= 8\&TeamID2=10\&MatchType $1=1 \&$ SeriesID1=1120\&PrimaryID=4488\&Headline=Lanka+PM+apologises+for+Tamils'+expulsion as on 9 July 2007

42 (2006) 'Canada police commissioner quits', BBC News, 7 December: http://news.bbc.co.uk/2/hi/americas/6216064.stm as on 2 April 2007

43 O'Loan, N (2006) Police Ombudsman for Northern Ireland for the Canadian Association for the Oversight of Law Enforcement, p. 7, 2 October: http://www.ipcc.gov.uk/vancouver_2_10_06.pdf as on 2 April 2007

44 Commission of Inquiry into the Actions of Canadian Officials in Relation to Maher Arar (2006) Arar Commission recommends a new review agency for the RCMP's national security activities, and a new review process for 5 other agencies, Press Release, 12 December: http://www.ararcommission.ca/eng/PolicyReviewDec12-English.pdf as on 4 April 2007

45 Commission of Inquiry into the Actions of Canadian Officials in Relation to Maher Arar (2006) Arar Commission recommends a new review agency for the RCMP's national security activities, and a new review process for 5 other agencies, Press Release, 12 December: http://www.ararcommission.ca/eng/PolicyReviewDec12-English.pdf as on 4 April 2007 


\title{
BIBLIOGRAPHY
}

\author{
Books and articles
}

Ahmad, S (2006) 'Human rights too cheap in Bangladesh', One World, 8 March: http://uk.oneworld.net/article/view/128984/1/2288 as on 4 July 2007

Amnesty International (2006) United Kingdom: The Killing of Jean Charles de Menezes, 6 September:

http://web.amnesty.org/library/index/engeur450152006 as on 20 April 2007

Arar, M (2007) 'Maher's story in brief', Maherarar.ca, http://www.maherarar.ca/index.php as on 2 April 2007

Avanzo, C and Prasad, D (2006) The need to reconcile Security and Human Rights, Commonwealth Human Rights Initiative, October:

http://www.humanrightsinitiative.org/publications/chogm/chogm_2007/docs/the_need_to_reconcile_security_\&_human_rights.pdf

Balachandran, PK (2007) 'Lankan PM apologises for expulsion of Tamils', The Hindustan Times, 10 June:

http://www.hindustantimes.com/StoryPage/StoryPage.aspx?id=534ff3a9-f452-4a0e-b9ad-

433de3bf1 fa0\&MatchID1=4488\&TeamID1=8\&TeamID2=10\&MatchType 1=1\&SeriesID1=1120\&PrimaryID=4488\&Headline=Lanka+PM+apologises+for

+Tamils'+expulsion as on 9 July 2007

Barder, B (2005) 'Commentary on “Freed, But Why?", The Guardian, 8 February: http://www.barder.com/politics/liberty/crelease/guardian.php as on 2 April 2007

Bascombe, D (2004) Anti Terrorism Legislation in the Commonwealth: A briefing paper for the Commonwealth Human Rights Initiative, May: http://www.humanrightsinitiative.org/new/papers/chri_paper.pdf as on 14 June 2007

Bhelari, K (2003) 'Catch em young', Vol. 21, No. 15, The Week, pp. 18-19

Blagg, H, Morgan, N, Cunneen, C and Ferrante, A, 'Systemic Racism as a Factor in the Overrepresentation of Aboriginal People in the Victorian Criminal Justice System' in Tonry, M (ed) (1997) Ethnicity, Crime and Immigration: Comparative and Cross-National Perspectives, Crime and Justice, University of Chicago Press, Chicago

Bowcott, O (2007) '15 murders linked to police collusion with loyalists', The Guardian, 23 January:

http://www.guardian.co.uk/Northern_Ireland/Story/0,,1996450,00.html as on 2 April 2007

Buerk, R (2005) 'Bangladesh's feared elite police', BBC News, 13 December: http://news.bbc.co.uk/2/hi/south_asia/4522734.stm as on 14 June 2007

Buttler, M and Anderson, P (2007) 'Cop That: Four months after G20 protests halted a city, anti-terror police swoop in raids', Herald Sun (Australia), 15 March

Catholic Information Service for Africa (2007) 'Muslims Protest Expulsion of Cleric Linked to Terrorism', All Africa, 8 May:

http://allafrica.com/stories/200705080793.html as on 15 May

Committee to Protect Journalists (2002) Attacks on the Press in 2002: Uganda: http://www.cpj.org/attacks02/africa02/uganda.html as on 14 June 2007

Committee to Protect Journalists (2006) Sri Lanka: Freelance Tamil Journalist Arrested, November 30:

http://www.cpj.org.news/2006/asia/sri30nov06na.html as on 20 June 2007

Commonwealth Human Rights Initiative (2006) Strengthening Democratic Policing in the Commonwealth Pacific:

http://www.humanrightsinitiative.org/publications/police/strengthening_democratic_policing_in_cw_pacific.pdf as on 5 July 2007

Commonwealth Secretariat (2007) Increasing Knowledge and Awareness:

http://www.thecommonwealth.org/Internal/153657/153663/increasing_knowledge_and_awareness/ as on 7 June 2007

Dutt, V, Srikanth, VR and Nagi, S (2007) 'UK Terror: Jeep bomber also Indian', Hindustan Times, 5 July:

http://www.hindustantimes.com/htsite/StoryPage/FullcoverageStoryPage.aspx?id=b54a4d7c-607f-4e4b-8f07-

813a2d94122findiandocsinukterrorplot_Special\&MatchID1=4500\&TeamID1=2\&TeamID2=6\&MatchType $1=1 \&$ SeriesID1=1122\&MatchID2=4489\&TeamI D3=8\&TeamID4=10\&MatchType2=2\&SeriesID2=1121\&PrimaryID=4500\&Headline=UK+terror+plot\%3a+Jeep+bomber+also+Indian as on 20 July 2007

Dyer, C (2005) 'MP's demand reforms of special advocate system', The Guardian, 4 April, http://politics.guardian.co.uk/attacks/story/0,,1451564,00.html as on 24 July 2007

Gossett, S (2005) 'Report Warns of Terrorists' “Great Ramadan Offensive”', Cyberspace News Service, 8 September:

http://www.cnsnews.com/ViewSpecialReports.asp?Page=/SpecialReports/archive/200509/SPE20050908a.html as on 30 March 2007

Gregory, P and Munro, I (2006) 'Conviction quashed, 'Jihad Jack' goes free', The Age, 16 August: http://www.theage.com.au/news/national/jihad-jack-goesfree/2006/08/18/1155408020814.html as on 4 July 2007

Independent Police Complaints Commission (2007) Jean Charles de Menezes: IPCC Makes Decision on Shooting Discipline, 11 May: http://www.ipcc.gov.uk/news/pr110507_stockwell.htm as on 17 May 2007 
International Commission of Jurists (2006) Uganda-Court Martial Must End Trial of Bisegye and Co-accused, 2 February: http://www.icj.org/news.php3?id_article=3845\&lang=en as on 2 April 2007

International Federation of Journalists (2005) Courage and Censorship: Journalists and Press Freedom in South Asia 2004-2005: http://www.ifjasia.org/files/ifj_sa_press_freedom_report_overview.pdf as on 12 July 2007

International Freedom of Expression Exchange (2005) Botswana: Misa Slams 'Draconian' Security Law: http://www.ifex.org/en/content/view/full/66242/, as on 8 January 2007

Interpol (2007) Fusion Task Force: Operational Investigative Support: http://www.interpol.int/Public/FusionTaskForce/default.asp as on 14 June 2007

Interpol (2007) South African police join international security effort at Cricket World Cup,

https://www.interpol.int/Public/News/2007/CricketWorldCup20070406.asp, as on 30 July 2007

Iran Focus (2005) British lawyers want Iran opposition group de-listed, 29 November: http://www.iranfocus.com/modules/news/article.php?storyid=4640 as on 15 June 2007

Kaliopi, K (1997) Terrorism and Human Rights: Working paper submitted by Ms Kalliopi K Koufa in accordance with Sub-Commission Resolution 1996/20, E/CN.4.Sub.2/1997/28, 26 June: http://www.hri.ca/fortherecord1997/documentation/subcommission/e-cn4-sub2-1997-28.htm as on 15 June 2007

Koechler, H (2002) The United Nations and International Terrorism: Challenges to Collective Security, 15 November: http://i-p-o.org/koechler-terrorismcollective-security.htm as on 14 June 2007

Kumar, N R (2006) 'Justice Bhalla's mandate is limited', The Tribune, 31 December: http://www.tribuneindia.com/2006/20061231/edit.htm\#1 as on 3 June 2007

Kundani, A (2006) UK: Racial Profiling and anti-terror stop and search, 3 February: http://realcostofprisons.org/blog/archives/2006/02/uk_racial_profi.html as on 20 April 2007

Laithangbam, I (2004) 'Set aside proceedings against Assam Rifles personnel', The Hindu, 20 August:

http://www.hinduonnet.com/thehindu/2004/08/20/stories/2004082002841200.htm as on 7 July 2007

Mango, C (2007) 'Police Arrest 11 Terror Suspects', All Africa, 26 April: http://allafrica.com/stories/200704251224.html as on 15 May 2007

Marr, D (2007) 'Faith in the Demo Marching out the Door', The Age (Australia), 2 June: www.theage.com.au/news/in-depth/faith-in-the-demo-marching-outthe-door/2007/06/01/1180205502591.html as on 15 June 2007

Mayeda, A (2007) 'Top court annuls anti-terror measure', The Gazette, 23 February: http://www.canada.com/montrealgazette/news/story.html?id=b26cd090c9d9-4a97-a773-e870614864b4\&k=22056 as on 13 April 2007

Mehta, S (2004) 'Repeal of POTA: Justified', Legal Service India: http://www.legalservicesindia.com/articles/pota.htm as on 11 July 2007

Millicent, J (2007) 'Ibrahim Mohamed faces deportation' in Kenyan Broadcasting Corporation, 28 April: http://www.kbc.co.ke/story.asp?ID=42313 as on 15 May 2007

Molomo, MG (2001) 'Civil-Military Relations in Botswana's Developmental State', African Studies Quarterly, Vol. 5 No. 2: http://www.africa.ufl.edu/asq/v5/v5i2a3.htm as on 18 July 2007.

Murphy, B (2006) Australia Court Imposes First Control Order on Released Terror Suspect, 28 August:

http://jurist.law.pitt.edu/paperchase/2006/08/australia-court-imposes-first-control.php as on 14 June 2007

Muir, H (2007) 'Muslims must help police more, urge leaders', The Hindu, 5July: http://www.hindu.com/2007/07/05/stories/2007070551361400.htm as on 25 July 2007

National Council of Resistance of Iran (2007) European Council is not above the law, 2 February: http://www.ncr-iran.org/content/view/2832/70/ as on 20 June 2007

National Council of Resistance of Iran (2007) EU's Ministers of Economic and Financial Affairs' Council violates the verdict by the European Court, February 1: http://www.ncr-iran.org/content/view/2831/69/ as on 20 June 2007

Nicholson, B (2007) 'After the arrests: what happens now', The Age, 4 July: http://www.theage.com.au/news/national/after-the-arrests-what-happensnow/2007/07/03/1183351212554.html as on 12 July 2007

NSW Ombudsman (2007) Issues Paper: Review of Parts 2A and 3 of the Terrorism (Police Powers) Act 2002, p.2:

http://www.ombo.nsw.gov.au/publication/PDF/discussion/terrorism\%20issues\%20paper\%20april07.pdf as on 24 July 2007

Parker, T (2005) 'The Torture Question: Is Torture Ever Justified', Frontline, 18 October: http://www.pbs.org/wgbh/pages/frontline/torture/justify/3.html as on 13 June 2007 
Pinto-J K (2007) 'Regretting What Might Have Been: A Critique of the National Police Commission of Sri Lanka', Roundtable on Police Reform: An Exchange of Experiences from South Asia, 23-24 March: www.humanrightsinitiative.org/programs/aj/police/exchange/CHRI\%20PAPER\%20-\%20MARCH\%202007.doc as on 15 June 2007

Rauch, J and Van der Spuy, E (2006) 'Police Reform in post-conflict Africa: A Review', Institute for Democracy in South Africa (IDASA) October: http://www.idasa.org.za/index.asp?page=output_details.asp\%3FRID\%3D1143\%26OTID\%3D2\%26TID\%3D17 as on 15 June 2007

Roth, K (2007) 'How to wear down the terrorists', The Hindu, 9 July; www.hindu.com/2007/07/09/stories/2007070954971100.htm as on 11 July 2007 Roy, A (2006) 'India's Shame', Guardian Unlimited, 15 December: http://www.guardian.co.uk/india/story/0,,1972788,00.html as on 20 April 2007 Roy, A (2006) 13 December: The strange case of the attack on the Indian Parliament, Penguin Books, Delhi

Saul, B (2005) 'Definition of "Terrorism” in the UN Security Council: 1985-2004', Chinese Journal of International Law, Vol. 4, No. 1, pp. 141-166 Singh, U K (2007) The State, Democracy and Anti-terror Laws in India, Sage Publications, New Delhi.

Smith, J E (2003) 'New Zealand's Anti-Terrorism Campaign: Balancing Civil Liberties, National Security, and International Responsibilities', Wellington, 28 November: http://www.fulbright.org.nz/voices/axford/docs/smithj.pdf as on 1 August 2007

South Asia Human Rights Documentation Centre, Armed Forces Special Powers Act: A Study in National Security Tyranny, http://www.hrdc.net/sahrdc/resources/armed_forces.htm as on 18 July 2007

Stone, R (2006) 'Police Powers and Human Rights in the Context of Terrorism', Managerial Law, Vol. 48, No. 4, pp. 384-399

Travis, A and Norton T, R (2006) 'Anti-terror watchdog has reputation for fairness', The Guardian, 15 February: http://www.guardian.co.uk/print/0,5399860$103685,00 . \mathrm{html}$ as on 9 July 2007

Tyson, A S (2005) 'U.S. Pushes Anti-Terrorism in Africa', Washington Post, 26 July: www.washingtonpost.com/wpdyn/content/article/2005/07/25/AR2005072501801.html as on 15 June 2007

Verkaik, R (2005) 'Release of terror suspect increases pressure on Clarke', The Independent, 2 February: findarticles.com/p/articles/mi_qn4158/is_20050202/ai_n9498825 as on 11 July 2007

Wadham, J (2005) 'Full text: IPCC statement', The Guardian, 18 August: http://www.guardian.co.uk/attackonlondon/story/0,16132,1551931,00.html as on 2 April 2006

(2007) 'Reid to unveil anti-terror plans', BBC News, 7 June: http://news.bbc.co.uk/1/hi/uk_politics/6727267.stm as on 8 June 2007.

(2007) 'Liberty Rejects the Home Secretary's Blustering Rhetoric on Control Orders', Liberty, 24 May: http://www.liberty-human-rights.org.uk/news-andevents/1-press-releases/2007/control-order-response.shtml as on 6 June 2007

(2007) 'Missing of Kashmir', Economic and Political Weekly, Vol. 42, No. 11, 17 March: http://www.epw.org.in/epw/uploads/articles/10361.pdf as on 15 June 2007

(2007) 'Stop and search 'overused and ineffective", Politics.co.uk, 23 March http://www.politics.co.uk/news/bills/organised-crime-bill/stop-and-searchoverused-and-ineffective-\$469255.htm as on 30 July 2007

(2007) 'Stop and Search Powers Damaging', BBC News, 31 May: http://news.bbc.co.uk/2/hi/uk_news/england/london/6706885.stm as on 14 June 2007

(2007) 'Terror suspects put on control orders should be prosecuted', The Independent, 20 February:

http://news.independent.co.uk/uk/politics/article2287031.ece as on 18 April 2007

(2007) 'Campbell attacks stop-and-search', BBC News, 23 March: http://news.bbc.co.uk/1/hi/uk_politics/6482263.stm as on 30 July 2007

(2006) 'Canada police commissioner quits', BBC News, 7 December: http://news.bbc.co.uk/2/hi/americas/6216064.stm as on 2 April 2007

(2006) 'Police probe flights terror plot', BBC News 10 August: http://news.bbc.co.uk/1/hi/uk/4780815.stm as on 20 June 2007

(2006) 'The Conflict", Uganda Conflict Action Network,

http://www.ugandacan.org/history.php as on 26 June 2007

(2005) 'Blair defeated over terror laws', BBC News, 9 November: http://news.bbc.co.uk/1/hi/uk_politics/4422086.stm as on 14 June 2007

(2005) 'Good Response to CCTV bombs plea', BBC News, 23 July: http://news.bbc.co.uk/1/hi/uk/4710239.stm as on 23 July 2007

(2005) 'Muslim face increased stop and search', The Guardian, 2 March: http://www.guardian.co.uk/guardianpolitics/story/0,1428387,00.html as on 9 May 2007

(2003) '12 yr-old boy arrested under POTA', The Times of India, 20 February: http://timesofindia.indiatimes.com/articleshow/38009357.cms as on 23 July 2007 
(2003) 'Bali death toll set at 202', BBC News, 19 February, http://news.bbc.co.uk/1/hi/world/asia-pacific/2778923.stm as on 11 July 2007.

(2001) 'Omagh bomb report 'grossly unfair", BBC News, 12 December: http://news.bbc.co.uk/2/hi/uk_news/northern_ireland/1707299.stm as on 13 April 2007

Reports

Advisory Council of Jurists (2004) Final Report on the Reference on the Rule of Law in Combating Terrorism, released at the Asia Pacific Forum of National Human Rights Institutions, Kathmandu, 16-18 February: as on 15 June 2007

Amnesty International, Cageprisoners, Centre for Constitutional Rights, Centre for Human Rights and Global Justice, Human Rights Watch, Reprieve (2007) Off the Record: U.S. Responsibility for Enforced Disappearances in the “War on Terror": http://www.statewatch.org/news/2007/jun/us-disappeared.pdf as on 7 June 2007

Amnesty International New Zealand Section (2007) Ahmed Zaoui Timeline of Events:

http://www.amnesty.org.nz/web/pages/home.nsf/dd5cab6801f1723585256474005327c8/04d345f73f3d0469cc257321001b4e9c!OpenDocument as on 27 July 2007

Amnesty International (2005) Kenya: The Impact of “Anti-Terrorism” Operations on Human rights, 23 March:

http://web.amnesty.org/library/index/engafr320022005 as on 2 April 2007

Amnesty International (2006) Asia-Pacific: India: http://web.amnesty.org/report2006/ind-summary-eng as on 2 April 2007

Amnesty International (2006) Malaysia: Amnesty International's campaign to stop torture and ill-treatment in the 'war on terror', 28, March:

http://web.amnesty.org/library/pdf/ASA280032006ENGLISH/\$File/ASA2800306.pdf as on 21 April 2007

Amnesty International (2006) Pakistan: Human rights ignored in the "war on terror": http://web.amnesty.org/library/index/engasa330352006 as on 13 April 2007

Amnesty International (2007) Amnesty, Ethiopia: Incommunicado detention/fear of torture or ill-treatment/health concern, 16 April:

http://web.amnesty.org/library/Index/ENGAFR250052007 as on 12 July 2007

Commonwealth Human Rights Initiative, Kenya Human Rights Commission (2006) The Police, The People, The Politics: Police Accountability in Kenya: http://www.humanrightsinitiative.org/publications/police/kenya_country_report_2006.pdf as on 26 June 2007

Commonwealth Human Rights Initiative (2007) Easier Said Than Done: A report on the commitments of the Commonwealth Members of the Human Rights Council: http://www.humanrightsinitiative.org/publications/hradvocacy/easier_said_than_done.pdf as on 17 July 2007

Financial Action Task Force (2006) Annual Review of Non-Cooperative Countries and Territories 2005-2006, June: http://www.fatfgafi.org/dataoecd/0/0/37029619.pdf as on 25 June 2007

Human Rights Watch (2007) People Fleeing Somalia War Secretly Detained, 31 March: as on 12 July 2007

Human Rights Watch (2007) Human Rights Watch World Report 2007 - Papua New Guinea: http://www.unhcr.org/home/RSDCOI/45aca2a425.html as on 21 April 2007

Human Rights Watch (2007) Pakistan: Country Summary, January: http://hrw.org/wr2k7/pdfs/pakistan.pdf as on 8 April 2007

Human Rights Watch (2007) Papua New Guinea: Human Rights Watch World Report 2007: http://www.unhcr.org/home/RSDCOI/45aca2a425.html as on 21 April 2007

Human Rights Watch (2006) Improving Civilian Protection in Sri Lanka: Recommendations for the Government and the LTTE, p. 51, 1 September: http://www.hrw.org/backgrounder/asia/srilanka0906/ as on 2 April 2007

Human Rights Watch (2006) Bangladesh: Elite Force Tortures, Kills Detainees, 14 December: http://hrw.org/english/docs/2006/12/13/bangla14844.htm as on 6 July 2007

Human Rights Watch (2002) Malaysia's Internal Security Act and Suppression of Political Dissent: http://hrw.org/backgrounder/asia/malaysia-bck-0513.htm as on 30 March 2007

International Commission of Jurists (2005) Kenya: Judicial Independence, Corruption and Reform, April: http://www.icj.org/IMG/pdf/kenyareport.pdf as on 15 June 2007

Kaliopi K. Koufa (2004) Specific human rights issues: new priorities, in particular Terrorism and counter-terrorism; Terrorism and human rights, Final report to the $56^{\text {th }}$ session of the Sub-Commission on the Promotion and Protection of Human Rights, E/CN.4/Sub.2/2004/40, 25 June.

Lord Carlile of Berriew QC (2007) Lord Carlile Report: Control Orders are "Necessary" and "Justifiable", 19 February: http://security.homeoffice.gov.uk/news-publications/news-speeches/Lord-carlile-report as on 16 April 2007 
Lord Carlile of Berriew QC (2007) Second Report of the Independent reviewer Pursuant to Section 14(3) of the Prevention of Terrorism Act 2005 , 19 February: http://www.statewatch.org/news/2007/feb/uk-pta-carlile-ann-report.pdf as on 15 June 2007

Lord Carlile of Berriew QC (2006) Special Report of the Independent Reviewer in Relation to Quarterly Reports to Parliament Under Section 14(1) of the Prevention of Terrorism Act 2005, 11 December: as on 15 June 2007

Metropolitan Police (2005) Search Powers under Section 44 Terrorism Act 2000 Standard Operations Procedures, 1 April: http://www.met.police.uk/foi/pdfs/policies/stop_and_search_s44_tact_2000_sop.pdf as on 17 May 2007

Police Integrity Commission (2006) Management of Misconduct Risks by the New South Wales Police Counter Terrorist Coordination Command: An Assessment, p. v, September: http://www.pic.nsw.gov.au/PDF_files/CTCC.pdf as on 2 April 2007

Privacy International (2004) Terrorism Profile - South Africa,

http://www.privacyinternational.org/article.shtml?cmd\%5B347\%5D=x-347-66677\#_ftn1, as on 30 July 2007

Scheinin, M (2005) Promotion and Protection of Human Rights: Report of the Special Rapporteur on the promotion and protection of human rights and fundamental freedoms while countering terrorism, UN Doc E/CN.4/2006/98, 28 December: as on 15 June 2007

Scheinin, M (2006) Australia: study on human rights compliance while countering terrorism: Implementation of General Assembly Resolution 60/251 of 15 March 2006, UN Doc A/HRC/4/26/Add.2, 14 December: http://www.ohchr.org/pacific/docs/AustraliaA.HRC.4.26.Add.3.pdf as on 5 July 2007

Scheinin, M (2007) Implementation of General Assembly Resolution 60/251 of 15 March 2006 Entitled "Human Rights Council, A/HRC/4/26, 29 January

Surveillance Studies Network (2006) A Report on the Surveillance Society, September:

http://www.ico.gov.uk/upload/documents/library/data_protection/practical_application/surveillance_society_full_report_2006.pdf as on 23 July 2007

Uganda Human Rights Commission (2005) Uganda Human Rights Commission $8^{\text {th }}$ Annual Report, Uganda

United Nations General Assembly (2007) Report of the Ad Hoc Committee Established by the General Assembly Resolution 51/210 of 17 December 1996, UN Doc A/62/37, annex: http://daccessdds.un.org/doc/UNDOC/GEN/N07/242/89/PDF/N0724289.pdf?OpenElement as on 11 July 2007

United Nations on Drugs and Crime (2006) General Assembly: Sixth Committee Summary Record of the 21 $1^{s t}$ Meeting, UN Doc A/C.6/61/SR.21, 27 November: http://domino.un.org/UNISPAL.NSF/eed216406b50bf6485256ce10072f637/012c19e8b3e74bd3852572c3006f8db7! OpenDocument as on 21 June 2007

United Nations General Assembly, Implementation of general assembly resolution 60/251 of 15 March 2006 entitled "Human Rights Council": Report of the Special Rapporteur on the promotion and protection of human rights and fundamental freedoms while countering terrorism, AA/hrc/4/26/add.1, 15 March 2007

US Department of State (2007) Kenya: Security Assistance, US Department of state website: www.state.gov/t/pm/64672.htm as on 7 July 2007

Press releases and appeals

Amnesty International (2006) Pakistan: Enforced disappearances in the 'war on terror', Press Release, 29 September: http://web.amnesty.org/library/Index/ENGASA330382006 as on 11 July 2007

Asian Centre for Human Rights (2003) Appeal for Complaint for Enforcement of Juvenile Justice (Care and Protection) Act 2000 with Regard to 14-year-old Ms Mayanti Raj Kumari of Pandrani Village, Appeal, 7 October: http://achrweb.org/countries/india/jharkhand/POTA0303.htm as on 10 May 2007

Asia Human Rights Commission (2006) Sri Lanka: “Murder of five Tamil youths highlights need to end impunity" - Govt Must protect Witnesses to Trinco Killings - HRW, Appeal, 29 June: http://www.ahrchk.net/statements/mainfile.php/2006statements/612/ as on 20 April 2007

Asian Human Rights Commission (2006) Bangladesh: Two persons killed in "crossfire" at Jessore while in the custody of the Rapid Action Battalion, Appeal, 15 August: www.ahrchk.net/ua/mainfile.php/2006/1911/ as on 4 July 2007

Centre for Policy Alternatives (2007) The Centre for Policy Alternatives (CPA) welcomes the interim order issued by the Supreme Court of Sri Lanka, Press Release, 9 June: http://www.cpalanka.org/research_papers/Press_Release_on_the_interim_order.pdf as on 9 July 2007

Commission of Inquiry into the Actions of Canadian Officials in Relation to Maher Arar (2006) Arar Commission recommends a new review agency for the RCMP's national security activities, and a new review process for 5 other agencies, Press Release, 12 December:

http://www.ararcommission.ca/eng/PolicyReviewDec12-English.pdf as on 4 April 2007

Commonwealth Heads of Government (2001) Commonwealth Statement on Terrorism, 25 October:

http://www.thecommonwealth.org/document/34293/35144/35145/report_of_the_commonwealth_committee_on_terrorism.htm as on 22 June 2007

Commonwealth Secretariat (2005) International Human Rights Day: Message by Commonwealth Secretary-General Don McKinnon, Press Release, 10 December: http://www.genderandtrade.org/press/31555/34582/147750/international_human_rights_day_10_december_2005.htm as on 25 July 2007. 
Duvall, L (2005) Statement of Len Duvall, Chair of the Metropolitan Police Authority, Press Release 43/05, 19 August:

http://www.mpa.gov.uk/news/press/2005/05-043.htm as on 16 July 2007

Eminent Jurists Panel on Terrorism, Counter-Terrorism and Human Rights (2006) Eminent Jurists Panel Concludes Australia Hearing on Counter-Terrorism Laws, Practices and Policies, Press Release, 17 March: http://ejp.icj.org/IMG/press_release_final.pdf as on 7 July 2007

HURINET (2007) Break Down of the Rule of Law, Public Order, Safety and Justice, Press Release, 5 March:

www.isis.or.ug/downloads/statementonjudiciary.pdf as on 21 June 2007

HURINET (2007) Human Rights Network Uganda Calls Upon the Government to Respect and listen to the Views of Citizens, Press Release, 13 April: www.isis.or.ug/downloads/statementonjudiciary.pdf as on 15 June 2007

International Secretariat of the World Organisation against Torture (2007) Bangladesh: State of emergency causing the death of at least 19 persons, including a minor, by security forces, Press release, 26 January: http://www.crin.org/resources/infodetail.asp?id=12374 as on 27 June 2007

Liberty (2007) Extending pre-charge detention for terror suspects will make us less safe, Press Release, 1 February: http://www.liberty-humanrights.org.uk/news-and-events/1-press-releases/2007/pre-charge-detention.shtml as on 9 July 2007

McKinnon, D (2005) International Human Rights Day, 10 December 2005: Message by Commonwealth Secretary-General Don McKinnon, Press Release, 9 December 2005: http://www.thecommonwealth.org/press/34582/147750/international_human_rights_day_10_december_2005.htm as on 15 June 2007

Police Ombudsman for Northern Ireland (2001) 'Statement by the Police Ombudsman for Northern Ireland on her Investigation of Matters Relating to the Omagh Bombing on August 15 1998', Police Ombudsman for Northern Ireland, 12 December: as on 15 June 2007

United Nations (2006) Madrid, Spain, 7 September 2006 - Secretary-General's press conference with Spanish Prime Minister Jose Luis Rodriguez Zapatero (Unofficial Transcript), 7 September: http://www.un.org/apps/sg/offthecuff.asp?nid=937 as on 15 June 2007

United Nations Press Service (2007) UN meeting to focus on strengthening counter-terrorism efforts in West Africa, Press Release, 10 July.

Speeches

O'Loan, N (2006) Police Ombudsman for Northern Ireland for the Canadian Association for the Oversight of Law Enforcement, 2 October: http://www.ipcc.gov.uk/vancouver_2_10_06.pdf as on 2 April 2007

Manuals

Commonwealth Secretariat (2006) Commonwealth Manual on Human Rights Training for Police Training, June: http://www.thecommonwealth.org/Templates/Internal.asp?NodeID=152764 as on 27 June 2007

Commonwealth Secretariat (2002) Implementation Kits for the International Counter-Terrorism Conventions, Criminal Law Section, Legal and Constitutional Affairs Division: www.thecommonwealth.org/Internal/38061/documents/ as on 22 June 2007

Commonwealth Secretariat (2002) Model Legislative Provisions on Measures to Counter Terrorism, September: as on 27 June 2007

Commonwealth Secretariat (2002) Explanatory Guide to the Model Legislative Provisions on Measures to Counter Terrorism, September: http://www.thecommonwealth.org/shared_asp_files/uploadedfiles/\%7B32AF830D-F83A-4432-8051-750C789531A5\%7D_final_terrorism_law.pdf as on 27 June 2007

Council of Europe Committee of Ministers (2001) Recommendation Rec (2001) 10 on the European Code of Police Ethics: http://www.legislationline.org/legislation.php?tid=155\&lid=4886 as on 15 July 2007

Office of the United Nations High Commissioner of Human Rights (1997) Human Rights and Law Enforcement: A Manual on Human Rights Training for the Police, UN Doc HR/P/PT/5: http://www.ohchr.org/english/about/publications/docs/police_intro.pdf as on 22 June 2007

Office of the United Nations High Commissioner of Human Rights (2002) Human Rights and Law Enforcement: A Trainer's Guide on Human Rights for the Police UN Doc HR/P/PT/5/Add.2: http://www.ohchr.org/english/about/publications/docs/train5add2.pdf as on 27 June 2007

Office of the United Nations High Commissioner of Human Rights, International Human Rights Standards for Law Enforcement: A Pocket Book on Human Rights for the Police: http://www.ohchr.org/english/about/publications/docs/pocketbook.pdf as on 27 June 2007

Southern African Regional Police Chiefs Co-operation Organisation, Code of Conduct:

www.amnesty.ie/../youth\%20and\%20students/Southern\%20African\%20Regional\%20Police\%20Chiefs\%20Co.pdf as on 27 June 2007

Court Judgements

England and Wales Court of Appeal (Civil Division) Decisions (2006) Secretary of State for the Home Department v JJ, EWCA Civ 1141, 1 August: http://www.bailii.org/ew/cases/EWCA/Civ/2006/1141.html as on 27 June 2007 
House of Lords of the United Kingdom (2005) A v Secretary of State for the Home Department, UKHL 71, 8 December: http://www.publications.parliament.uk/pa/ld/ldjudgmt.htm\#2005 as on 27 June 2007

House of Lords (UK) (2004) A (FC) and others (FC) (Appellants) v. Secretary of State for the Home Department (Respondent), 16 December, http://www.publications.parliament.uk/pa/ld200405/ldjudgmt/jd041216/a\&oth-1.htm as on 23 July 2007

Inter-American Court of Human Rights (1988) Velasquez Rodriguez Case, Case 9799 (Peru)

International Criminal Tribunal for the ex-Yougoslavia (1998) The Prosecutor v. Anto Furundzija, Case No. IT-95-17/1-T, 10 December, http://www.un.org/icty/Supplement/supp1-e/furundzija.htm as on 17 July 2007

New Zealand Court of Appeal (2004) Ahmed Zaoui v Attorney General, CA 166/04, 17 September

New Zealand Supreme Court (2005) Attorney-General v Ahmed Zaoui \&Ors, NZSC 38, 21 June

Supreme Court of Canada (2007) Charkaoui v Canada, SCC 9, 23 February: http://scc.lexum.umontreal.ca/en/2007/2007scc9/2007scc9.html as on 29 June 2007

Supreme Court of India (1997) DK Basu vs. State of West Bengal, 1 SC 1 (India): http://www.alrc.net/doc/mainfile.php/cl_india/143/ as on 16 July 2007

Communique, declarations, resolutions, and treaties

African Union (1981) African Charter on Human and Peoples' Rights (Banjul's Charter): www.hrcr.org/docs/Banjul/afrhr.html

Commonwealth Heads of Government (2001) Commonwealth Statement on Terrorism, 25 October:

http://www.thecommonwealth.org/document/34293/35144/35145/report_of_the_commonwealth_committee_on_terrorism.htm

Commonwealth Heads of Government Meet (1991) Commonwealth Harare Declaration: 20 October:

www.thecommonwealth.org/Internal/20723/34457/harare_commonwealth_declaration/ as on 27 July 2007

Commonwealth Heads of Government Meet (2002) Coolum Communiqué CHOGM 2002:

http://thecommonwealth.org/Internal/33374/36310/36315/coolum_communique/

Commonwealth Law Ministers (2002) Communiqué of the Law Ministers' Meeting Kingstown, St Vincent \& the Grenadines:

http://www.thecommonwealth.org/shared_asp_files/uploadedfiles/\%7B848FB421-E170-4071-A19D-BB3B5CDDEA50\%7D_Final\%20Communique.pdf

Commonwealth Secretariat (1991) Commonwealth Harare Declaration:

http://www.thecommonwealth.org/Internal/20723/34457/harare_commonwealth_declaration/

Commonwealth Secretariat (1971) Singapore Declaration of Commonwealth Principles:

http://www.thecommonwealth.org/Internal/20723/32987/singapore_declaration_of_commonwealth_principles/

Council of Europe (2005) Convention on the Prevention of Terrorism: http://conventions.coe.int/Treaty/EN/Treaties/Html/196.htm

Council of Europe (1950) European Convention on Human Rights and Fundamental Freedoms: http://conventions.coe.int/Treaty/en/Treaties/Html/005.htm

Email correspondence between CHRI staff and Nick Hardwick, President, Independent Police Complaints Commission, dated 12 July 2007

Gonzales, A (2002) Memorandum from White House Counsel Alberto Gonzales to President Bush, 18 January:

http://news.findlaw.com/usatoday/docs/torture/gnzls12502mem2gwb2.html as on 27 June 2007

Office of United Nations Commission for Human Rights (2005) Resolution 2005/80, E/CN/4/RES/2005/80, 25 January:

http://daccessdds.un.org/doc/UNDOC/GEN/G05/104/91/PDF/G0510491.pdf?OpenElement

Office of the United Nations High Commissioner of Human Rights (1966) International Covenant on Civil and Political Rights:

http://www.ohchr.org/english/law/ccpr.htm as on 27 June 2007

Office of the High Commissioner for Human Rights (1990) Basic Principles on the Use of Force and Firearms by Law Enforcement Officials:

http://www.unhchr.ch/html/menu3/b/h_comp43.htm

Office of the United Nations High Commissioner for Human Rights (1966) International Covenant on Civil and Political Rights:

http://www.ohchr.org/english/law/ccpr.htm

Office of the High Commissioner for Human Rights (1966) International Covenant on Economic, Social and Cultural Rights:

http://www.unhchr.ch/html/menu3/b/a_cescr.htm

Organization of African Unity (1999) Convention on the Prevention and Combating of Terrorism: http://www.africaunion.org/root/AU/Documents/Treaties/Text/Algiers_convention\%20on\%20Terrorism.pdf

Organization of American States (1969) American Convention of Human Rights, 22 November: www.hrcr.org/docs/American_Convention/oashr.html 
Organization of American States (1985) Inter-American Convention to Prevent and Punish Torture: http://www.oas.org/juridico/English/Treaties/a-51.htmlF

Organization of American States (2002) Inter-American Convention Against Terrorism:

http://www.oas.org/xxxiiga/english/docs_en/docs_items/AGres1840_02.htm

United Nations (2005) International Convention for the Suppression of Acts of Nuclear Terrorism: http://www.un.org/terrorism/instruments.html

United Nations (2005) Protocol to the Convention for the Suppression of Unlawful Acts against the Safety of Maritime Navigation: http://www.un.org/terrorism/instruments.html\#conv6

United Nations (2002) Optional Protocol to the Convention Against Torture and Other Cruel, Inhuman or Degrading Treatment or Punishment: http://www.ohchr.org/english/law/cat-one.htm

United Nations (1999) International Convention for the Suppression of the Financing of Terrorism: http://untreaty.un.org/English/Terrorism/Conv12.pdf

United Nations High Commissioner for Human Rights (1998) Human Rights and Terrorism: Commission on Human Rights Decision 1998/107: http://www.unhchr.ch/Huridocda/Huridoca.nsf/TestFrame/7386b4115143434d8025666a004dbd51?Opendocument

United Nations (1991) Convention on the Marking of Plastic Explosives for the Purpose of Detection United Nations: http://untreaty.un.org/English/Terrorism/Conv10.pdf

United Nations (1990) Basic Principles on the Use of Force and Firearms by Law Enforcement Officials: http://www.ohchr.org/english/law/firearms.htm United Nations (1989) Principles on the Effective Prevention and Investigation of Extra-Legal, Arbitrary and Summary Executions: http://www.unhchr.ch/html/menu3/b/54.htm

United Nations (1988) Convention for the Suppression of Unlawful Acts Against the Safety of Maritime Navigation: http://www.un.org/terrorism/instruments.html

United Nations (1988) Convention for the Suppression of Terrorist Bombings: http://www.un.org/terrorism/instruments.html

United Nations (1987) Convention Against Torture and Other forms of Cruel, Inhuman and Degrading Treatment:

www.unhchr.ch/html/menu3/b/h_cat39.htm

United Nations (1980) Convention on the Physical Protection of Nuclear Material: http://untreaty.un.org/English/Terrorism/Conv6.pdf

United Nations (1979) Code of Conduct for Law Enforcement Officials, 17 December: http://ohchr.org/english/law/pdf/codeofconduct.pdf

United Nations (1979) International Convention Against the Taking of Hostages: http://untreaty.un.org/English/Terrorism/Conv5.pdf

United Nations (1971) Convention for the Suppression of Unlawful Acts Against the Safety of Civil Aviation: http://www.un.org/terrorism/instruments.html United Nations (1970) Convention on Offences and Certain Other Acts Committed on Board Aircraft: http://www.un.org/terrorism/instruments.html United Nations (1963) Convention on Offences and Certain Other Acts Committed on Board Aircraft: http://untreaty.un.org/English/Terrorism/Conv1.pdf United Nations (1948) Universal Declaration of Human Rights (UDHR): http://www.un.org/Overview/rights.html

United Nations (1945) United Nations Charter: http://www.un.org/aboutun/charter/

United Nations General Assembly (2006) UN Global Counter-Terrorism Strategy and corresponding Plan of Action: http://www.un.org/terrorism/strategycounter-terrorism.html

United Nations General Assembly (1994) Resolution 49/60, 9 December: http://www.un.org/documents/ga/res/49/a49r060.htm

United Nations General Assembly (1979) Resolution 34/169 Code of Conduct for Law Enforcement Officials, 17 December: http://www.un.org/documents/ga/res/34/a34res169.pdf

United Nations (1948) Universal Declaration of Human Rights (UDHR): as on 27 June 2007

United Nations Human Rights Committee (2001) General Comment No 29 States of Emergency (Article 4), UN Doc CCPR/C/21/Rev.1/Add.11, 31 August: http://www.unhchr.ch/tbs/doc.nsf/0/71eba4be3974b4f7c1256ae200517361?Opendocument

United Nations Human Rights Committee (1982) General Comment No. 1 on Article 6, UN Doc A/37/40:

http://www.unhchr.ch/tbs/doc.nsf/0/84ab9690ccd81fc7c12563ed0046fae3?Opendocument

United Nations Office on Drugs and Crime (2006) General Assembly: Sixth Committee Summary Record of the 21'st Meeting, A/C.6/61/SR.21, 27 November: http://domino.un.org/UNISPAL.NSF/eed216406b50bf6485256ce10072f637/012c19e8b3e74bd3852572c3006f8db7!OpenDocument

United Nations Security Council (2004) Resolution 1566, 8 October:

http://donmimo.un.org/UNISPAL.NSF/db942872b9eae454852560f6005a76fb/ebd1ed0b67c36bbf852570d600654086!OpenDocument 


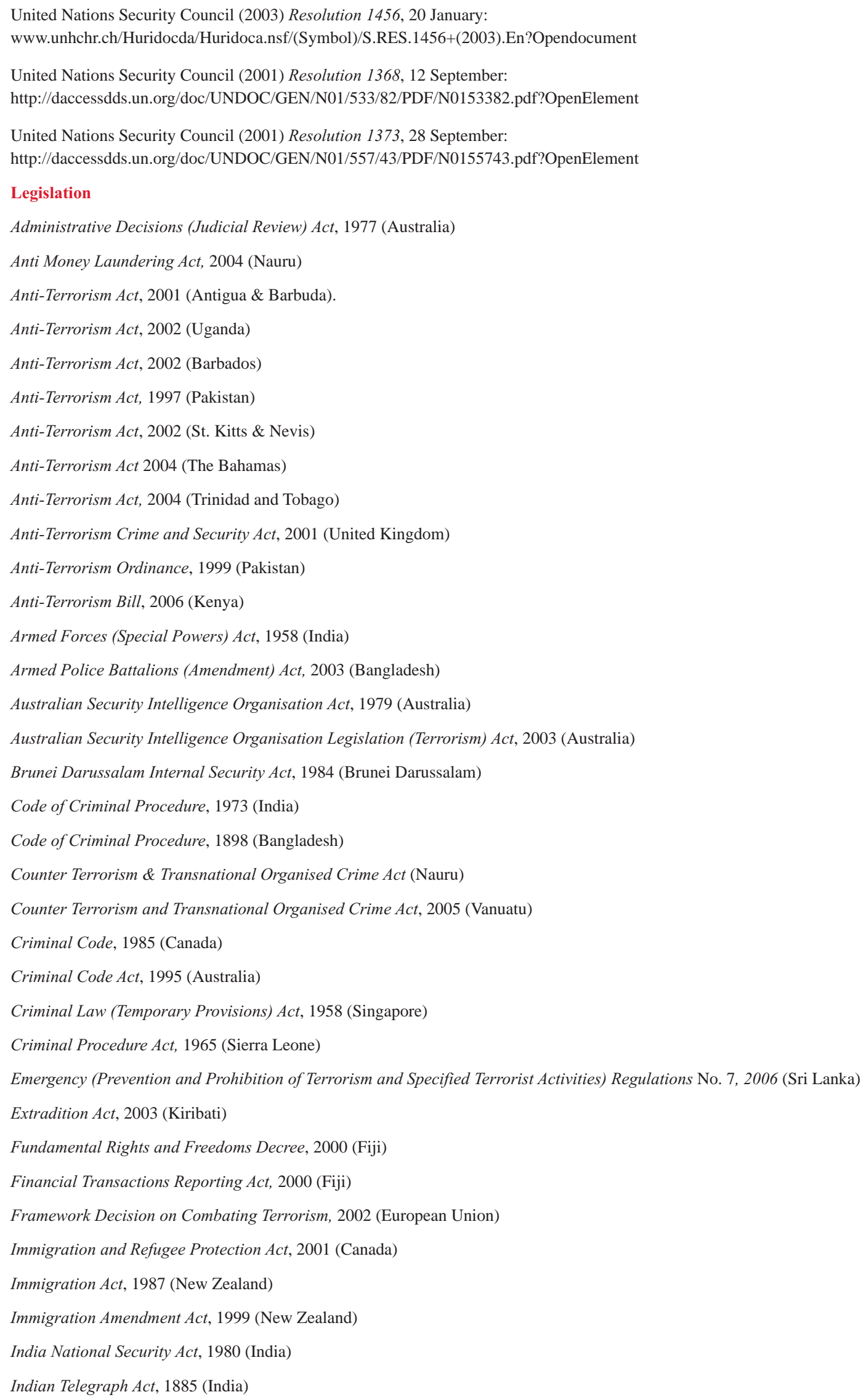


Internal Security Act, 1984 (Brunei Darussalam)

Internal Security Act, 1960 (Malaysia)

Internal Security Act, 1963 (Singapore)

Internal (Amended) Security Act, 1988 (Malaysia)

Internal Security (General) Act, 1984 (Lesotho)

International Terrorism (Emergency Powers) Act, 1987 (New Zealand)

Jammu and Kashmir Disturbed Areas Act, 1992 (India)

Penal Code (the Bahamas)

Penal Code (Amendment) Act, 2003 (Vanuatu)

Police and Evidence Act, 1984 (United Kingdom)

Police and Criminal Evidence Act, 1984 (United Kingdom)

Police Integrity Commission Act, 1996 (Australia)

Preventative Detention Act, 1962 (Tanzania)

Prevention of Terrorism Act, 2005 (Antigua and Barbuda)

Prevention of Terrorism Act, (India)

Prevention of Terrorism Act, 1990 (Maldives)

Prevention of Terrorism Act, 2004 (Seychelles)

Prevention of Terrorism Act, 1979 (Sri Lanka)

Prevention of Terrorism Act, 2002 (Tanzania)

Prevention and Suppression of Terrorism Act, 2002 (Samoa)

Protection of Constitutional Democracy Against Terrorism and Related Activities Act, 2004 (South Africa)

Protection of Human Rights Act, 1993 (India)

Public Safety Act, 2002 (Canada)

Public Security Ordinance, 1947(Sri Lanka)

Special Powers Act, 1974 (Bangladesh)

Suppression of Terrorism Bill, 2003 (Kenya)

Telecommunications (Interception) Act, 1979 (Australia)

Terrorism Act, 2003 (Grenada)

Terrorism Act, 2000 (UK)

Terrorism Act, 2006 (UK)

Terrorism Prevention Bill, 2003 (Jamaica)

Terrorist and Disruptive Activities Act, 1985 (India)

United Nation (Anti-Terrorism Measures) Regulations, 2001(Singapore)

Unlawful Activities Prevention (Amendment) Act, 2004 (India)

Unlawful Activities (Prevention) Act, 1967 (India)

Websites

Australian Institute of Police Management (2007) 'Leadership in Counter Terrorism Program (LinCT)', Australian Institute of Police Management Website: http://www.aipm.gov.au/linct.html as on 15 July 2007

Arar, M, Maher Arar Website: http://www.maherarar.ca as on 15 July 2007

Commonwealth Secretariat Human Rights Unit (2007) Increasing Knowledge and Awareness: Human Rights Training for Police Trainers in the Commonwealth: http://www.thecommonwealth.org/Internal/39419/153663/increasing_knowledge_and_awareness/ as on 20 July 2007 
Organisation and structure of the Assam Rifle, Assam Rifle website: http://www.assamrifles.com/OrgStruct.htm as on 17 July 2007

Serious Organised Crime Agency, United Kingdom, Diversity and Equal Opportunities: Managing Equality of Opportunity and Diversity: http://www.soca.gov.uk/recruitment/diversity.html as on 16 July 2007

Sri Lanka Police Service Website: http://www.police.lk/divisions/stf.asp

United Nations, Ad Hoc Committee Established by General Assembly Resolution 51/210 of 17 December 1996: http://www.un.org/law/terrorism/index.html as on 15 July 2007

UNDP Malaysia (2005-2007) Capacity Development of the Integrity Institute of Malaysia for the Implementation of the National Integrity Plan: http://www.undp.org.my/index.php?navi_id=45 as on 11 July 2007 


\section{CHRI'S PREVIOUS REPORTS TO CHOGM}

Police Accountability: Too Important to Neglect, Too Urgent to Delay (2005)

The police accountability report explores the critical relationship between accountability of the police in the Commonwealth and the protection and promotion of basic rights in communities. The report considers the defining elements of good and bad policing and puts forward a road map for police reform based on accountability to the law, accountability to democratic government, and accountability to the community.

Open Sesame: Looking for the Right to Information in the Commonwealth (2003)

Open Sesame demonstrates the value to democracy and development of ensuring that people have a guaranteed right to access information held by government and other powerful institutions as well as the urgency of enabling that right. The international standards, practice and lessons expounded in this report offer a practical solution to the all too evident systemic governance problems that beset most Commonwealth countries today through the neglect of this fundamental right.

Human Rights and Poverty Eradication: A Talisman for the Commonwealth (2001)

The Talisman report shows how poverty is an abuse of human rights. It advocates the adoption of a rights-based approach to eradicating the large-scale poverty that continues to exist in the Commonwealth. It points to the gap between the rhetoric the Commonwealth espouses and the reality of people's lives. The report urges member governments to cooperate to fulfill the many solemn commitments made at successive CHOGMs or risk the Commonwealth losing its relevance.

\section{Over a Barrel - Light Weapons and Human Rights in the Commonwealth (1999)}

Over a Barrel exposed a tragic contradiction in the modern Commonwealth in that although human rights are recognised as central to the Commonwealth, millions of light weapons flow freely, jeopardising safety, development and democracy. The report outlines urgent recommendations to the Commonwealth for curbing the reach of light weapons in member countries.

\section{The Right to a Culture of Tolerance (1997)}

This report focused on two themes: ethnic and religious intolerance as an urgent problem throughout the Commonwealth; and freedom of expression/information as a crucial element of a democracy. The report noted that the norms and political values of the Commonwealth compel the association to act to promote tolerance in member countries and the report made recommendations for achieving this goal.

Rights Do Matter (1995)

Rights Do Matter explored two themes: freedom of expression and the need for major reform in prisons. The report placed this discussion in the context of the transition from authoritarian to democratic political orders and the economic transition from planned to market economies.

\section{Act Right Now (1993)}

Act Right Now was an assessment of the progress of human rights in Commonwealth countries since the Harare Declaration and was made with reference to the United Nations World Conference on Human Rights in Vienna in June 1993. It called for the Commonwealth to play a lead role in supporting the long, complex process of moving towards real democracy in transitional countries.

\section{Put Our World to Rights (1991)}

Put Our World to Rights was the first independent overview of the status of human rights in the Commonwealth. It provides practical guidance on how to use international machinery for redress. 


\section{CHRI PROGRAMMES}

CHRI's work is based on the belief that for human rights, genuine democracy and development to become a reality in people's lives, there must be high standards and functional mechanisms for accountability and participation within the Commonwealth and its member countries. Accordingly, in addition to a broad human rights advocacy programme, CHRI advocates access to information and access to justice. It does this through research, publications, workshops, information dissemination and advocacy.

\section{HUMAN RIGHTS ADVOCACY}

CHRI makes regular submissions to official Commonwealth bodies and member governments. From time to time CHRI conducts fact finding missions and since 1995, has sent missions to Nigeria, Zambia, Fiji Islands and Sierra Leone. CHRI also coordinates the Commonwealth Human Rights Network, which brings together diverse groups to build their collective power to advocate for human rights. CHRI's Media Unit also ensures that human rights issues are in the public consciousness.

\section{ACCESS TO INFORMATION}

CHRI catalyses civil society and governments to take action, acts as a hub of technical expertise in support of strong legislation, and assists partners with implementation of good practice. CHRI works collaboratively with local groups and officials, building government and civil society capacity as well as advocating with policy makers. CHRI is active in South Asia, most recently supporting the successful campaign for a national law in India; provides legal drafting support and inputs in Africa; and in the Pacific, works with regional and national organisations to catalyse interest in access legislation.

\section{ACCESS TO JUSTICE}

\section{Police Reforms:}

In too many countries the police are seen as oppressive instruments of state rather than as protectors of citizens' rights, leading to widespread rights violations and denial of justice. CHRI promotes systemic reform so that police act as upholders of the rule of law rather than as instruments of the current regime. In India, CHRI's programme aims at mobilising public support for police reform. In East Africa and Ghana, CHRI is examining police accountability issues and political interference.

\section{Prison Reforms:}

The closed nature of prisons makes them prime centres of violations. CHRI aims to open up prisons to public scrutiny by ensuring that the near defunct lay visiting system is revived.

\section{Judicial Education:}

CHRI facilitates judicial exchanges focusing on access to justice for the most vulnerable. Participating judges get a rare opportunity to hear from activists and experts, focus on pressing issues specific to their region and familiarize themselves with recent legal and procedural, as well as social and scientific, developments relevant to their judicial work. The work was begun with INTERIGHTS some years ago. CHRI now works independently to orient lower court judges on human rights in the administration of justice. 
In the international stampede to cooperate in countering terrorism, many Commonwealth countries have enacted new anti-terrorism laws or strengthened existing security provisions. Where police are the frontline actors in these responses, states have enhanced police discretion, increased police powers and diminished police accountability even as they have reduced traditional protections of due process. This trend has created an environment conducive to human rights violations. Already, abusive policing is rife in the Commonwealth. These harsher measures add to the distance between police and society, alienate communities and undermine policing at a time it most needs publicsupport.

The Commonwealth is bound by its commitment to democracy, human rights and the rule of law. The answer to terrorism lies in laws that are narrowly cast, crystal clear and firmly based on the principles of human rights, to ensure policing better protects people's rights and freedoms. Without this, counter-terrorism can only be counter-productive. True security is human rights protection.

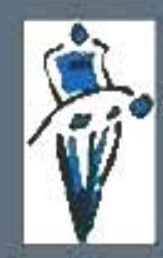

